\title{
Opole (Poland) - a key locality for middle Miocene terrestrial mollusc faunas
}

\author{
MATHIAS HARZHAUSER \& THOMAS A. NEUBAUER
}

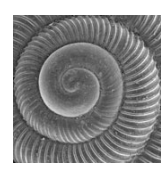

\begin{abstract}
We describe an early middle Miocene (late Langhian) terrestrial mollusc fauna from Nowa Wieś Królewska at Opole in Silesia (Poland). This survey is based on the rich collection stored in the Natural History Museum in Vienna and represents the first revision of this classical fauna. The assemblage is extraordinarily diverse and comprises 82 gastropod species and one bivalve species. About $56 \%$ of the taxa are known so far only from Nowa Wieś Królewska, emphasizing the preeminent position of this fauna within the European Neogene. The fauna reveals taxonomic affinities with early and early middle Miocene faunas. Stratigraphic overlap of several species and genera would suggest a correlation with the mammal biozone MN 5; integrating mammal data, however, indicates correlation with the biozone MN 6. This discrepancy is explained best by the lack of other adequately revised European MN 6 mollusc faunas. Consequently, the fauna from Nowa Wieś Królewska is proposed here as type of a MN 6 mollusc fauna in Central Europe. As such, this fauna represents the best-documented terrestrial mollusc fauna from the late Miocene Climate Optimum. Semi-quantitative abundance data of the terrestrial gastropods suggests the presence of ephemeral ponds and fens that formed on Cretaceous limestones, surrounded by forested environments with leaf litter and dead wood. Occidentina gen. nov., Mennoia gen. nov., Neubertella gen. nov. and Eurocystina gen. nov. are described as new genera. Martinietta kadolskyi sp. nov., Carychium stworzewiczae sp. nov., Gastrocopta (Albinula) polonica sp. nov., Leiostyla piserai sp. nov., Vertigo antipygmaea sp. nov., Mennoia sculpturata sp. nov., Neubertella pulchra sp. nov., Aegopinella depressula sp. nov., Eurocystina nordsiecki sp. nov. and Vitrea angustaeumbilicata sp. nov. are introduced as new species. $\bullet$ Key words: terrestrial gastropods, freshwater gastropods, bivalve, taxonomy, systematics, Badenian, Langhian.
\end{abstract}

HARZHAUSER, M. \& Neubauer, T.A. 2018. Opole (Poland) - a key locality for middle Miocene terrestrial mollusc faunas. Bulletin of Geosciences 93(1), 71-146 (14 figures, 1 table). Czech Geological Survey, Prague. ISSN 1214-1119. Manuscript received September 1, 2017; accepted in revised form January 8, 2018; published online March 31, 2018; issued March 31, 2018.

Mathias Harzhauser, Geological-Paleontological Department, Natural History Museum Vienna, 1010 Vienna, Austria; mathias.harzhauser@nhm-wien.ac.at - Thomas A. Neubauer, Department of Animal Ecology \& Systematics, Justus Liebig University, Heinrich-Buff-Ring 26-32 IFZ, 35392 Giessen, Germany, and Naturalis Biodiversity Centre, P.O. Box 9517, 2300 RA Leiden, The Netherlands; thomas.a.neubauer@allzool.bio.uni-giessen.de

The mollusc fauna from Nowa Wieś Królewska at Opole (Fig. 1) was detected during the early $20^{\text {th }}$ century, when this part of Silesia belonged to the German Empire. Oppeln, which is the old German name for Opole, was mainly known to geologists for the Cretaceous deposits exploited in the quarry of the "Grundmann'sche Cementfabrik" at Königlich Neudorf (= Nowa Wieś Królewska). Around 1901, fissure fills in the Cretaceous deposits, exposing about 5 to 9 metres of clayey marls, were recognized to contain Miocene gastropod shells; in addition, vertebrate remains were found in lignites within the marls (Wegner 1908).

The analysis of the terrestrial mollusc fauna started with a fierce controversy between R. Michael and A. Andreae. Material became available simultaneously to both scientists and both presented first results in 1902 (Andreae 1902a; Michael 1902). Soon, more data on fauna and geology were published by both of them (Andreae 1902b, 1903, 1904a, b; Michael 1904). The descriptions of Andreae (1902a, b, 1904a) were partly accompanied by rather idealized drawings and only very few photographs. Therefore, the status of several species - and especially of those mentioned without illustration - remained difficult to evaluate for subsequent authors, such as Wenz (1923-1930). Nevertheless, Oppeln was established as one of the key localities of Cenozoic European terrestrial mollusc faunas for its high diversity and good perservation. In the following, many taxonomic papers described, revised or discussed species from Opole (e.g. Pfeffer 1930; Falkner 1974; Schlickum \& Strauch 1975; Strauch 1977; 
Schlickum 1979a; Nordsieck 1981a, 2014; Boeters et al. 1989; Hausdorf 1995; Stworzewicz 1995, 1999a, b; Schnabel 2006; Kadolsky et al. 2016). Even more papers provided taxonomic opinions on taxa supposedly also present in the Opole fauna and/or listed occurrences from Nowa Wieś Królewska in chresonymy lists (e.g. Harzhauser et al. 2014a, b, 2015; Neubauer et al. 2017). The last attempt to summarize the Opole fauna was presented by Höltke et al. (2016), but this list only repeats data from Wenz (1923-1930) and neglects nearly all later papers and revisions.

Gaining an overview of this maze of contributions and taxonomic opinions has been proven difficult even for the specialist. Mollusc faunas are an important tool for terrestrial biostratigraphy (Nordsieck 1982; Harzhauser et al. 2015). In contrast to the aquatic realm (Neubauer et al. 2015), terrestrial biogeographic patterns of the European Neogene are still poorly understood (Höltke et al. 2016). Therefore, it is desirable to survey and review the mollusc assemblages of key localities, such as Nowa Wieś Królewska, as already performed for Tuchořice (Czech Republic), Rein (Austria), Eichkogel (Austria), Moncucco Torinese (Italy) and Vračević (Serbia) by Harzhauser \& Binder (2004), Harzhauser et al. (2014a, b, 2015) and Neubauer et al. (2017) and for numerous Miocene localities in S Germany by Salvador (2014), Salvador \& Rasser (2014, 2016a, b) and Salvador et al. (2015, 2016a, b, c, 2017). Finally, biostratigraphical and paleoecological interpretations based on the present mollusc fauna are also of interest for vertebrate paleontologists because Nowa Wieś Królewska is an important locality for Miocene vertebrates (e.g. Andreae 1904a; Wegner 1908, 1913; Ryziewicz 1961; Kowalski 1967, 1994; Młynarski et al. 1982; Fahlbusch 1989; Korotkievich \& Sulimski 1990; Szyndlar 1991).

\section{Geographic setting and stratigraphy}

The locality Nowa Wieś Królewska was a cement quarry ("Grundmann'sche Cementfabrik"), which has been abandoned already during the early $20^{\text {th }}$ century. The area is now part of Opole and lies about four kilometres southeast of the city center on the right bank of the river Oder. No precise age data are available for the non-marine deposits. Previous investigations, variably based on mammals, reptiles and molluscs, all conclude on a middle Miocene age. The earliest comprehensive assessment of the rich mammal fauna of Nowa Wieś Królewska interpreted the deposits as being of Sarmatian age (Wegner 1913, Kowalski 1967). Based on the clausiliid fauna, Nordsieck (1982) revised this classification and tentatively assigned the deposits to the Neogene mammal biozones MN 6-7 (see also Kadolsky et al. 2016, Neubauer et al. 2017). The mammal fauna was later attributed to zone MN $7+8$ by De Bruijn et al. (1992), which was followed by studies on terrestrial molluscs (Stworzewicz 1999a, b) and reptiles (Ivanov 2001) (see also Daxner-Höck 2010). Other investigations on mammal remains from nearby localities in Opole yielded slightly different age models (MN 6 and MN 7, respectively; Kowalski \& Rzebik-Kowalska 2002).

\section{Material}

Only parts of the collections of Andreae (1902a, b, 1904a) are still preserved in the Roemer- und Pelizaeus-Museum in Hildesheim (Germany). Therefore, we base our survey on the rich material in the collection of the Natural History Museum in Vienna. The specimens were collected in the early $20^{\text {th }}$ century by Oskar Troll-Obergfell, who donated his private collection to the Natural History Museum Vienna (NHMW) and the Bavarian State Collection for Palaeontology in Munich. Troll-Obergfell used bulk-samples, which were washed, sieved and picked. Therefore, based on a total amount of more than 3000 specimens, the specimen numbers per species might be used as very rough estimate of the quantitative composition of the assemblages. This method, however, caused a bias against large-sized specimens, such as large helicids, which are mainly represented as fragments.

\section{Systematic palaeontology}

The systematic arrangement of the Stylommatophora follows Nordsieck (2017); other taxa are arranged according to MolluscaBase (http://www.molluscabase.org). We use these schemes uncritically, because discussions on suprageneric systematics and taxonomy are not focus of this paper.

Class Gastropoda Cuvier, 1795

Subclass Neritimorpha Golikov \& Starobogatov, 1975

Order Cycloneritimorpha Frýda, 1998

Superfamily Hydrocenoidea Troschel, 1857

Family Hydrocenidae Troschel, 1857

\section{Genus Hydrocena Küster, 1844}

Type species. - Paludina sirkii Küster, 1844 [currently considered a junior synonym of Hydrocena cattaroensis (L. Pfeiffer, 1841)]; by monotypy. Recent, SE Europe.

Hydrocena trolli Schlickum, 1979

Figure 2A-D

1902b Pseudamnicola helicella (Al. Br.). - Andreae, p. 5 (non Litorinella helicella Sandberger, 1859). 


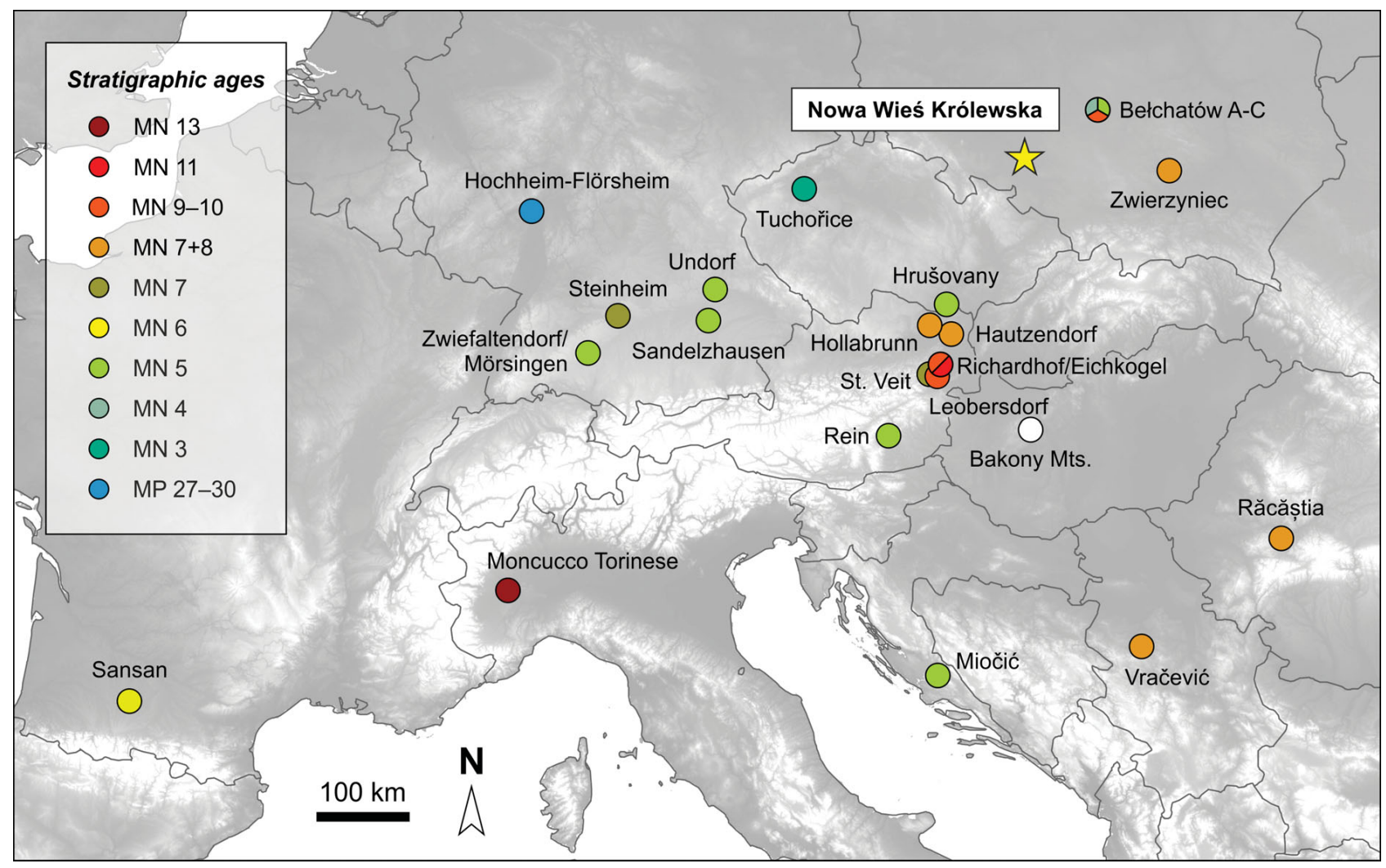

Figure 1. Geographical overview of the studied locality Nowa Wieś Królewska at Opole, along with localities with late Oligocene-late Miocene terrestrial gastropod faunas mentioned in the text. Coloration follows the mammal Neogene/Paleogene biozones. Coloration is omitted for the Bakony Mts., which summarize several localities with ages ranging from MN 3b to MN 7+8 (Ottnangian to Sarmatian).

1904a Pseudamnicola helicella (Al. Braun). - Andreae, p. 17 (non Sandberger, 1859).

1904b Pseudamnicola helicella (Al. Braun). - Andreae, p. 252 (non Sandberger, 1859).

1926 Amnicola (Amnicola) cf. helicella (Sandberger). Wenz, p. 2064.

*1979a Hydrocena (Hydrocena) trolli n. sp.; Schlickum, p. 71, figs 3-4.

2016a trolli Schlickum, 1979, Hydrocena (Hydrocena). Salvador et al., p. 38, pl. 9, fig. 14.

Material. - 254 specimens (NHMW 2017/0092/0001).

Dimensions. - Diameter: $2.2 \mathrm{~mm}$, height: $2.6 \mathrm{~mm}$ (Fig. 2A, D); diameter: $2.1 \mathrm{~mm}$, height: $2.5 \mathrm{~mm}$ (Fig. 2B); diameter: $1.7 \mathrm{~mm}$, height: $2.4 \mathrm{~mm}$ (Fig. 2C).

Description. - Small, stout conical shell comprising three strongly convex teleoconch whorls with deeply incised suture. Protoconch consisting of 0.5 bulbous, smooth whorls of $450 \mu \mathrm{m}$ diameter and $300 \mu \mathrm{m}$ height. Transition into teleoconch marked by weak rim and onset of delicate crisscross sculpture on first teleoconch whorl. Later whorls smooth aside from delicate, prosocline growth lines and weak spiral sculpture where uppermost shell surface is eroded. Peristome thin; aperture semi-circular with moderately broad inner lip, partly covering the wide and open umbilicus.

Remarks. - Andreae (1902b) mentioned more than 100 specimens of Pseudamnicola helicella (Sandberger). Already Andreae (1902b) emphasized that his specimens differ from the Oligocene shells from the Mainz Basin in its larger size. Wenz (1926) doubted that the middle Miocene species from Opole are conspecific with it at all, but suggested a relationship with the early middle Miocene Bania gobanzi (Frauenfeld, 1864), from the Rein Basin in Styria, or Bania convexa (Sandberger, 1875), from the early/middle Miocene of Germany (see Neubauer et al. 2013 for discussion on generic placement of B. gobanzi). In fact, Andreae (1902b) misidentified the supposed hydrobiid with the morphologically similar neritimorph Hydrocena, for which Schlickum (1979a) introduced H. trolli. This species is among the most frequent species in the Opole assemblage. Extant Hydrocena cattaroensis (L. Pfeiffer, 1841) clearly differs from the Miocene species in its much larger last whorl. It prefers rocks and humid habitats (Welter-Schultes 2012), which might also have been the 
case for H. trolli. Hydrocena moncuccoensis Harzhauser, Neubauer \& Esu in Harzhauser et al. (2015), from the Messinian of Italy, is comparable in shape and protoconch features but differs in its prominent spiral sculpture.

Occurrence. - Only known from Nowa Wieś Królewska at Opole (Poland).

Subclass Caenogastropoda Cox, 1960

Order Architaenioglossa Haller, 1890

Superfamily Cyclophoroidea Gray, 1847

Family Craspedopomatidae Kobelt \& Möllendorff, 1898

\section{Genus Craspedopoma L. Pfeiffer, 1847}

Type species. - Cyclostoma lucidum Lowe, 1831; by monotypy. Recent, Madeira.

\section{Craspedopoma sp.}

Figure 2E-G

1902a Craspedopoma leptopomoides (Reuss). - Andreae, p. 7 (non Valvata leptopomoides Reuss, 1868).

1902b Craspedopoma leptopomoides (Rss.). - Andreae, p. 22 (non Reuss, 1868).

1903 Craspedopoma leptopomoides Rss. - Andreae, p. 541 (non Reuss, 1868).

1904 Craspedopoma leptopomoides Reuss. - Michael, p. 380 (non Reuss, 1868).

1904a Craspedopoma leptopomoides (Reuss). - Andreae, p. 17 (non Reuss, 1868).

2016 Bolania leptopomoides. - Höltke et al., p. 235 (non Reuss, 1968).

Material. - 22 specimens (NHMW 2017/0092/0002).

Dimensions. - Diameter: $3.8 \mathrm{~mm}$, height: $3.0 \mathrm{~mm}$ (aperture missing) (Fig. 2E); diameter: $3.9 \mathrm{~mm}$, height: $3.6 \mathrm{~mm}$ (apex missing) (Fig. 2F).

Description. - Small turbinate shell; protoconch high, slender, consisting of 1.7 smooth whorls of $1.2 \mathrm{~mm}$ diameter, with low, slightly sunken initial part. Transition into teleoconch indistinct, indicated mainly by onset of irregularly spaced, coarse, prosocline growth lines and distinct increase of convexity of whorls. Teleoconch consisting of two strongly convex, tube-like whorls, rapidly increasing in width; suture deeply incised. Aperture detached from base, circular with faintly flaring peristome and very weak and shallow internal groove close behind peristome. Umbilicus moderately wide.

Remarks. - Since the first identification by Andreae (1902a) this species has always been treated as Craspedo- poma leptopomoides (Reuss, 1868). The Polish specimens differ from that species in its narrower, higher protoconch and the sunken initial part (see Craspedopoma leptopomoides in Harzhauser et al. 2014a). In addition, the last whorl of Craspedopoma sp. is broader and more evenly convex. Craspedopoma conoidale (Michaud, 1855), from the late Miocene and early Pliocene of France and Italy, differs also in its more slender outline (see Harzhauser et al. 2015). Procyclotopsis? glazeki (Stworzewicz, 1995), from the early Miocene of Poland, is reminiscent of the species from Opole, but differs in its smaller size, the broader last whorl and the characteristic spiral sculpture on the teleoconch. The specimens from Nowa Wieś Królewska represent most probably a new, yet unnamed species. Due to the fragmentary preservation, however, we refrain from establishing it formally as new species.

Occurrence. - Only known from Nowa Wieś Królewska at Opole (Poland).

Family Diplommatinidae L. Pfeiffer, 1857

\section{Genus Occidentina gen. nov.}

Type species. - Occidentina martensi (Andreae, 1902).

Etymology. - Referring to the Occident (from Latin: occidens $=$ sunset, West); in respect to the western distribution of this Diplommatinidae.

Diagnosis. - Small, elongate pupoid, sinistrally coiled shells of 4.5 strongly convex teleoconch whorls with deeply incised suture. Protoconch comprising $<1$ whorl; initial part smooth, dome-shaped, later protoconch becoming successively more pitted. Transition into teleoconch indicated by onset of prominent, thin, moderately wide-spaced axial ribs. Axial ribs slightly opisthocyrt and lamellose; c. 20 on last whorl. Interspaces between ribs covered by densely spaced, delicate, granulose spiral threads. Last whorl slightly pulled in, terminating in subcentral, subcircular aperture with moderately flaring peristome. Umbilicus strongly narrowed by inner lip. Narrow but prominent columellar denticle appears close to base, deep inside aperture in penultimate whorl, rarely continuing as very weak central swelling on columella close to aperture. Weak, sharp parietal lamella inside third teleoconch whorl; parietal lamella appears earlier than columellar denticle; the two structures do not co-occur at same growth stage; rest of inner shell smooth.

Remarks. - The type species of this new genus has traditionally been placed in Palaina Semper, 1865 (e.g. Andreae 1904a, Wenz 1923, Stworzewicz 1995). Diplommatina macgillivrayi L. Pfeiffer, 1854, designated as the type spe- 
cies of Palaina by Iredale (1944), is an extant species collected from Lord Howe Island in Australia. Diplommatinidae are generally widely distributed in eastern and southern Asia, northern Australia, the Pacific islands and South America (Páll-Gergely et al. 2017). Similarly, Palaina species have been described from localities throughout the western Pacific, Australasia and Southeast Asia (Rundell 2008). Convergent shell morphologies, however, are frequent within Diplommatinidae, which hampers clear generic identifications (Páll-Gergely et al. 2017). Molecular phylogenies showed that "Palaina" is non-monophyletic (Rundell 2008, Webster et al. 2012). Nevertheless, all phylogenetic studies demonstrated that "Palaina", along with other Diplommatinidae genera like Hungerfordia and Opisthostoma, belongs to geologically young (Miocene or younger) Indo-Pacific and Pacific radiations (Rundell 2008, Webster et al. 2012). Neubert \& Bouchet (2015) even discuss a restriction of Palaina s.s. to the Lord Howe and Palau radiations and assume that the species from Fiji that have been attributed to the genus might represent a radiation on its own. Therefore, in respect to paleobiogeography and stratigraphy, a close relationship of the middle Miocene European species with the Pacific Palaina is highly unlikely. Despite the striking morphological convergence, a separation of Occidentina from Palaina is morphologically supported by the presence of a parietal denticle, which is unknown from Palaina (see diagnosis in Neubert \& Bouchet 2015).

Other species. - Type species only. The placement of the extant Diplommatina amurensis Mousson, 1887, from the Vladivostok region, in Palaina as proposed by Kantor et al. (2010) is biogeographically unlikely. We have not studied material of the Russian species, which is why a potential relationship with Occidentina remains unclear.

Occurrence. - The new genus is only known from the middle Miocene of Central Europe.

Occidentina martensi (Andreae, 1902) comb. nov. Figure $2 \mathrm{H}-\mathrm{L}$

*1902b Adelopoma martensi n. sp.; Andreae, p. 17, text-fig. 11.

1903 Adelopoma Martensi n. sp. - Andreae, p. 541.

1904a Palaina (Adelopoma) martensi m. - Andreae, p. 17.

1904b Palaina (Adelopoma) martensi m. - Andreae, p. 252.

1923 Palaina (Palaina) martensi (Andreae). - Wenz, p. 1764.

1944 Palaina Martensi Andreae. - Troll-Obergfell, p. 384.

1967 Palaina (Palaina) martensi (Andreae). - Schütt, p. 200, fig. 1.
1995 Palaina martensi (Andreae 1902). - Stworzewicz, p. 24, fig. 8 .

2006 Palaina martensi (Andreae), 1902. - Kókay, p. 2, figs $14,15$.

2016 Palaina martensi. - Höltke et al., p. 235.

Material. - 88 specimens (NHMW 2017/0092/0003).

Dimensions. - Diameter: $1.1 \mathrm{~mm}$, height: $2.2 \mathrm{~mm}$ (Fig. 2H); diameter: $1.0 \mathrm{~mm}$, height: $2.2 \mathrm{~mm}$ (Fig. 2I).

Description. - As above for genus.

Remarks. - The microsculpture of delicate spiral threads between the axial ribs has not been described so far for this species but is found among Diplommatinidae (e.g. Diplommatina insularis Tongkerd, Sutcharit \& Panha, 2013). Andreae (1902b) placed this species originally in Adelopoma Doering, 1885 and transferred it to Palaina in 1904. In the same year, Kobelt (1904) recombined the extant Diplommatina (Diancta) martensi H. Adams, 1866 as Palaina martensi, thus producing a secondary homonym. As the extant species from Fiji and Viti Levu is now placed in Diancta Martens, 1864 (see Neubert \& Bouchet 2015), matching the original intention of H. Adams (1866), and the Miocene species is placed in Occidentina, no homonymy is given.

Distribution. - Aside from Nowa Wieś Królewska at Opole (Poland), this species was also reported from the Badenian of St. Veit an der Triesting in the Vienna Basin in Austria (Troll-Obergfell 1944), the Sarmatian of Hollabrunn (Schütt 1967) and Oberdorf at Weiz in Styria (Winkler-Hermaden 1952) in Austria, the Sarmatian of Várpalota in Hungary (Kókay 2006) and the early Tortonian of Bełchatów A (Poland, MN 9) (Stworzewicz 1995).

Family Aciculidae Gray, 1850

\section{Genus Acicula Hartmann, 1821}

Type species. - Bulimus lineatus Draparnaud, 1801; by monotypy. Recent, France.

\section{Acicula lineata (Draparnaud, 1801)}

Figure 2M-O

*1801 B.[ulimus] lineatus; Draparnaud, p. 67.

1902b Acme limbata Rss. - Andreae, p. 24 (non Acicula limbata Reuss, 1861).

1903 Acme limbata Rss. - Andreae, p. 541 (non Reuss, 1861).

1904a Acme limbata Reuss. - Andreae, p. 17 (non Reuss, 1861). 
1904b Acme limbata Reuss. - Andreae, p. 252 (non Reuss, 1861).

1989 Acicula lineata lineata (Draparnaud, 1805). - Boeters et al., p. 60, figs 42, 62-62, 68 (cum syn.).

2012 Acicula lineata (Draparnaud, 1901). Welter-Schultes, p. 75, unnumbered text-fig.

2016 Acicula limbata. - Höltke et al., p. 235 (non Reuss, 1861).

Material. - 36 specimens (NHMW 2017/0092/0004).

Dimensions. - Diameter: $1.1 \mathrm{~mm}$, height: $3.1 \mathrm{~mm}$ (Fig. 2N).

Remarks. - This species was misidentified as Acicula limbata Reuss, 1861 by Andreae (1902b, 1904a, b) and Höltke et al. (2016). Acicula limbata was originally described from the early Miocene of Tuchořice and differs from $A$. $l i$ neata in its more cylindrical outline, the higher last whorl, the less convex spire whorls and the less prominent and wider spaced axial grooves.

Occurrence. - Middle Miocene of Nowa Wieś Królewska at Opole (Poland), Pliocene of Sessenheim (France), Pleistocene of France (Boeters et al. 1989); extant representatives have a central European distribution (see Boeters et al. 1989 and Welter-Schultes 2012 for details).

\section{Acicula isseli (Flach, 1889)}

Figure 2P-R

*1889 Acme isseli n. sp.; Flach, p. 72, fig. 7.

1891 Acme Isselii Flach. - Flach, p. 59, pl. 3, figs 9a, b.

1976 Acicula (Acicula) isselii (Flach). - Zilch, p. 126, pl. 12, fig. 9.

1989 Acicula isselii (Flach, 1889). - Boeters et al., p. 51, fig. 40.

Material. - 10 specimens (NHMW 2017/0092/0005).

Dimensions. - Largest specimen: diameter: $0.75 \mathrm{~mm}$, height: $1.8 \mathrm{~mm}$.

Description. - Tiny, fragile, subcylindrical shell of five whorls. Protoconch low dome-shaped with moderately convex whorl and incised suture. Teleoconch whorls slowly but steadily increasing in height, passing from distinctly convex to nearly straight-sided on last whorl. Max- imum convexity at midwhorl on spire whorls but in lower third of last whorl. Suture distinct, without subsutural spiral thread. Sculpture consisting of irregularly spaced, prosocline axial grooves persisting also on moderately convex base. Aperture narrowly U-shaped; outer lip thin, basal lip weakly widening; inner lip narrow, slightly reflected over narrow chink-like umbilicus; no parietal lip or callus.

Remarks. - This species is reminiscent of Acicula fusca frici (Flach, 1889), from the Burdigalian of Tuchořice, but differs in its even smaller size, the more cylindrical and slender outline and the convex early teleoconch whorls.

Occurrence. - Originally described from the early/middle Miocene of Undorf in Germany (MN 5); the occurrence from Nowa Wieś Królewska at Opole (Poland) was already documented by Boeters et al. (1989). Its occurrence in the middle Miocene of Bełchatów reported by Stworzewicz \& Sołtys (1996) as Acicula cf. isseli is doubtful in respect to the conical outline of the Bełchatów specimen.

\section{Genus Platyla Moquin-Tandon, 1856}

Type species. - Acme dupuyi Paladilhe, 1868; by subsequent designation by Welter-Schultes (2012). Recent, France.

\section{Platyla callosiuscula (Andreae, 1904)}

Figure 3A, B

1902b Acme callosa Böttg. - Andreae, p. 24 (non Acicula callosa O. Boettger, 1870).

1903 [Acme] callosa Böttg. - Andreae, p. 541 (non O. Boettger, 1870).

*1904a Acme callosiuscula n. sp.; Andreae, p. 14, text-fig. 13.

1904b Acme callosiuscula n. sp. - Andreae, p. 252.

1923 Acme (Acme) callosiuscula Andreae. - Wenz, p. 1852.

1944 Acme callosiuscula Andreae. - Troll-Obergfell, p. 384.

2008 Platyla callosiuscula (Andreae, 1904). - Harzhauser et al., p. 48, figs 4.1-2.

2016 Acicula callosiuscula. - Höltke et al., p. 235.

Material. - 85 specimens (NHMW 2017/0092/0006).

Dimensions. - Diameter: $0.95 \mathrm{~mm}$, height: $2.2 \mathrm{~mm}$ (Fig. 3A); diameter: $1.05 \mathrm{~mm}$, height: $2.3 \mathrm{~mm}$ (Fig. 3B).

Figure 2. Hydrocenidae, Craspedopomatidae, Diplommatinidae and Aciculidae. • A, B, C, D - Hydrocena trolli Schlickum, 1979 (NHMW 2017/0092/0001); D - protoconch of A. • E, F, G - Craspedopoma sp. (NHMW 2017/0092/0002) • H, I, J, K, L - Occidentina martensi (Andreae, 1902) (NHMW 2017/0092/0003); K - protoconch of I. • M, N, O - Acicula lineata (Draparnaud, 1801) (NHMW 2017/0092/0004). P, Q-R - Acicula isseli (Flach, 1889) (NHMW 2017/0092/0005). 


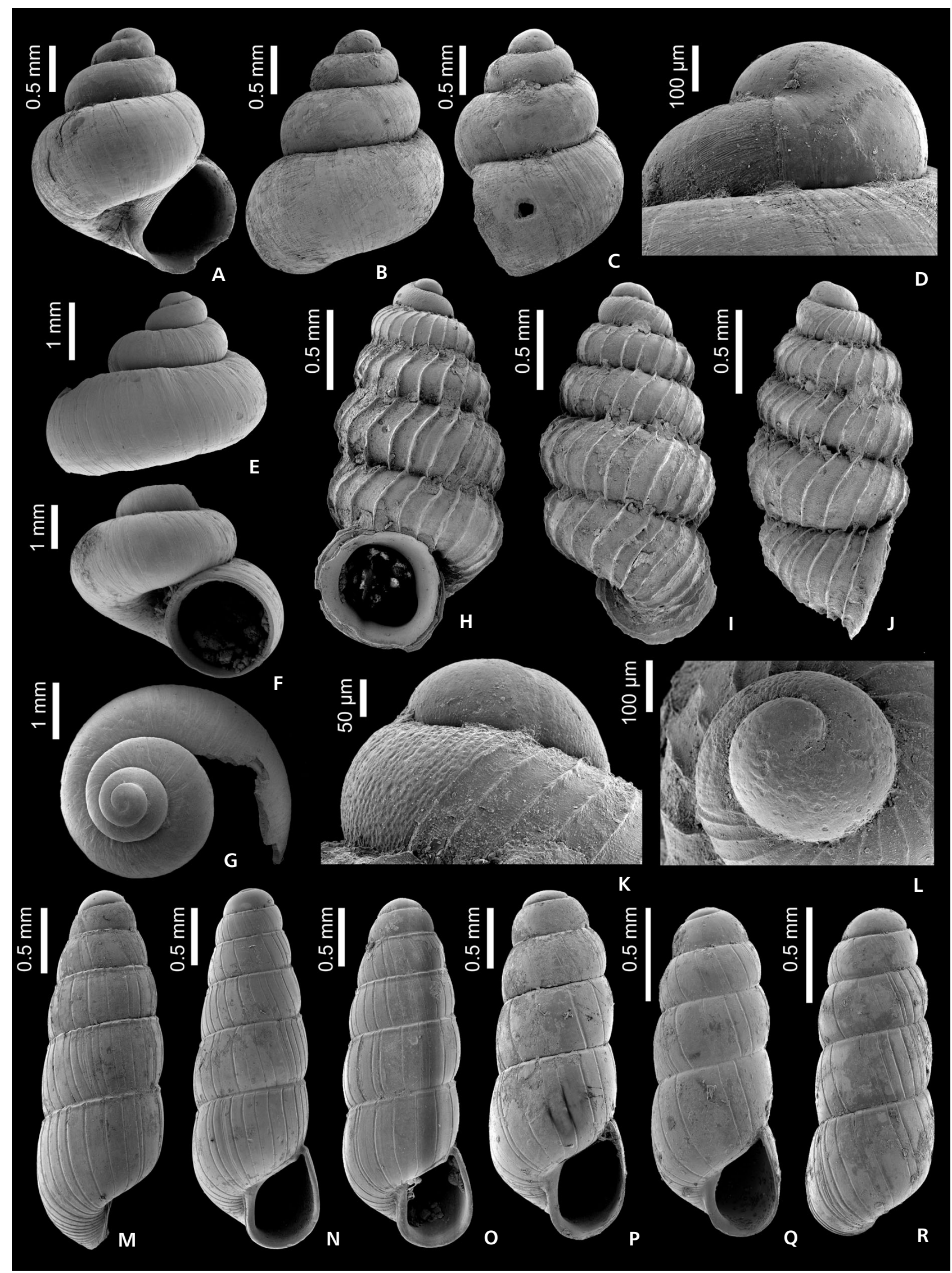


Description. - Small conical-fusiform shell of 4.5-5 whorls. Protoconch low dome-shaped, smooth. Weak angulation appears on protoconch whorl, separating narrow, flat subsutural band along upper suture. Transition into teleoconch indistinct. Teleoconch whorls moderately convex, suture distinct, usually accompanied by faint angulation. Surface smooth aside from few, irregularly spaced, very weak axial grooves. Last whorl rapidly contracting over marked convexity into straight-sided, shallow base. Aperture drop-shaped, moderately wide without dentition; prominent, weakly reflected external peristomal varix. Especially basal part of varix is usually split into prominent basal lip and protruding, reflected rim. Umbilicus reduced to narrow slit.

Remarks. - Platyla callosiuscula (Andreae, 1904) was synonymized by Boeters et al. (1989) with the Oligocene to early Miocene Platyla subfusca (Flach, 1889). The latter species, as described by Harzhauser et al. (2014a) from the early Miocene of Tuchořice in Czech Republic, can be clearly separated from the present species. With $2.3 \mathrm{~mm}$ height, Platyla callosiuscula is distinctly smaller as $P$. subfusca, which attains about $2.9 \mathrm{~mm}$ in height. The shells of $P$. callosiuscula are much stouter and the upper suture of the protoconch whorl is accompanied by a narrow angulation, which is absent in P. subfusca. Moreover, the prominent basal rim of the peristomal varix is weaker in $P$. subfusca.

Occurrence. - Aside from Nowa Wieś Królewska at Opole (Poland), the species was also described from the Badenian of St. Veit an der Triesting in the Vienna Basin (Austria) (Troll-Obergfell, 1944) and the Sarmatian of Gratkorn (Austria) (Harzhauser et al. 2008). The Sarmatian specimens from Zwiefaltendorf in S. Germany described by Schlickum (1976) were transferred to Platyla subfusca (Flach, 1889) by Boeters et al. (1989). The Sarmatian occurrence from Hollabrunn in Lower Austria described by Schütt (1967) might rather represent Platyla polita (Boeters et al. 1989, p. 152).

\section{Platyla falkneri Boeters, Gittenberger \& Subai, 1989} Figure 3C, D

*1989 Platyla falkneri spec. nov.; Boeters et al., p. 115, figs $94,113,116$.

Material. - 12 aperture fragments and 6 spire fragments (NHMW 2017/0092/0007).

Dimensions. - Last whorl diameter: $1.5 \mathrm{~mm}$ (Fig. 3D); last whorl diameter $1.6 \mathrm{~mm}$ (Fig. 3C).

Remarks. - The species was described in detail by Boeters et al. (1989); the aperture of P. falkneri is highly reminiscent of Platyla callosiuscula (Andreae, 1904) and at first sight the specimens could be mistaken for this species. As already pointed out by Boeters et al. (1989), however, the much larger size of $P$. falkneri allows a clear separation. Both species show little variability in size without any intermediate forms. In addition, the spire of $P$. falkneri is more conical.

Occurrence. - Only known from Nowa Wieś Królewska at Opole (Poland).

\section{Genus Renea Nevill, 1880}

Type species. - Renea bourguignatiana Nevill, 1880; by original designation. Recent, France.

\section{Renea pretiosa (Andreae, 1904)}

Figure $3 \mathrm{E}-\mathrm{G}$

*1904a Pseudotruncatella pretiosa n. sp.; Andreae, p. 16, text-fig. 14.

1904b Pseudotruncatella nov. gen. pretiosa n. sp. - Andreae, p. 252.

1923 Renea (Pleuracme) pretiosa (Andreae). - Wenz, p. 1860.

1967 Renea (Pleuracme) pretiosa (Andreae, 1904). Schütt, p. 203.

1978 Pseudotruncatella microceras (A. Braun) Sandberger. - Gozhik \& Prysjazhnjuk, p. 65, pl. 2, fig. 2 (non Bulimus microceras Braun in Walchner, 1851).

1988 Renea pretiosa (Andreae). - Stworzewicz \& Szynkiewicz, p. 657.

1989 Renea pretiosa (Andreae). - Boeters et al., p. 199, figs 202, 212.

1996 Renea pretiosa (Andreae 1904). - Stworzewicz \& Sołtys, p. 73, figs 11, 12.

2016 Pseudotruncatella microceras. - Höltke et al., p. 235 (non Braun in Walchner, 1851).

2016 Renea pretiosa. - Höltke et al., p. 235.

Material. - 6 specimens (NHMW 2017/0092/0008).

Dimensions. - Diameter: $0.8 \mathrm{~mm}$, height: $2.1 \mathrm{~mm}$ (Fig. 3G); diameter: $0.7 \mathrm{~mm}$, height: $1.8 \mathrm{~mm}$ (Fig. 3F); diameter: $0.8 \mathrm{~mm}$, height: $1.8 \mathrm{~mm}$ (Fig. $3 \mathrm{E}$ ).

Remarks. - This small Renea species was discussed in detail by Boeters et al. (1989) and Stworzewicz \& Sołtys (1996). As already recognized by Stworzewicz \& Sołtys (1996) it is slightly variable in the degree of its slenderness. Nevertheless, it is always distinctly broader than the Oligocene Renea microceras (Braun in Walchner, 1851), which was erroneously reported from Opole by Höltke et al. 
(2016) as Pseudotruncatella microceras. Indeed, Andreae (1904a) referred to Renea microceras when introducing Pseudotruncatella as new genus, but he did not describe the species from Opole. According to Boeters et al. (1989), Pseudotruncatella is a subjective junior synonym of $R e$ nea, a taxon that was probably unknown to Andreae $(1904 a, b)$ as he did not refer to this genus.

Occurrence. - This species was originally described from Nowa Wieś Królewska at Opole (Poland) and later also reported from the early or early middle Miocene of Bełchatów in Poland and the early Sarmatian of Ukraine (Stworzewicz \& Sołtys 1996).

Order Littorinimorpha Golikov \& Starobogatov, 1975

Superfamily Truncatelloidea Gray, 1840

Family Hydrobiidae Stimpson, 1865

\section{Genus Martinietta Schlickum, 1974}

Type species. - Bythinella striata K. Fischer \& Wenz, 1916; by typification of replaced name. Early Miocene, Germany.

\section{Martinietta kadolskyi sp. nov.}

Figure $3 \mathrm{H}-\mathrm{K}$

1902b Bythinella cyclothyra var. gracilis Klika. - Andreae, p. 25 (non Bythinella cyclothyra var. gracilis Klika, 1891).

1903 [Bythinella cyclothyra Böttg.] var. gracilis Klika. Andreae, p. 541 (non Klika, 1891).

1904a Bythinella cyclothyra (Böttg.) var. gracilis Klika. Andreae, p. 17 (non Klika, 1891).

1904b Bythinella cyclothyra (Böttg.) var. gracilis Klika. Andreae, p. 253 (non Klika, 1891).

1926 Bythinella (Bythinella) cf. cyclothyra gracilis Klika. - Wenz, p. 2022.

Holotype. - NHMW 2017/0092/0009: diameter: $1.1 \mathrm{~mm}$, height: $2.0 \mathrm{~mm}$ (Fig. 3H).

Paratypes. - NHMW 2017/0092/0010: diameter: $1.05 \mathrm{~mm}$, height: $2.1 \mathrm{~mm}$ (Fig. 3I); NHMW 2017/0092/0011: diameter: $1.1 \mathrm{~mm}$, height: $1.85 \mathrm{~mm}$ (Fig. 3J); NHMW 2017/0092/0012: diameter: $1.0 \mathrm{~mm}$, height: $1.95 \mathrm{~mm}$ (Fig. 3K).

Type horizon and locality - Grey clayey marl ("Landschneckenmergel"), middle Miocene, late Langhian/early Serravallian (MN 6). Nowa Wieś Królewska at Opole (Poland).

Material. - 58 specimens (NHMW 2017/0092/0013).
Etymology. - In honor of Dietrich Kadolsky, specialist for Cenozoic Hydrobiidae.

Diagnosis. - Small ovate-conical hydrobiid with strongly convex whorls, deep suture and broad varix-like swelling behind ovoid aperture; peristome continuous, umbilicus chink-like.

Description. - Small, ovate-conical shell comprising 3.5 strongly convex teleoconch whorls and about 1.3 smooth, convex protoconch whorls of $350 \mu \mathrm{m}$ diameter with broad initial part. Maximum diameter of spire whorls at mid-height or slightly above. Suture deeply incised. Base moderately convex. Varix-like swelling on last whorl distinctly behind peristome, resulting in bulgy outline of last whorl in apical view. Suture weakly sloping downwards after swelling. Aperture ovoid, slightly prosocline in lateral view. Peristome continuous, thin, detached from base; chink-like, narrow umbilicus. Shell surface smooth aside from densely spaced, weakly prosocline growth lines.

Remarks. - This species is somewhat variable concerning its ovate-conical outline and width of the aperture; similarly, the varix is only weakly developed in some specimens. This species was originally identified by Andreae (1902b) as Bythinella cyclothyra var. gracilis Klika, which was described by Klika (1891) from the lower Oligocene limestones of Dvérce (= Wärzen) in Czech Republic. This geologically much older species is clearly distinguished from Martinietta kadolskyi by its higher last whorl, the convex base and larger size. Moreover, a placement in Bythinella Moquin-Tandon, 1856 as suggested by Andreae (1902b) and Wenz (1926) is clearly excluded by the conical apex, which is typically low, dome-shaped in Bythinella. Instead, the small size, the strongly convex whorls and the presence of a varix-like swelling close to the aperture suggest a placement in Martinietta Schlickum, 1974 as revised by Kadolsky \& Piechocki (2000) and Kadolsky (2008). Its type species Martinietta striata (K. Fischer \& Wenz, 1916), from the Aquitanian of Germany, is distinguished from the species from Opole by its even more convex whorls and the rapidly contracting base. In addition, its aperture is weakly opisthocline in lateral view and the varix is closer to the aperture. Martinietta tumida Kadolsky \& Piechocki, 2000, from the Burdigalian and early Langhian of Bełchatów in Poland, is stout and much broader than M. kadolskyi. Martinietta meizon Kadolsky, 2008, from the Chattian of the Rhön Mountains in Germany, is highly reminiscent of the Polish species. Aside from the huge stratigraphic gap, which makes a closer relation unlikely, the weaker suture, opisthocline aperture and the terminal position of the varix allows a separation from M. kadolskyi. 
Occurrence. - Only known from Nowa Wieś Królewska at Opole (Poland).

Superfamily Littorinoidea Children, 1834

Family Pomatiidae Newton, 1891 (1828)

\section{Genus Pomatias Studer in Coxe, 1789}

Type species. - Nerita elegans Müller, 1774; by monotypy. Recent, Europe.

\section{Pomatias schrammeni (Andreae, 1902)}

Figure 3L-Q

*1902a Cyclostoma schrammeni nov. sp.; Andreae, p. 2, text-fig. 5.

1902b Cyclostoma schrammeni m. - Andreae, p. 22.

1903 Cyclostoma schrammeni n. sp. - Andreae, p. 539.

1904b Cyclostoma schrammeni m. - Andreae, p. 17.

1904b Cyclostoma schrammeni m. - Andreae, p. 252.

1908 Cyclostoma Schrammeni. - Wegner, p. 112.

1923 Pomatias schrammeni (Andreae). - Wenz, p. 1811.

? 1925 Pomatias Schrammeni Andr. - Rotarides, p. 132.

? 1966 Pomatias rivulare (Eichwald). - Steklov, p. 121, pl. 1, figs 8-10 (non Cyclostoma rivularis Eichwald, 1829).

1995 Pomatias rivulare (Eichwald, 1829). - Stworzewicz, p. 28, figs 12, 13 (non Eichwald, 1829).

? 2007 Pomatias cf. rivulare (Eichwald). - M. Wagner \& Matl, p. 303 (non Eichwald, 1829).

? 2013 Pomatias rivulare (Eichwald, 1829). - Stworzewicz et al., p. 182, fig. 3a (non Eichwald, 1829).

2016 Pomatias schrammeni. - Höltke et al., p. 235.

Material. - More than 100 specimens and fragments (NHMW 2017/0092/0014); 56 opercula (NHMW 2017/0092/0015).

Dimensions. - Largest fragment of last whorl with peristome: diameter: $15 \mathrm{~mm}$ (Fig. 30).

Description. - Relatively stout shell with about 3-4 regularly convex teleoconch whorls and deeply incised suture. Protoconch high conical, somewhat mammilate, consisting of 1.7 smooth whorls with deep suture. Initial part low conical, later whorl increase rapidly in height. Transition into teleoconch indicated by abrupt onset of spiral sculpture on first teleoconch whorl consisting of 11 prominent, weakly granulose spiral cords separated by slightly broader interspaces. The granulation results from intersections with densely spaced delicate growth lines, becoming obsolete or only very weak on later whorls. Secondary spiral cords become successively intercalated from second teleoconch whorl onwards, attaining roughly same strength as primary cords, resulting in about 40, regularly spaced spiral cords of equal strength on last whorl (including base). Prosocline growth lines become more prominent during growth, forming distinct axial sculpture in interspaces between spiral cords without intersecting these on last whorl. Umbilicus moderately wide, perspective. Aperture nearly circular, peristome thin. Operculum multispiral, narrowly coiled; nucleus broad, opercular suture distinct, alate area narrow.

Remarks. - This species is characterized by its stout outline, distinguishing it from the more elongate Miocene species, such as Pomatias consobrinus (Sandberger, 1875), $P$. conicus (Klein, 1853) and P. bisulcatus (von Zieten, 1830) (see Stworzewicz 1995, Harzhauser \& Kowalke 2002, Harzhauser \& Binder 2004, Harzhauser et al. 2014b, Salvador 2014). Pomatias schrammeni is reminiscent of the extant Pomatias rivularis (Eichwald, 1829) in shape and general sculpture. They can be distinguished by the shorter protoconch and less convex last protoconch whorl of $P$. rivularis and the much more prominent, raised and granulose spiral cords on early spire whorls of $P$. schrammeni (based on comparison with specimens of $P$. rivularis in the NHMW collections). Fehér et al. (2009) documented that the European occurrences of Pomatias rivularis are based on a geologically very young radiation during the Holocene. A Miocene origination of $P$. rivularis is unlikely (Zoltán Fehér personal communication May $6^{\text {th }}$ 2017). Therefore, Miocene occurrences mentioned by Steklov (1966), Stworzewicz (1995), M. Wagner \& Matl (2007) and Stworzewicz et al. (2013) as Pomatias rivularis or as $P$. cf. rivularis might rather represent $P$. schrammeni or related species.

Occurrence. - Aside from Nowa Wieś Królewska at Opole (Poland), this species was also described from the Sarmatian of Déva and Tötös in Romania by Rotarides (1925). These occurrences, however, will need confirmation. Similarly, the status of the subspecies Potamides schrammeni

Figure 3. Aciculidae, Hydrobiidae, Pomatiidae and Lymnaeidae. • A, B - Platyla callosiuscula (Andreae, 1904) (NHMW 2017/0092/0006). - C, D - Platyla falkneri Boeters, Gittenberger \& Subai, 1989 (NHMW 2017/0092/0007). • E, F, G - Renea pretiosa (Andreae, 1904) (NHMW 2017/0092/0008). • H, I, J, K - Martinietta kadolskyi sp. nov.; H - holotype (NHMW 2017/0092/0009); I - paratype (NHMW 2017/0092/0010); J - paratype (NHMW 2017/0092/0011); K - paratype (NHMW 2017/0092/0012). • L, M-N, O, P, Q - Pomatias schrammeni (Andreae, 1902); L, M-N - shells (NHMW 2017/0092/0014); P, Q - opercula (NHMW 2017/0092/0015). • R, S - ?Lymnaea sp. (NHMW 2017/0092/0016). - T, U - Stagnicola cf. palustriformis (Gottschick, 1911) (NHMW 2017/0092/0017). 


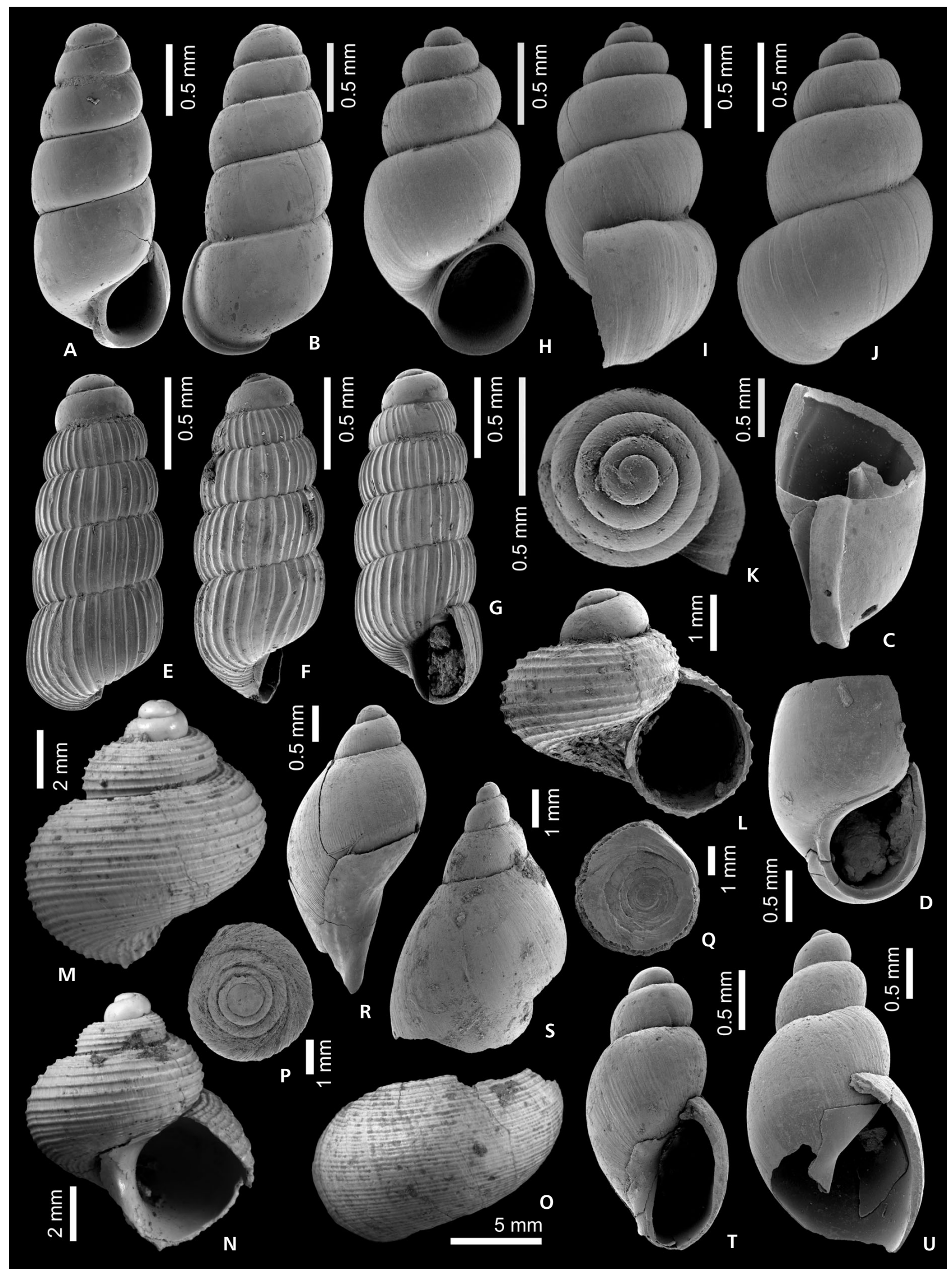


bihariensis Rotarides, 1925, from the Sarmatian of Romania, must be re-evaluated. Additional occurrences might have been reported as Pomatias rivularis from the early middle Miocene (Badenian) of Bełchatów and Szczerców in Poland (Stworzewicz 1995, M. Wagner \& Matl 2007) and the late middle Miocene (Sarmatian) of Zwierzyniec in Poland (Stworzewicz et al. 2013). Miocene occurrences in Ciscaucasia might be represented by $P$. rivularis sensu Steklov (1966).

Subclass Heterobranchia Burmeister, 1837

Order Hygrophila A. Férussac, 1822

Suborder Branchiopulmonata Morton, 1955

Superfamily Lymnaeoidea Rafinesque, 1815

Family Lymnaeidae Rafinesque, 1815

\section{? Genus Lymnaea Lamarck, 1799}

Type species. - Helix stagnalis Linnaeus, 1758; by monotypy. Recent, Europe.

\section{?Lymnaea sp.}

Figure 3R, S

Material. - 5 fragmentary specimens (NHMW 2017/0092/0016).

Dimensions. - Largest spire fragment: diameter: $4.8 \mathrm{~mm}$, height: $7.5 \mathrm{~mm}$ (Fig. 3S); estimated height $\sim 10 \mathrm{~mm}$.

Description. - The fragmentary specimens represent a small, moderately stout species with broad spire and large, inflated last (preserved) whorl. Maximum diameter of whorls below mid-whorl with weakly convex adapical part and narrow subsutural cord; growth lines densely spaced, prominent, spirally interrupted by nearly smooth bands. Aperture not preserved; inner lip forms thin sheet covering parts of base and umbilicus; columella slightly twisted.

Remarks. - This species is recognized easily in the material from Nowa Wieś Królewska at Opole by its broad spire, inflated last (preserved) whorl and the characteristic sculpture of spirally interrupted growth lines. This sculpture points to a placement of the species in Lymnaea (see Jackiewicz 1998). Overall, the fragments are reminiscent of juvenile specimens of the widespread early to middle Miocene Lymnaea dilatata (Noulet, 1854) as illustrated by Finger (1998), but a clear identification of the available fragments is difficult. Moreover, neither Finger (1998) nor Salvador \& Rasser (2014) describe this microsculpture from L. dilatata.

Occurrence. - It is unclear if this species occurs also at other localities aside from the middle Miocene of Nowa Wieś Królewska at Opole (Poland).

\section{Genus Stagnicola Jeffreys, 1830}

Type species. - Lymnaea communis Jeffreys, 1830; by monotypy. Recent, Europe.

\section{Stagnicola cf. palustriformis (Gottschick, 1911)} Figure 3T, U

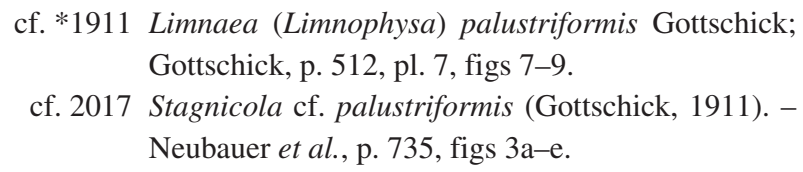
Neubauer et al., p. 735, figs 3a-e.

Material. - 5 fragmentary specimens (NHMW 2017/0092/0017).

Dimensions. - Largest spire fragment: diameter: $2.0 \mathrm{~mm}$, height: $4.0 \mathrm{~mm}$ (Fig. 3U); diameter: $1.2 \mathrm{~mm}$, height: $2.3 \mathrm{~mm}$ (Fig. 3T).

Remarks. - Only fragmentary specimens are available showing a slender shell of at least 5 convex spire whorls with prominent, prosocline growth lines. Size and overall shape correspond well to Stagnicola cf. palustriformis from the Sarmatian of Vračević described by Neubauer et al. (2017). A clear identification of the fragments, however, is impossible.

Occurrence. - Stagnicola palustriformis was described from the middle Miocene of Steinheim (Gottschick 1911). Additional occurrences, which might be conspecific, have been reported from the Badenian of Pusztamiske (Hungary), the Sarmatian of Vračević (Serbia) (Kókay 2006, Neubauer et al. 2017) and the middle Miocene of Nowa Wieś Królewska at Opole (Poland).

Superfamily Planorboidea Rafinesque, 1815

Family Physidae Fitzinger, 1833

\section{Genus Aplexa Fleming, 1820}

Type species. - Bulla hypnorum Linnaeus, 1758; by subsequent designation by Herrmannsen (1846). Recent, Europe.

\section{Aplexa cf. subhypnorum Gottschick, 1920}

Figure 4A

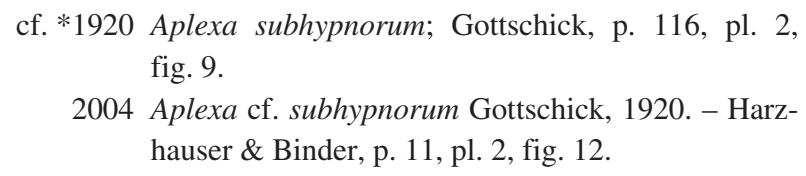
fig. 9.

2004 Aplexa cf. subhypnorum Gottschick, 1920. - Harzhauser \& Binder, p. 11, pl. 2, fig. 12. 
Material. - 1 specimen (NHMW 2017/0092/0018).

Dimensions. - Diameter: $0.95 \mathrm{~mm}$, height: $1.8 \mathrm{~mm}$.

Description. - A single specimen with partly fragmented aperture is available showing sinistrally coiled shell comprising large, obtuse protoconch and high, moderately convex teleoconch whorl. Aperture high, ear-shaped with thin outer lip and narrow, reflected inner lip.

Remarks. - The juvenile specimen cannot be clearly identified at the species level. Nevertheless, it is nearly indistinguishable from a juvenile specimen from the late Miocene of the Vienna Basin described by Harzhauser \& Binder (2004) as Aplexa cf. subhypnorum Gottschick, 1920. Fully-grown specimens of Aplexa subhypnorum from the middle Miocene of Steinheim in Germany are larger, and we did not have juveniles from that locality at hand for comparison.

Occurrence. - Aplexa subhypnorum is known from the middle Miocene of Steinheim in Germany (Gottschick 1920); all other records from the middle and late Miocene of Austria and Germany mentioned by Harzhauser \& Binder (2004) and Kókay (2006) will need confirmation based on adult specimens. The record of Physa sp. mentioned by Piechocki (1997) from the middle Miocene of Bełchatów could be another occurrence of this species.

Family Planorbidae Rafinesque, 1815

\section{Genus Anisus Studer, 1820}

Type species. - Helix spirorbis Linnaeus, 1758; by subsequent designation by Lindholm (1926). Recent, Europe.

\section{Anisus guerichi (Andreae, 1902)}

*1902b Planorbis (Gyrorbis) gürichi n. sp.; Andreae p. 21, text-fig. 10.

1903 Planorbis (Gyrorbis) Gürichi n. sp. - Andreae, p. 541.

1904a Planorbis (Gyrorbis) gürichi m. - Andreae, p. 17.

1904b Planorbis (Gyrorbis) Gürichi m. - Andreae, p. 252.

1908 Planorbis Gürichi. - Wegner, p. 112.

1923 Paraspira gürichi (Andreae). - Wenz, p. 1533.

1930 Anisus (Anisus) [gürichi (Andreae)]. - Wenz, p. 3037.

Material. - No material available.

Dimensions. - Diameter: $3 \mathrm{~mm}$, height: $0.7 \mathrm{~mm}$ (according to drawing in Andreae 1902b).
Remarks. - Andreae (1902b) described a small evolute planorbid comprising 3.5 whorls, moderately increasing in width with rounded quadrangular cross-section without keel. The whorls are flattened on the umbilical side and convex on the apical side with slightly immersed early protoconch and early teleoconch. Some specimens were reported to be somewhat open coiled. From the rather poor drawing and the cursory description no detailed conclusions can be drawn about relations with other Miocene species and even the generic placement might be questioned. Anisus angulatus (Clessin, 1877), from the early/middle Miocene of Undorf (Germany), which Wenz (1923) suggested to be identical with the Polish species, differs clearly in its higher numbers of whorls at the same size and the marked angulation (see Clessin 1885).

The species was named after the German geologist Georg Gürich. The original spelling therefore has to be corrected to "guerichi" according to Art. 32.5.2.1 of the Code.

Occurrence. - Only known from the middle Miocene of Nowa Wieś Królewska at Opole (Poland). Occurrences from the Sarmatian of Oberdorf at Weiz in Styria (Austria) mentioned by Winkler-Hermaden (1952) need confirmation.

\section{Genus Ferrissia Walker, 1903}

Type species. - Ancylus rivularis Say, 1817; by original designation. Recent, North America.

\section{Ferrissia deperdita (Desmarest, 1814)}

Figure 4B

*1814 anc. Deperditus; Desmarest, p. 19, pl. 1, fig. 14.

1923 Pseudancylus deperditus deperditus (Desmarest). Wenz, p. 1692 (cum syn.).

2017 Ferrissia deperdita (Desmarest, 1814). - Neubauer et al., p. 736, figs 3j, k, q (cum syn.).

Material. - 1 specimen (NHMW 2017/0092/0019).

Dimensions. - Diameter: $1.4 \mathrm{~mm}$, length: $1.9 \mathrm{~mm}$.

Remarks. - This species was recently discussed in detail by Harzhauser et al. (2014b), Salvador et al. (2015), Salvador \& Rasser (2016a) and Neubauer et al. (2017).

Occurrence. - Known from numerous middle Miocene localities in Austria, southern Germany, Hungary, Serbia, Switzerland and the Rhône Basin in southern France (Neubauer et al. 2017).

Clade Eupulmonata Haszprunar \& Huber, 1990

Superfamily Ellobioidea L. Pfeiffer, 1854 (1822)

Family Carychiidae Jeffreys, 1830 


\section{Genus Carychiopsis Sandberger, 1872}

Type species. - Pupa dhorni Deshayes, 1863; by subsequent designation by Cossmann (1889a); see Harzhauser et al. (2014a) for discussion on designation of type species. Paleocene, France.

\section{Carychiopsis surai (Stworzewicz, 1999)}

Figure 4E, F

1977 Carychium (Carychiopsis) schwageri Reuss. Strauch, p. 161, pl. 20, fig. 79 (non Pupa Schwageri Reuss, 1868).

*1999a Carychium surai n. sp.; Stworzewicz, p. 271, figs 25-29.

Material. - 13 specimens (NHMW 2017/0092/0020), 1 specimen (NHMW 2006z0138/0007, illustrated in Strauch 1977, pl. 20, fig. 79).

Dimensions. - Diameter: $1.25 \mathrm{~mm}$, height: $2.7 \mathrm{~mm}$ (Fig. 4E).

Remarks. - This species is reminiscent of the early Miocene Carychiopsis schwageri (Reuss, 1868) from Tuchořice, with which it was intermingled by Strauch (1977). Carychiopsis schwageri and the syntopic Carychiopsis prisyazhnyuki Stworzewicz, 1999 both differ from C. surai in the prominent spiral sculpture on the early teleoconch and the presence of two parietal lamellae (see Harzhauser et al. 2014a).

Occurrence. - Early and middle Miocene of Bełchatów in Poland (Stworzewicz 1999a) and Nowa Wieś Królewska at Opole (Poland).

\section{Genus Carychiella Strauch, 1977}

Type species. - Carychium eumicrum Bourguignat, 1857; by original designation. Miocene, Europe.

\section{Carychiella eumicrum (Bourguignat, 1857)}

Figure 4C, D

*1857 Carychium eumicrum; Bourguignat, p. 223.
1977 Carychium (Carychiella) eumicron [sic!] Bourguignat 1857 s. $1 .-$ Strauch, p. 159 , pl. 14, figs $13-15$, pl. 17, fig. 53, pl. 19, fig. 76.

1999a Carychium eumicrum Bourguignat. - Stworzewicz, p. 264, figs 5,6 .

2014a Carychiella eumicrum (Bourguignat, 1857). - Harzhauser et al., p. 837, fig. 5h-j.

2015 Carychium (Carychiella) eumicron [sic!] Bourguignat, 1857. - Salvador, p. 38, fig. 1.

2016b Carychium eumicrum Bourguignat, 1857. - Salvador et al., p. 135, fig. 2 r.

2016 Carychiella eumicrum (Bourguignat, 1857). - Jochum et al., p. 4, figs 2, 3 .

2017 Carychiella eumicrum (Bourguignat, 1857). - Neubauer et al., p. 743, figs 4m, n, q (cum syn.).

Material. - 8 specimens (NHMW 2017/0092/0021), 3 specimens (NHMW 2006z0138/0003, including specimen illustrated in Strauch 1977, pl. 17, fig. 53), 5 specimens (NHMW 2006z0138/0004, including specimens illustrated in Strauch 1977, pl. 14, figs 13, 14, pl. 19, fig. 76).

Dimensions. - Diameter: $0.47 \mathrm{~mm}$, height: $0.95 \mathrm{~mm}$ (Fig. 4C).

Remarks. - This species was described and discussed in detail by Stworzewicz (1999a), Harzhauser et al. (2014b), Jochum et al. (2016) and Neubauer et al. (2017). The first revision of this species by Strauch (1977) was partly based on specimens from Opole.

Occurrence. - Hochheim am Main, Germany (late Oligocene; Bourguignat 1857); Bełchatów, Poland, layers Beł-B (early MN 5; Stworzewicz 1999a); Tuchořice, Lipno and Kralupy, Czech Republic (early Miocene, MN 3b; Harzhauser et al. 2014a); Undorf and Sandelzhausen, southern Germany (MN 5; Stworzewicz 1999a, Salvador 2015, Salvador et al. 2016a); Rein Basin, Austria (late MN 5; Harzhauser et al. 2014b); Nowa Wieś Królewska at Opole, Poland (MN 6; Strauch 1977, Stworzewicz 1999a); Várpalota, Hungary (Sarmatian; Kókay 2006).

\section{Genus Carychium Müller, 1773}

Type species. - Carychium minimum Müller, 1774; by subsequent monotypy. Recent, Europe.

Figure 4. Physidae, Planorbidae, Carychiidae and Azecidae. • A - Aplexa cf. subhypnorum Gottschick, 1920 (NHMW 2017/0092/0018). B - Ferrissia deperdita (Desmarest, 1814) (NHMW 2017/0092/0019). - C, D - Carychiella eumicrum (Bourguignat, 1857) (NHMW 2017/0092/0021). - E-F - Carychiopsis surai (Stworzewicz, 1999) (NHMW 2017/0092/0020). • G, H, I - Carychium nouleti Bourguignat, 1857 (NHMW 2017/0092/0026); I - protoconch of G. • J, K, L, M - Carychium stworzewiczae sp. nov.; J - holotype (NHMW 2017/0092/0022); K - paratype (NHMW 2017/0092/0023); L - paratype (NHMW 2017/0092/0024); M - protoconch of K. • N, O, P - Azeca sp.; N - Azeca sp. (NHMW 2017/0092/0030); O - Azeca sp. (NHMW 2017/0092/0028); P - Azeca sp. (NHMW 2017/0092/0029). R, S - Azeca frechi Andreae 1902 (NHMW 2017/0092/0027). 


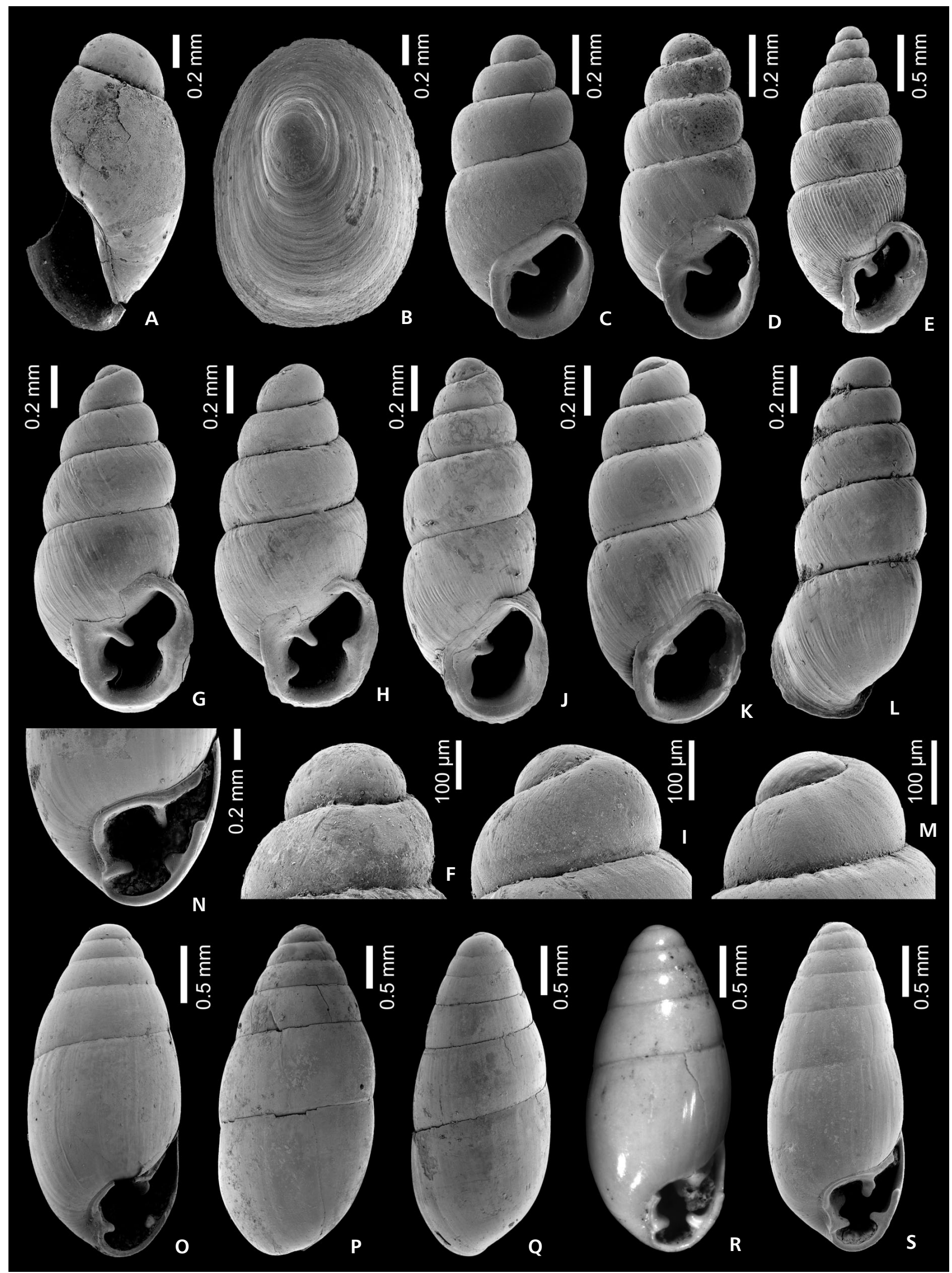


Carychium stworzewiczae sp. nov. Figure $4 \mathrm{~J}-\mathrm{M}$

*1857 Carychium eumicrum; Bourguignat, p. 223.

1902b Carychium laeve Böttg. - Andreae, p. 21 (non Carychium minutissimum var. laevis O. Boettger, 1884).

1903 Carychium laeve Böttg. - Andreae, p. 541 (non O. Boettger, 1884).

1904a Carychium laeve Böttg. - Andreae, p. 17 (non O. Boettger, 1884).

1904b Carychium laeve Böttger. - Andreae, p. 251 (non O. Boettger, 1884).

1977 Carychium (Carychiella) crossei Denainvilliers 1875. - Strauch, p. 161, pl. 14, figs 19, 20, pl. 17, figs 55, 56 (non Carychium crossei Denainvilliers, 1875).

2016 Carychium crossei. - Höltke et al., p. 235 (non Denainvilliers, 1875).

Holotype. - NHMW 2017/0092/0022: diameter: $0.65 \mathrm{~mm}$, height: $1.6 \mathrm{~mm}$ (Fig. 4J).

Paratypes. - NHMW 2017/0092/0023: diameter: $0.62 \mathrm{~mm}$, height: $1.58 \mathrm{~mm}$ (Fig. 4K, M); NHMW 2017/0092/0024: diameter: $0.68 \mathrm{~mm}$, height: $1.55 \mathrm{~mm}$ (Fig. 4L).

Type horizon and locality. - Grey clayey marl ("Landschneckenmergel"), middle Miocene, late Langhian/early Serravallian (MN 6). Nowa Wieś Królewska at Opole (Poland).

Material. - 203 specimens (NHMW 2017/0092/0025), 6 specimens (NHMW 2006z0138/0002, including specimens illustrated in Strauch 1977, pl. 17, figs 55, 56), 6 specimens (NHMW 2006z0138/0001, including specimens illustrated in Strauch 1977, pl. 14, figs 19, 20).

Etymology. - In honor of Ewa Stworzewicz in respect for her contributions to Polish malacology.

Diagnosis. - Moderately large for genus; slender fusiform with slightly thickened and continuous peristome; columellar lamella nearly obsolete; prominent parietal lamella; central palatal knob slightly behind peristome.

Description. - Slender fusiform shells of four teleoconch whorls with incised suture. Protoconch consisting of slightly more than one high, moderately convex whorl of $280 \mu \mathrm{m}$ in diameter and $180 \mu \mathrm{m}$ in height; initial part low, convex; entire protoconch covered with densely spaced spirals of tiny pits. First teleoconch whorls convex, last whorl slightly pulled in, slightly higher than spire, covered by prosocline to weakly sigmoidal growth lines. Tiny pits on surface of first teleoconch whorl fade out later. Aperture ovoid with weak posterior angulation. Peristome slightly thickened and continuous; outer lip and basal lip reflected. Weak to obsolete columellar lamella on nearly straight columella; prominent parietal lamella at junction from columella to parietal wall. Parietal callus thin but well demarcated from base. Central palatal knob slightly behind peristome. Umbilicus narrow, slit-like, largely covered by broad, inner lip.

Remarks. - This species from Opole was treated variously as Carychium leave O. Boettger, 1884 or C. crossei Denainvilliers, 1875 in the literature. O. Boettger (1884) reported a height of $1.25 \mathrm{~mm}$ for his Carychium leave and typical Carychiella eumicrum (with which it was mixed in the NHMW collection) range around $1 \mathrm{~mm}$ in height (see Stworzewicz 1999a, Harzhauser et al. 2014a, Neubauer et al. 2017). Carychium crossei Denainvilliers, 1875, from the early Miocene of Dadonville in France, is in the same size range, and Prisyazhnyuk \& Stworzewicz (1995) and Stworzewicz (1999a) treated it as synonym of C. eumicrum. Strauch (1977) described and illustrated specimens from Opole, which he identified as Carychium crossei, remarking that he had not seen French type material. The specimens from Opole are much larger, ranging around $1.5-1.6 \mathrm{~mm}$ in height and thus have little in common with the tiny C. crossei of Denainvilliers (1875). This discrepancy was already detected by Prisyazhnyuk \& Stworzewicz (1995), who tentatively considered the Opole specimens to represent a new species without describing it.

The Sarmatian and Pannonian Carychium sandbergeri Handmann, 1887 is reminiscent of the Polish species but differs in its much thicker and wider peristome and the very prominent lamellae and denticles.

Occurrence. - Only known from Nowa Wieś Królewska at Opole (Poland).

\section{Carychium nouleti Bourguignat, 1857}

Figure 4G-I

*1857 Carychium Nouleti; Bourguignat, p. 226.

1860 Carychium Nouleti. - Bourguignat, p. 56, pl. 11, figs 9,10 .

1902b Carychium minimum (M.) v. elongata Villa. - Andreae, p. 22 (non Carychium elongatum A. \& J.B. Villa, 1841).

1903 [Carychium minimum M.)] var. elongata Villa. Andreae, p. 541 (non A. \& J.B. Villa, 1841).

1904a Carychium minimum (M.) var. elongata Villa. - Andreae, p. 17 (non A. \& J.B. Villa, 1841).

1904b Carychium minimum (M.) var. elongata Villa. - Andreae, p. 251 (non A. \& J.B. Villa, 1841).

1977 Carychium (Saraphia) nouleti Bourguignat, 1857 
s.l. - Strauch, p. 162 , pl. 15 , figs $24,26,27$, pl. 18 , fig. 61 , pl. 20, fig. 83 (partim; non pl. 15 , fig. $25=$ C. gibbum).

2016 Carychium minimum. - Höltke et al., p. 235 (non Carychium minimum Müller, 1774).

2017 Carychium nouleti Bourguignat, 1857 s.l. - Neubauer et al., p. 740, figs 4a-e, j, o (cum syn.).

Material. - 152 specimens (NHMW 2017/0092/0026), 5 specimens (NHMW 2006z0138/0005, including specimen illustrated in Strauch, 1977, pl. 15, fig. 27), 4 specimens (NHMW 2006z0138/0006, including specimens illustrated in Strauch, 1977, pl. 18, fig. 61).

Dimensions. - Diameter: $0.75 \mathrm{~mm}$, height: $1.6 \mathrm{~mm}$ (Fig. 4G); diameter: 0.65, height: $1.45 \mathrm{~mm}$ (Fig. 4H).

Remarks. - This species was discussed in detail by Neubauer et al. (2017).

Occurrence. - Neubauer et al. (2017) listed occurrences from Sansan in France (late Langhian, MN 6), from Sarmatian deposits of Hollabrunn and Hautzendorf in Austria (Schütt 1967, Reischütz 2000), Nowa Wieś Królewska at Opole (Andreae 1902b, Strauch 1977), the Bakony Mts. in Hungary (Kókay 2006) and Zwierzyniec in Poland (Stworzewicz et al. 2013). A Turkish record was reported from the middle Miocene of Çifteçesme near Ayvalı by Schütt (1994).

Order Stylommatophora Schmidt, 1855

Non-achatinoid clade

Clade Elasmognatha Mörch, 1864

Superfamily Succineoidea Beck, 1837

Family Succineidae Beck, 1837

\section{Genus Oxyloma Westerlund, 1885}

Type species. - Succinea dunkeri L. Pfeiffer, 1865; by subsequent designation by Westerlund (1902). Recent, Hungary.

\section{Oxyloma minima (Klein, 1853)}

Figure 5A

*1853 Succinea minima mihi.; Klein, p. 205.

1902b Succinea cf. peregrina Sandb. - Andreae, p. 20.

1903 Succinea cf. peregrina Sandb. - Andreae, p. 541.

1904a Succinea cf. peregrina (Sandbg.). - Andreae, p. 17.

1904b Succinea peregrina (Sandbg.). - Andreae, p. 251.

1923 Succinea (Amphibina) minima minima Klein. Wenz, p. 893.

2014b Oxyloma minima (Klein, 1853). - Harzhauser et al., p. 27, pl. 9, figs 1, 2, 6 (cum syn.).
2016 Oxyloma minima. - Höltke et al., p. 235.

Material. - 8 specimens (NHMW 2017/0092/0058).

Dimensions. - Diameter: $1.35 \mathrm{~mm}$, height: $2.2 \mathrm{~mm}$ (Fig. 5A).

Remarks. - Few specimens of a tiny succineid are available. Andreae (1902b) compared this species with Succinea peregrina Sandberger, 1875 [= Oxyloma affinis (Reuss in Reuss \& Meyer, 1849); see Harzhauser et al. 2014a], from the early Miocene of Tuchořice, which is much larger. At same growth stage and scale, its spire whorls are broader and more convex, excluding that the Polish specimens are just juveniles of $O$. affinis. In contrast, the specimens correspond well to Oxyloma minima as described and illustrated by Klein (1853), Finger (1998) and Harzhauser et al. (2014b). This confirms the opinion of Wenz (1923), who already placed the record of $S$. cf. peregrina from Nowa Wieś Królewska in S. minima.

Occurrence. - Oxyloma minima is recorded from the early/middle Miocene of Undorf (S Germany), the middle Miocene of Rein (Austria) and the middle Miocene of $\mathrm{S}$ Germany (Mörsingen, Hohenmemmingen, Zwiefaltendorf, Steinheim) and Nowa Wieś Królewska at Opole (Poland).

Clade Orthurethra Pilsbry, 1900

Note. - The current system of Nordsieck (2017) does not use superfamilies to group most of the orthurethran families, they are listed alphabetically herein.

Family Acanthinulidae Steenberg, 1917

\section{Genus Acanthinula Beck, 1847}

Type species. - Helix aculeata Müller, 1774; by subsequent designation by Martens in Albers (1860). Recent, Europe.

\section{Acanthinula trochulus (Sandberger, 1872)}

Figure 5B

*1872 [Pupa] trochulus [Sandb.]; Sandberger, captions to pl. 29, figs 25-25b.

1875 Pupa (Modicella) trochulus Sandberger. - Sandberger, p. 601.

1902b Modicella aff. trochulus (Sandb.). - Andreae, p. 15.

1903 Modicella aff. trochulus Sandb. - Andreae, p. 541.

1904a Modicella aff. trochulus (Sandb.). - Andreae, p. 17.

1904b Modicella aff. trochulus (Sandb.). - Andreae, p. 251.

1999b Acanthinula trochulus (Sandberger, 1874). - Stworzewicz, p. 149, figs 27-29. 
2017 Acanthinula trochulus (Sandberger, 1872). - Neubauer et al., p. 747, figs 7a-d (cum syn.).

Material. - 7 specimens (NHMW 2017/0092/0045).

Dimensions. - Diameter: $1.9 \mathrm{~mm}$, height: $2.8 \mathrm{~mm}$ (Fig. 5B).

Remarks. - This species was described in detail by Neubauer et al. (2017), who also clarified nomenclatorial issues concerning the correct publication date.

Occurrence. - Several early and middle Miocene localities in S Germany (Mörsingen, Hohenmemmingen, Zwiefaltendorf, Undorf), early and middle Miocene of Bełchatów (Poland), middle Miocene of Nowa Wieś Królewska at Opole (Poland) and middle Miocene of Vračević (Serbia) (Neubauer et al. 2017).

\section{Acanthinula tuchoricensis (Klika, 1891)}

Figure 5C

*1891 Helix (Acanthinula) tuchořicensis n.; Klika, p. 42, text-figs 35a-c.

1902b Acanthinula tuchoricensis Klika. - Andreae, p. 10.

1903 [Acanthinula] tuchoricensis Klika. - Andreae, p. 541.

1904a Acanthinula tuchoricensis Klika. - Andreae, p. 17. 1904b Acanthinula tuchoricensis Klika. - Andreae, p. 251.

2014a Acanthinula tuchoricensis (Klika, 1891). - Harzhauser et al., p. 848, figs $7 \mathrm{r}-\mathrm{t}$ (cum syn.).

2016 Acanthinula tuchoricensis. - Höltke et al., p. 234.

Material. - 7 specimens (NHMW 2017/0092/0046).

Dimensions. - Diameter: $1.6 \mathrm{~mm}$, height: $2.1 \mathrm{~mm}$ (Fig. 5C).

Remarks. - This species was recently revised by Harzhauser et al. (2014a). Already Andreae (1902b) distinguished two acanthinulid species from Nowa Wieś Królewska at Opole: Modicella aff. trochulus (Sandb.) and Acanthinula tuchoricensis Klika. Stworzewicz (1999b), however, considered all to represent only Acanthinula trochulus, which was uncritically adopted by Harzhauser et al. (2014a).
The present data now confirm the original concept of Andreae (1902b). In the material from Nowa Wieś Królewska, Acanthinula tuchoricensis is constantly smaller than A. trochulus at the same growth stage, its spire whorls are depressed bulgy with faint mid-whorl angulation and the primary axial ribs are less distinct. Acanthinula hesslerana Jooss, 1911, from the early Miocene of Hesse in Germany, is highly reminiscent of this species but differs in its slightly larger shell height (2.6-2.7 mm versus 2.0-2.1 mm) and the lack of spiral sculpture (Jooss 1911a, 1911b; see syntype of Acanthinula hesslerana in Salvador et al. 2016a).

Occurrence. - Known from the early Miocene of Tuchořice and Lipno in Czech Republic (Harzhauser et al. 2014a) and the middle Miocene of Nowa Wieś Królewska at Opole. The record from Oberdorf at Weiz in Styria reported by Winkler-Hermaden (1952) needs confirmation.

\section{Genus Esuinella Harzhauser, Neubauer \& Georgopoulou in Harzhauser et al., 2014a}

Type species. - Helix nana Braun in Walchner, 1851; by original designation. Oligocene, Germany.

\section{Esuinella nana (Braun in Walchner, 1851)}

Figure 5D-G

*1851 Helix nana A. Braun. - Braun in Walchner, p. 1140 (p. 56 in offprint, nr. 340).

1872 [Patula] nana A. Braun sp.; Sandberger, captions to pl. 22, figs 14-14c.

1875 Patula (Acanthinula) nana A. Braun; Sandberger, p. 374.

1902b Acanthinula nana (Al. Braun). - Andreae, p. 10.

1903 Acanthinula nana Al. Br. - Andreae, p. 541.

1904a Acanthinula nana (Al. Braun). - Andreae, p. 17.

1904b Acanthinula nana (Al. Braun). - Andreae, p. 251.

1974 Planogyra nana. - Falkner, p. 240, pl. 10, fig. 4, pl. 11, figs 9, 10.

1999b Planogyra nana (A. Braun, 1851). - Stworzewicz, p. 149 , figs 32,33 .

2014a Esuinella nana (Braun in Walchner, 1851). - Harzhauser et al., p. 849, figs. 7e-g (cum syn.).

2016 Acanthinula nana. - Höltke et al., p. 234.

Figure 5. Succineidae, Acanthinulidae, Argnidae and Gastrocoptidae - A - Oxyloma minima (Klein, 1853) (NHMW 2017/0092/0058). - B - Acanthinula trochulus (Sandberger, 1872) (NHMW 2017/0092/0045). • C - Acanthinula tuchoricensis (Klika, 1891) (NHMW 2017/0092/0046). - D, E, F, G - Esuinella nana (Braun in Walchner, 1851) (NHMW 2017/0092/0047). • H, I - Spermodea plicatella (Reuss in Reuss \& Meyer, 1849) (NHMW 2017/0092/0048). • J, K, L, M - Argna oppoliensis (Andreae, 1902) (NHMW 1987/0043/0001). N, O - Gastrocopta (Sinalbinula) ferdinandi (Andreae, 1902) (NHMW 1987/0043/0003). • P, Q, R, S - Gastrocopta (Albinula) polonica sp. nov.; Q - holotype (NHMW 2017/0092/0033); P - paratype (NHMW 2017/0092/0034); R - paratype (NHMW 2017/0092/0035); S - paratype (NHMW 2017/0092/0036). 


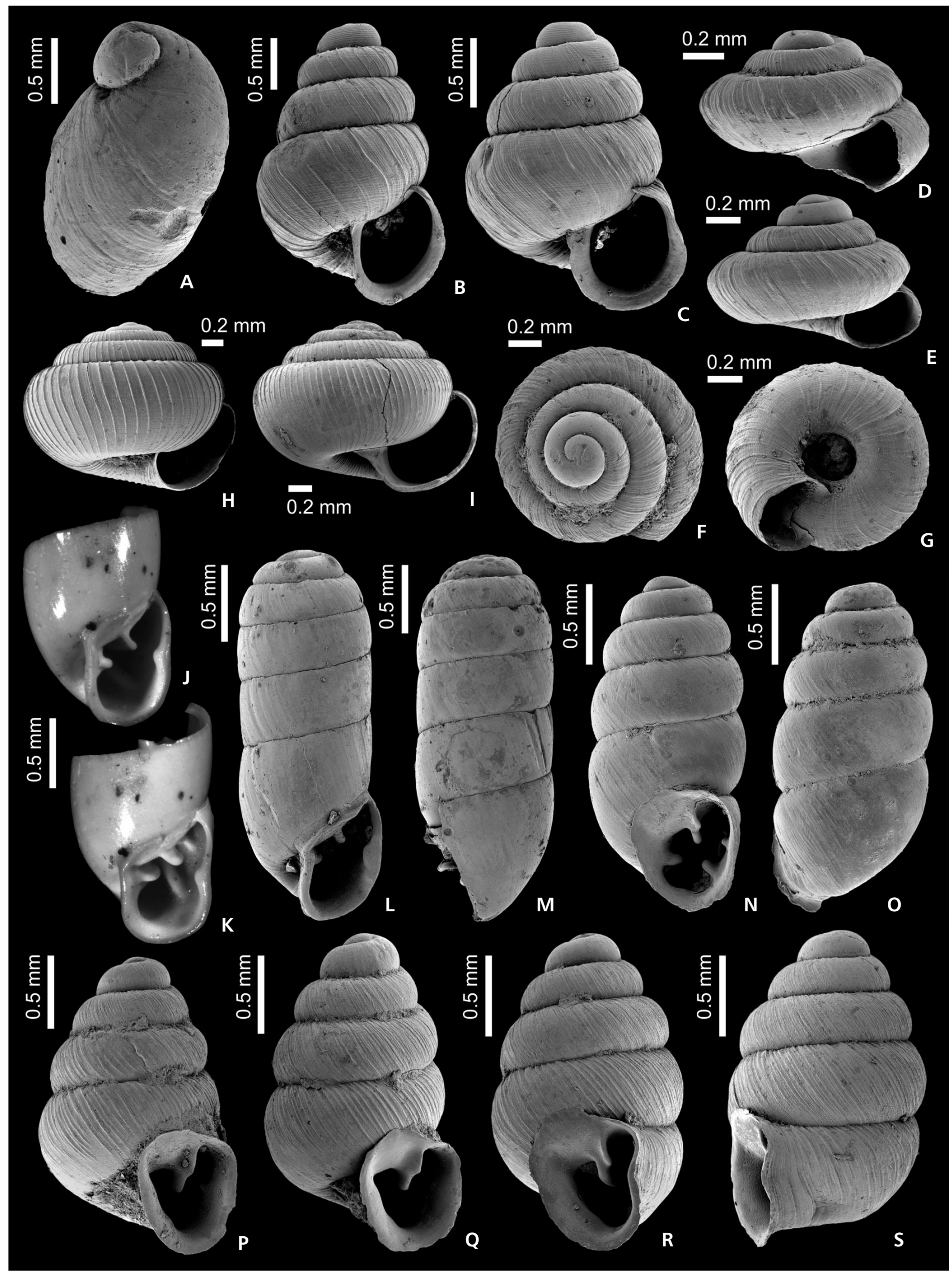


Material. - 21 specimens (NHMW 1987/0043/0006), 4 specimens (NHMW 2017/0092/0047).

Dimensions. - Diameter: $1.1 \mathrm{~mm}$, height: $0.8 \mathrm{~mm}$ (Fig. 5D); diameter: $1.25 \mathrm{~mm}$, height: $1.85 \mathrm{~mm}$ (Fig. 5E).

Remarks. - This species was discussed in detail by Stworzewicz (1999b) and Harzhauser et al. (2014a). The specimens from Opole fully match the Burdigalian specimens from Tuchořice in outline and microsculpture.

Occurrence. - Esuinella nana is known from the late Oligocene of Hochheim-Flörsheim in Germany and the early Miocene of Tuchořice in Czech Republic, Bełchatów in Poland (Stworzewicz 1999b) and Somlóvásárhely in Hungary (Kókay 2006), as well as from the middle Miocene of Nowa Wieś Królewska at Opole (Poland) and from Undorf and Zwiefaltendorf in Germany (Falkner 1974).

\section{Genus Spermodea Westerlund, 1902}

Type species. - Helix lamellata Jeffreys, 1830; by subsequent designation by Pilsbry (1926). Recent, Great Britain.

\section{Spermodea plicatella (Reuss in Reuss \& Meyer, 1849)} Figure 5H, I

*1849 H.[elix] plicatella m.; Reuss in Reuss \& Meyer, p. 21, pl. 1, fig. 10.

1974 [Spermodea] plicatella (Reuss). - Falkner, p. 233.

2014a Spermodea plicatella (Reuss in Reuss \& Meyer, 1849). - Harzhauser et al., p. 850, figs 7h-k (cum syn.).

Material. - 5 specimens (NHMW 2017/0092/0048).

Dimensions. - Diameter: $1.85 \mathrm{~mm}$, height: $1.4 \mathrm{~mm}$ (Fig. 5I); diameter: $1.85 \mathrm{~mm}$, height: $1.55 \mathrm{~mm}$ (Fig. 5H).

Remarks. - Already Falkner (1974) identified specimens from Opole as Spermodea plicatella (Reuss in Reuss \& Meyer, 1849). This species was originally described from the early Miocene of Tuchořice and was recently revised by Harzhauser et al. (2014a). The comparison of both occurrences based on SEM studies fully confirmed Falkner's view. Spermodea candida Falkner, 1974, from the early/middle Miocene of Undorf in S Germany, and Spermodea augusti Schlickum, 1978, from the late Miocene of Öcs in Hungary, differ in their much higher spire and the narrower umbilicus.

Occurrence. - Recorded from the Oligocene of Hochheim-Flörsheim and Hoppetenzell (Germany), the early Miocene of Donaurieden, Theobaldshof/Rhön (Germany) and Tuchořice (Czech Republic) (Wenz 1923, Moayedpour 1977) and the middle Miocene of Nowa Wieś Królewska at Opole (Poland).

Family Argnidae Hudec, 1965

\section{Genus Argna Cossmann, 1889}

Type species: Pupa (Coryna) proexcessiva Sacco, 1889; by monotypy. Pliocene, Italy.

Note. - This genus is usually referred to as replacement name for Coryna Westerlund, 1887, non Wolff, 1811 (Hemiptera). However, Cossmann (1889b, p. 1104) only used the genus name in a species list he cited from Sacco (1889), replacing Sacco's record of "Pupa (Coryna) proexcessiva" with "Pupa (Argna) proexcessiva". He did not provide any discussion, which is why Argna cannot be considered a substitute name for Coryna.

Argna oppoliensis (Andreae, 1902)

Figure 5J-M

*1902b Coryna oppoliensis n. sp.; Andreae, p. 16, text-fig. $8 \mathrm{a}$.

1902b Coryna oppoliensis var. turrita n. v. - Andreae, p. 16 , text-fig. $8 \mathrm{~b}$.

1903 Ennea oppoliensis n. sp. - Andreae, p. 540.

1903 [Ennea oppoliensis] var. turrita n. v. - Andreae, p. 540.

1904a Ennea oppoliensis m. - Andreae, p. 16.

1904a [Ennea oppoliensis] var. turrita m. - Andreae, p. 16.

1904b Ennea oppoliensis m. - Andreae, p. 250.

1904b [Ennea oppoliensis] var. turrita m. - Andreae, p. 250.

1923 Agardhia oppoliensis (Andreae). - Wenz, p. 1038.

1934 Agardhia sp. (?oppoliensis Andr. ?proexcessiva Sacco). - Soós, p. 196, fig. 6.

1976 Argna oppoliensis (Andreae). - Schlickum, p. 10, pl. 2, fig. 28.

1978 Argna oppoliensis (Andreae). - Schlickum, p. 252, pl. 19, fig. 10.

1999b Argna oppoliensis (Andreae, 1902). - Stworzewicz, p. 135, figs 2-5 (cum syn.).

2004 Argna oppoliensis (Andreae, 1902). - Harzhauser \& Binder, p. 15, pl. 6, figs 12, 13 (cum syn.).

2006 Argna oppoliensis (Andreae), 1902. - Kókay, p. 67, pl. 25 , fig. 8 ., pl. 41 , fig. 5 .

2016 Agardhia oppoliensis. - Höltke et al., p. 235.

Material. - 54 specimens and numerous fragments (NHMW 1987/0043/0001); 3 specimens (NHMW 2017/0092/0032). 
Dimensions. - Diameter: $1.1 \mathrm{~mm}$, height: $2.8 \mathrm{~mm}$ (Fig. 5L); diameter: $1.0 \mathrm{~mm}$, height: $2.5 \mathrm{~mm}$ (Fig. 5M).

Remarks. - This species was discussed in detail by Stworzewicz (1999b), who treated also the late Miocene Argna suemeghyi Bartha, 1956 and A. reyi Schlickum, 1978 as junior synonyms of Argna oppoliensis. Our own material confirms the variability concerning the apertural features and overall slenderness observed by Stworzewicz (1999b). Therefore, we agree in uniting the middle and late Miocene specimens in a single species.

Occurrence. - Middle Miocene of Zwiefaltendorf (Germany), Várpalota (Hungary), Nowa Wieś Królewska at Opole and Bełchatów (Poland); late Miocene of Eichkogel and Richardshof (Austria) and Öcs (Hungary) (Schlickum 1976, 1978; Lueger 1981; Stworzewicz 1999b; Harzhauser \& Binder 2004; Kókay 2006).

Family Azecidae Watson, 1920

\section{Genus Azeca Fleming, 1828}

Type species. - Turbo tridens Pulteney, 1799 [= Azeca goodalli (A. Férussac, 1821)]; by monotypy. Recent, Europe.

\section{Azeca frechi Andreae 1902}

Figure 4R, S

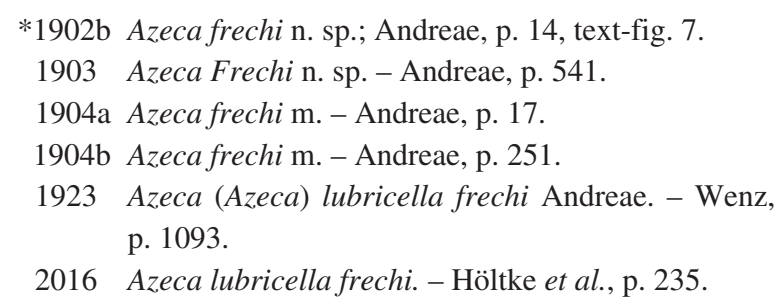

Material. - 42 specimens (NHMW 2017/0092/0027).

Dimensions. - Diameter: $1.23 \mathrm{~mm}$, height: $3.1 \mathrm{~mm}$ (Fig. 4R), largest specimen: diameter: $1.4 \mathrm{~mm}$, height: $3.35 \mathrm{~mm}$ (Fig. 4S).

Description. - Small, slender ovoid shell of 5-6 weakly convex whorls with weakly incised suture. Last whorl height about $60 \%$ of total height. Aperture low trigonal with delicately thickened, rim-like peristome. Two columellar lamellae; lower one prominent, reaching peristome, situated in lower third of columella; upper one deeper behind peristome, weak; prominent, protruding, sheet-like parietal lamella in central position; one prominent, palatal knob slightly behind peristome in lower third of aperture. Umbilicus concealed.
Remarks. - This species was treated as subspecies of Azeca lubricella O. Boettger, 1870 by Gottschick \& Wenz (1916), Wenz (1923) and Höltke et al. (2016). The more delicate peristome of $A$. frechi and its lower trigonal aperture, however, allow a separation of both species. Moreover, the constantly much smaller size of $A$. frechi supports a separation from the middle Miocene A. lubricella (see Schlickum 1976 for the neotype of that species).

Occurrence. - Described from the middle Miocene of Nowa Wieś Królewska at Opole (Poland). The occurrence in Miocene deposits at Treis a. d. Lumda in Hesse (Germany), listed by Wenz (1923), needs confirmation.

\section{Azeca sp.}

Figure $4 \mathrm{~N}-\mathrm{Q}$

1902b Azeca cf. pumila (Slav.). - Andreae, p. 15 (non Azeca pumila Slavík, 1869).

1903 Azeca cf. pumila Slav. - Andreae, p. 541 (non Slavík, 1869).

1904a Azeca cf. pumila (Slav.). - Andreae, p. 17 (non Slavík, 1869).

1904b Azeca cf. pumila Slav. - Andreae, p. 251 (non Slavík, 1869).

Material. - NHMW 2017/0092/0028: diameter: 1.35 mm, height: $3.0 \mathrm{~mm}$ (Fig. 4O); NHMW 2017/0092/0029: diameter: $1.8 \mathrm{~mm}$, height: $3.8 \mathrm{~mm}$ (Fig. 4P); NHMW 2017/0092/0030: diameter of last whorl: $1.25 \mathrm{~mm}$ (Fig. 4N); 5 fragmentary specimens (NHMW 2017/0092/0031, Fig. 4Q).

Description. - Small, stout ovoid shell comprising 5-6 weakly convex whorls with indistinct suture and conical to weakly cyrtoconoid spire. Protoconch low dome-shaped, smooth. Teleoconch whorls rapidly increasing in height, smooth aside from indistinct growth lines being most prominent below upper suture. Last whorl high, with maximum convexity at about mid-whorl; base slowly contracting resulting in ovoid outline. Aperture low trigonal with distinct posterior angulation and thickened, continuous peristome; columellar lip distinctly swollen with subhorizontal columellar lamella in lower third; columellar lamella passing continuously into peristome. Columella strongly concave above lamella and less so below. Parietal lip well demarcated from base with very prominent, protruding central parietal lamella; outer lip and basal lip thickened, forming lappet-like protrusion in lateral view reaching up to upper third of outer lip, which becomes thin adapically. Blunt central palatal knob in outer lip, slightly behind peristome, below protrusion of lip. Umbilicus completely sealed by thin sheet-like rim of the inner lip. 
Remarks. - Andreae (1902b, 1904a, b) listed this species as Azeca cf. pumila Slavík, 1869, based on similarities of aperture dentition. That species, originally described from the Burdigalian of Tuchořice and recently revised by Harzhauser et al. (2014a), is less ovoid, more slender with a higher spire and its peristome is distinctly less thickened. Moreover, the columellar lamella in in A. pumila does not reach into the peristome and the palatal knob coincides with the peristome. Azeca peneckei Andreae, 1892, from the middle Miocene (Badenian) of Styria in Austria, differs in its prominent second columellar lamella, the broader columellar callus and the lower height of the last whorl (see Harzhauser et al. 2014b). Azeca lubricella O. Boettger, 1870, from the Sarmatian of Zwiefaltendorf in Germany, is larger, more slender and bears a second columellar lamella (Gottschick \& Wenz 1916, Schlickum 1976). Azeca monocraspedon Slavík, 1869, from the Burdigalian of Tuchořice, has also only a single columellar lamella but differs in its slender outline and the smooth outer lip.

Occurrence. - Only known from Nowa Wieś Królewska at Opole (Poland).

\section{Azecidae gen. et sp. indet.}

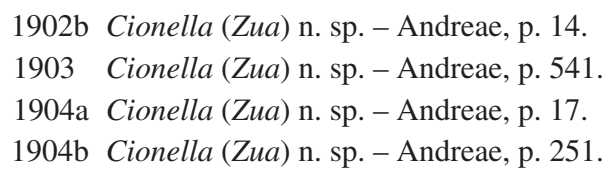

Material. - No material available.

Remarks. - Andreae (1902b) mentions several apertural fragments, which might represent a Hypnophila species. The status of this taxon is unclear.

Family Enidae Woodward, 1903 (1880)

\section{? Genus Palaeomastus Nordsieck, 2014}

Type species. - Bulimus gracilis Thomä, 1845; by original designation. Oligocene, Germany.

\section{Palaeomastus sp.}

1904a Bulimus (Napaeus) sp. indet. - Andreae, p. 17. 1904b Bulimus (Napaeus) sp. indet. - Andreae, p. 251.

Material. - No material available.

Remarks. - Andreae (1904a, b) listed a Bulimus (Napaeus) sp. without description and discussion. The central European Oligocene to middle Miocene species, traditionally placed in the genus Napaeus Albers, 1850, which is a young radiation endemic to the Canary Islands, were transferred to Palaeomastus by Nordsieck (2014). Whether the Polish taxon has to be placed in this genus remains dubious without new material.

Family Gastrocoptidae Pilsbry, 1918

\section{Genus Gastrocopta Wollaston, 1878}

\section{Subgenus Albinula Sterki, 1892}

Type species. - Pupa contracta Say, 1822; by subsequent designation by Sterki (1893). Recent, North America.

\section{Gastrocopta (Albinula) polonica sp. nov.}

Figure 5P-S

1902b Leucochilus quadriplicatum (Al. Brn.) var. lamellidens Sandbg. - Andreae, p. 17 [non Pupa (Pupilla) lamellidens Sandberger, 1858].

1903 [Leucochilus quadriplicatum Al. Br.] var. lamellidens Sandbg. - Andreae, p. 541 (non Sandberger, 1858).

1904a Leucochilus quadriplicatum (Al. Braun) var. lamellidens Sandbg. - Andreae, p. 17 (non Sandberger, 1858).

1904b Leucochilus quadriplicatum (Al. Braun). - Andreae, p. 251 [non Pupa (Vertigo) quadriplicata Sandberger, 1858].

1904b [Leucochilus quadriplicatum (Al. Braun)] var. lamellidens (Sandbg.). - Andreae, p. 251 (non Sandberger, 1858).

2016 Gastrocopta turgida. - Höltke et al., p. 235 (non Vertigo turgida Reuss in Reuss \& Meyer, 1849).

Holotype. - NHMW 2017/0092/0033: diameter: $1.3 \mathrm{~mm}$, height: $2.0 \mathrm{~mm}$ (Fig. 5Q).

Paratypes. - NHMW 2017/0092/0034: diameter: $1.3 \mathrm{~mm}$, height: $1.95 \mathrm{~mm}$ (Fig. 5P); NHMW 2017/0092/0035: diameter: $1.3 \mathrm{~mm}$, height: $1.9 \mathrm{~mm}$ (Fig. 5R); NHMW 2017/0092/0036: diameter: $1.2 \mathrm{~mm}$, height: $1.95 \mathrm{~mm}$ (Fig. 5S); NHMW 2017/0092/0036a: diameter: $1.3 \mathrm{~mm}$, height: $1.9 \mathrm{~mm}$.

Type horizon and locality. - Grey clayey marl ("Landschneckenmergel"), middle Miocene, late Langhian/early Serravallian (MN 6). Nowa Wieś Królewska at Opole (Poland).

Material. - 141 specimens and numerous fragments (NHMW 2017/0092/0037).

Etymology. - Referring to Poland. 
Diagnosis. - Medium-sized, stout conical shell with very prominent prosocline axial growth lines; triangular aperture with flaring peristome; umbilicus wide; central, prominent, weakly bifid anguloparietal lamella; columellar lamella and two weak palatal denticles deeply withdrawn in aperture.

Description. - Stout conical shell comprising 5 strongly convex whorls. Protoconch covered with weak radial wrinkles; transition into teleoconch indistinct. Teleoconch whorls entirely covered by densely spaced, malleated microsculpture. Strongly prosocline growth lines forming delicate, regularly spaced axial ribs. Last whorl low, strongly convex rapidly contracting into convex base. Distinct concavity in lower third of last whorl close behind peristome. Aperture broadly U-shaped to triangular with triangular peristome; outer lip weakly flaring, thin; basal lip, inner lip and parietal lip widening, reflected, well separated from base. Umbilicus broad and deep, slightly covered by inner lip. Columella oblique with blunt columellar lamella very deep inside aperture; parietal wall with blunt, weakly bifid anguloparietal lamella in center, with short angular part and prominent and protruding parietal part; very weak upper palatal knob and more prominent lower palatal denticle slightly above mid-whorl, distinctly behind peristome (columellar lamella and palatal denticles are hardly visible in apertural view due to their withdrawn position). Peristome and last part of last whorl protrude in lateral view.

Remarks. - According to Andreae (1902b), this species is the most abundant gastrocoptid at Opole, which is supported by the large number of shells in the NHMW collection. Andreae (1902b) identified it as Leucochilus quadriplicatum lamellidens. Wenz (1923) synonymized L. lamellidens Sandberger, 1858 with Gastrocopta turgida (Reuss in Reuss \& Meyer, 1849) along with the records from Opole by Andreae (1902b, 1904a, b), which was uncritically adopted by Höltke et al. (2016). Stworzewicz (1999b), however, considered the specimens from Nowa Wieś Królewska to represent Gastrocopta edlaueri (Wenz, 1921), which is a late Miocene species known from the Vienna Basin (Lueger 1981, Harzhauser \& Binder 2004). The prominent sculpture and the stout conical outline allow a clear separation of $G$. polonica from $G$. turgida, from the Burdigalian of Tuchořice (see Stworzewicz 1999b, Harzhauser et al. 2014a). Gastrocopta edlaueri (Wenz, 1921) is much closer to the species from Nowa Wieś Królewska concerning shape and sculpture (see Harzhauser \& Binder 2004) but differs clearly in its very prominent and strongly bent lower parietal denticle (see Wenz 1921, Lueger 1981). The new species can be moreover distinguished from G. (Albinula) steklovi Prisyazhnyuk, 1973, which bears a strong and broad columellar lamella and two distinct palatal denticles.
In his last paper on Opole, Andreae (1904b) listed also Leucochilus quadriplicatum (Al. Braun), indicating that it co-occurs with his variety Leucochilus quadriplicatum lamellidens. Based on this vague comment, Wenz (1923) listed Gastrocopta quadriplicata (Sandberger, 1858) (as subspecies of turgida) from Opole. We could not detect a second species in the collection lot and therefore include this record of Andreae (1904b) in the chresonymy.

Occurrence. - Only known from the middle Miocene of Nowa Wieś Królewska at Opole (Poland).

\section{Subgenus Sinalbinula Pilsbry, 1916}

Type species. - Pupa (Leucochila?) armigerella Reinhardt, 1877; by original designation. Recent, Japan.

\section{Gastrocopta (Sinalbinula) ferdinandi (Andreae, 1902)} Figure 5N, O

*1902b Leucochilus ferdinandi n. sp.; Andreae, p. 18, text-fig. 9.

? 1902b Leucochilus n. sp. - Andreae, p. 19.

1903 [Leucochilus] Ferdinandi n. sp. - Andreae p. 541.

? 1903 Leucochilus n. sp. - Andreae, p. 541.

1904a Leucochilus ferdinandi m. - Andreae p. 17.

? 1904a Leucochilus n. sp. - Andreae, p. 17.

1904b Leucochilus ferdinandi m. - Andreae p. 251.

? 1904b Leucochilus n. sp. - Andreae, p. 251.

1917 Gastrocopta (Sinalbinula) ferdinandi, Andreae. Pilsbry, p. 117.

1923 Gastrocopta (Sinalbinula) ferdinandi Andreae. Wenz, p. 929.

non 1976 Gastrocopta (Sinalbinula) ferdinandi (Andreae). Schütt, p. 207, fig. 11.

1981 Gastrocopta obstructa ferdinandi (Andreae). - Lueger, p. 26, pl. 2, fig. 13.

non 1999b Gastrocopta cf. ferdinandi (Andreae, 1902). Stworzewicz, p. 165, fig. 63.

2004 Gastrocopta (Sinalbinula) ferdinandi (Andreae 1902). - Harzhauser \& Binder, p. 127, pl. 8, figs $12-14$.

2006 Gastrocopta (Sinalbinula) ferdinandi (Andreae), 1902. - Kókay, p. 66, pl. 25, fig. 5.

2016 Gastrocopta obstructa ferdinandi. - Höltke et al., p. 235.

Material. - 3 specimens and two aperture fragments (NHMW 1987/0043/0003).

Dimensions. - Diameter: $0.95 \mathrm{~mm}$, height: $2.1 \mathrm{~mm}$ (Fig. 5N); diameter: 0.95 mm, height: $2.05 \mathrm{~mm}$ (Fig. 5O).

Description. - Slender subcylindrical shell with obtuse 
spire and strongly convex teleoconch whorls and incised suture. Protoconch broad, conical with delicate wrinkles. Teleoconch whorls entirely covered by delicately malleate microsculpture. Growth lines strongly prosocline. Last whorl moderately convex, nearly straight close behind aperture with weak mid-whorl concavity; base slowly contracting. Aperture elongate ovate with continuous, roughly triangular peristome. Columellar lamella very prominent, subhorizontal in middle (or slightly above) of columella; parietal wall nearly straight with prominent, long but narrow, partly bifid anguloparietal lamella; upper palatal denticle weak, knob-like; lower palatal denticle distinctly more prominent but slender, both placed well behind peristome; faint swelling represents basal denticle. Outer and basal lips slightly flaring; inner lip expanding, passing into wide but thin parietal lip, well demarcated from base. Umbilicus narrow.

Remarks. - The status of this species was obscured by the somewhat misleading illustration by Andreae (1902b), showing a more conical outline and an unrealistic high last whorl. The available specimens from Nowa Wieś Królewska are characterized by delicate apertural barriers and thin, fragile shells. Especially the basal denticle is very weak or nearly obsolete. Therefore, Leucochilus n. sp. of Andreae (1902a), which is based on a single small specimen without basal denticle, might only represent a small Gastrocopta (Sinalbinula) ferdinandi (Andreae, 1902).

Shells from the Sarmatian of Hollabrunn (Austria) and the middle Miocene of Bełchatów (Poland), described by Schütt (1967) and Stworzewicz (1999b), differ clearly in their deeply split anguloparietal lamella and the presence of additional parietal lamellae and palatal denticles.

Occurrence. - Originally described from the middle Miocene of Nowa Wieś Królewska at Opole (Poland). Additional middle Miocene records are reported from Hautzendorf (Austria) and Várpalota (Hungary), (Reischütz 2000, Kókay 2006). The stratigraphically latest occurrences are described from the late Miocene of Eichkogel, Götzendorf and Velm (Austria) (Lueger 1981, Harzhauser \& Binder 2004).

Family Lauriidae Steenberg, 1925

\section{Genus Leiostyla Lowe, 1852}

Type species. - Pupa (Leiostyla) vincta Lowe, 1852; subsequent designation by Pilsbry (1922). Recent, Madeira.

Leiostyla piserai sp. nov.

Figure 6A-G

? 1902a Vertigo (Enneopupa) aff. cylindrella (Al. Br.). - Andreae, p. 19.
? 1903 Vertigo (Enneopupa) aff. cylindrella Al. Br. - Andreae, p. 541.

? 1904a Vertigo (Enneopupa) aff. cylindrella (Al. Braun). Andreae, p. 17.

? 1904b Vertigo (Enneopupa) aff. cylindrella (Al. Braun). Andreae, p. 251.

? 1923 Enneopupa aff. cylindrella (Sandberger). - Wenz, p. 1013.

? 1967 Leiostyla (Leiostyla) gottschicki Wenz. - Schütt, p. 207 , fig. 10 .

Holotype. - NHMW 2017/0092/0038: diameter: $1.8 \mathrm{~mm}$, height: $2.5 \mathrm{~mm}$ (Fig. 6A, B).

Paratypes. - NHMW 2017/0092/0039: diameter: $1.6 \mathrm{~mm}$, height: $2.8 \mathrm{~mm}$ (Fig. 6C, D); NHMW 2017/0092/0040: diameter: $1.55 \mathrm{~mm}$, height: $2.4 \mathrm{~mm}$ (Fig. 6E); NHMW 2017/0092/0041: diameter: $1.6 \mathrm{~mm}$, height of last whorl: $1.4 \mathrm{~mm}$ (Fig. 6F, G).

Type horizon and locality. - Grey clayey marl ("Landschneckenmergel"), middle Miocene, late Langhian/early Serravallian (MN 6). Nowa Wieś Królewska at Opole (Poland).

Material. - None.

Etymology. - In honor of Andrzej Pisera (Polish Academy of Science) in respect for his contributions in Paleontology.

Diagnosis. - Stout ovoid shell with prominent growth lines and U-shaped aperture with reflected peristome and pronounced sinulus formed by prominent angular lamella and blunt adapical swelling of outer lip. Prominent columellar lamella and two weak palatal denticles deep inside aperture.

Description. - Small, stout ovoid shell comprising 5.5 whorls with obtuse apex, subcylindrical periphery and rapidly contracting base. Protoconch low conical smooth aside from faintly malleate microsculpture. Transition into teleoconch indicated by onset of slightly prosocyrt, prosocline axial ribs, which become orthocline on last whorl. Spire whorls only weakly convex, suture shallow. Last whorl slightly pulled in. Aperture U-shaped with reflected peristome; narrow parietal callus incised above angular lamella. Columella short, weakly oblique with prominent, oblique columellar lamella. Parietal lamella weak, slightly behind peristome; angular lamella prominent persisting to peristome, strongly bent towards outer lip. Outer lip with blunt palatal swelling directly at peristome, forming broad sinulus with angularis. Knob-like small upper palatal denticle and slightly more prominent lower palatal denticle are deeply withdrawn into aperture, partly hidden by palatal 
swelling of outer lip. Position of palatal denticles coinciding with moderately strong concavity of last whorl. Umbilicus moderately wide, deep.

Remarks. - Only a small number of Leiostyla species have been described so far from the European Miocene (Manganelli et al. 1990, Prysyazhniuk 2015a). Of these, Leiostyla gottschicki (Wenz, 1922), from the middle Miocene of Steinheim (Germany), is highly reminiscent of the Polish species but differs in its less pronounced sinulus, the weak parietal callus, the weaker swelling of the outer lip and its lower palatal plica reaches nearly the peristome and is thus less withdrawn into the aperture (Wenz 1922a, Manganelli et al. 1990). Moreover, the basal plica of L. gottschicki is missing in L. piserai. Leiostyla austriaca (Wenz, 1921), from the late Miocene of the Vienna Basin, has a comparable shape and sculpture but is distinguished by the presence of three columellar lamellae and the nearly closed, circular sinulus (see also Lueger 1981). Leiostyla krstichae Prysyazhniuk, 2015, from the Sarmatian of Vračević in Serbia, differs in its strongly oblique columellar lamella, the prominent palatal plica, the more spherical outline the prominent axial ribs and the unusual sutural cord. Leiostyla ex gr. gottschicki sensu Prysyazhniuk (2015a), from the middle Miocene of the Letichev district in Ukraine, has a more prominent parietal lamella and a weak supracolumellar lamella. Vertigo (Enneopupa) aff. cylindrella sensu Andreae (1902b), based on a single shell fragment with damaged peristome with prominent sinulus, seems to represent rather Leiostyla piserai.

Occurrence. - Known from the middle Miocene of Nowa Wieś Królewska at Opole (Poland). The specimen from the Sarmatian (middle Miocene) of Hollabrunn in Austria reported by Schütt (1967) might also represent this species.

Family Orculidae Pilsbry, 1918

\section{Genus Nordsieckula Harl \& Harzhauser in Harzhauser et al., 2014a}

Type species. - Pupa subconica Sandberger, 1858; late Oligocene, Germany.

\section{Nordsieckula falkneri (Hausdorf, 1995)}

Figure 6H, I

1902a Orcula n. sp. - Andreae, p. 15.

1902b Orcula n. sp. - Andreae, p. 17.

1903 Orcula n. sp. - Andreae, p. 541.

1904b Orcula n. sp. - Andreae, p. 251.

*1995 Orcula falkneri n. sp.; Hausdorf, p. 73, pl. 12, figs $1-5$. 2014a Nordsieckula falkneri (Hausdorf, 1995). - Harzhauser et al., p. 859.

Material. - 5 fragmentary specimens (NHMW 1987/0043/0007).

Dimensions. - Diameter of spire: $2.6 \mathrm{~mm}$ (Fig. 6I); last whorl: diameter: $2.6 \mathrm{~mm}$, height: $1.7 \mathrm{~mm}$ (Fig. 6H).

Remarks. - This species was described by Hausdorf (1995) based on specimens stored in the Bavarian State Collection for Palaeontology and Geology, Munich, and the Senckenberg Research Institute and Natural History Museum in Frankfurt/Main, as well as few fragments from the NHMW collection. The specimens discussed by Andreae (1902a) are lost (Hausdorf, 1995) and no further material than that studied by Hausdorf (1995) could be detected in the NHMW collection. Recently, Harzhauser et al. (2014a) have placed this species in the newly established orculid genus Nordsieckula Harl \& Harzhauser in Harzhauser et al., 2014a.

Occurrence. - Only known from the middle Miocene of Nowa Wieś Królewska at Opole (Poland) and Gründlkofen (S Germany) (Hausdorf, 1995).

Family Pleurodiscidae Wenz, 1923

\section{Genus Pleurodiscoides Nordsieck, 2014}

Subgenus Pleurodiscoides Nordsieck, 2014

Type species. - Helix (Patula) falcifera O. Boettger, 1870; by original designation. Early Miocene, Czech Republic.

\section{Pleurodiscoides (Pleurodiscoides) mamillatus (Andreae, 1904) \\ Figure 6S-U}

*1904a Pyramidula mamillata Andreae; Andreae, p. 7, 17, text-fig. 5.

1904b Pyramidula (Gonyodiscus) mamillata Andreae. Andreae, p. 251.

1919 [Pleurodiscus] mamillata(Andreae).-Wenz, p. 79.

1923 Pleurodiscus mamillatus (Andreae). - Wenz, p. 1070.

2014 P.[leurodiscoides] mamillatus (Andreae). - Nordsieck, p. 175.

2016 Pleurodiscus mamillatus. - Höltke et al., p. 235.

Material. - 1 specimen (NHMW 2017/0092/0042).

Dimensions. - Diameter: $6.6 \mathrm{~mm}$, height: $3.5 \mathrm{~mm}$ (fragmentary specimen). 
Description. - Medium-sized, low conical shell comprising about 4 whorls (last whorl missing in available specimen). First teleoconch whorl and protoconch distinctly protruding, resulting in somewhat mammilate outline in lateral view. Protoconch short, consisting of less than 0.5 whorls, convex with malleate initial part passing into spirally wrinkled microsculpture; $700 \mu \mathrm{m}$ diameter. Tops of teleoconch whorls strongly convex with deep suture, whorls rapidly increasing in width. Early teleoconch with wide-spaced, very prominent, regular, orthocline to slightly sigmoidal axial ribs (22 on first teleoconch whorl). Axial ribs become densely spaced, more irregular rarely bifurcating and slightly prosocyrt in apical view on later whorls. Periphery coinciding with rounded angulation in upper third of whorl; last whorls strongly convex above periphery and weakly convex below; axial ribs prosocline in lateral view. Base moderately convex; umbilicus perspective. Aperture unknown.

Remarks. - This species was included by Nordsieck (2014) in his new genus Pleurodiscoides, which differs from Pleurodiscus Wenz, 1919 in its more rapidly increasing teleoconch whorls, the more perspective umbilicus and distinct protoconch sculpture (Nordsieck 2014). The type species of Pleurodiscoides is P. falciferus (O. Boettger, 1870), from the Burdigalian of Tuchořice. As already discussed by Andreae (1904a), the Bohemian species differs very clearly from $P$. mamillatus in its larger size, high number of whorls, the lower spire, shallower suture and the denser sculpture (see P. falciferus in Harzhauser et al. 2014a and Nordsieck 2014).

Occurrence. - Only known from Nowa Wieś Królewska at Opole (Poland).

Family Strobilopsidae Wenz, 1915

\section{Genus Strobilops Pilsbry, 1893}

Type species. - Helix labyrinthica Say, 1817; by typification of replaced name. Recent, North America.

\section{Strobilops costatus (Clessin, 1877)}

Figure 6J-M

*1877 Strobilus costatus Sdbgr. in litt.; Clessin, p. 37.
1885 Strob. costatus Sdbgr. in Clessin. - Clessin, p. 79, pl. 7, fig. 10.

1885 Str. bilamellatus n. sp. Clessin; p. 79, pl. pl. 7, fig. 9.

1902b Strobilus costatus Sandberger. - Andreae, p. 11, fig. 6.

1903 [Strobilus] costatus Sandb. - Andreae, 541.

1904a Strobilus costatus Sandbg. - Andreae, p. 16.

1904b Strobilus costatus Sandbg. - Andreae, p. 250.

1915 Strobilops (Str.) costata (Sdbg. emend. Clessin). Wenz, p. 79, pl. 4, figs 15, 16.

1923 Strobilops (Strobilops) costata (Clessin). - Wenz, p. 1041 (cum syn.).

2016 Strobilops costata costata. - Höltke et al., p. 235.

2017 Strobilops costatus (Clessin, 1877). - Neubauer et al., p. 744, figs 6a-o (cum syn.).

Material. - 101 specimens (NHMW 1987/0043/0004), 5 specimens (NHMW 2017/0092/0043).

Dimensions. - Diameter: $2.05 \mathrm{~mm}$, height: $1.35 \mathrm{~mm}$ (Fig. 6J); diameter: $2.1 \mathrm{~mm}$, height: $1.4 \mathrm{~mm}$ (Fig. 6K).

Remarks. - This species has been described and discussed in detail by Neubauer et al. (2017), who also commented on nomenclatorial problems. The specimens from Opole agree in all conchological details with Strobilops costatus as described there from the Sarmatian of Vračević in Serbia including the microsculpture of faint spiral threads on the late protoconch and early teleoconch.

Occurrence. - Early Miocene of Undorf and Riedensheim (Germany), Handreute and Flühlen (western Austria, middle Miocene of Nowa Wieś Królewska at Opole (Poland), St. Veit an der Triesting, Hollabrunn and Hautzendorf (Austria), Sarmatian of Vračević in Serbia and middle and late Miocene of Bełchatów (Poland) (see Neubauer et al. 2017 for details).

\section{Genus Eostrobilops Pilsbry, 1927}

Type species. - Strobilops hirasei Pilsbry, 1908; by original designation. Recent, Korea.

Note. - Eostrobilops is often treated as subgenus of Strobilops (e.g. Harzhauser et al. 2014a), but should have genus rank according to Páll-Gergely et al. (2015).

Figure 6. Lauriidae, Orculidae, Pleurodiscidae and Strobilopsidae. • A-B, C-D, E, F-G - Leiostyla piserai sp. nov.; A-B - holotype (NHMW 2017/0092/0038); C-D - paratype (NHMW 2017/0092/0039); E - paratype (NHMW 2017/0092/0040); F-G - paratype (NHMW 2017/0092/0041). $\bullet$ H, I - Nordsieckula falkneri (Hausdorf, 1995) (NHMW 1987/0043/0007). • J, K, L, M - Strobilops costatus (Clessin, 1877) (NHMW 2017/0092/0043). - N, O, P, Q, R - Eostrobilops boettgeri (Andreae, 1902) (NHMW 2017/0092/0044); R - protoconch of P.・S-U - Pleurodiscoides (Pleurodiscoides) mamillatus (Andreae, 1904) (NHMW 2017/0092/0042). 


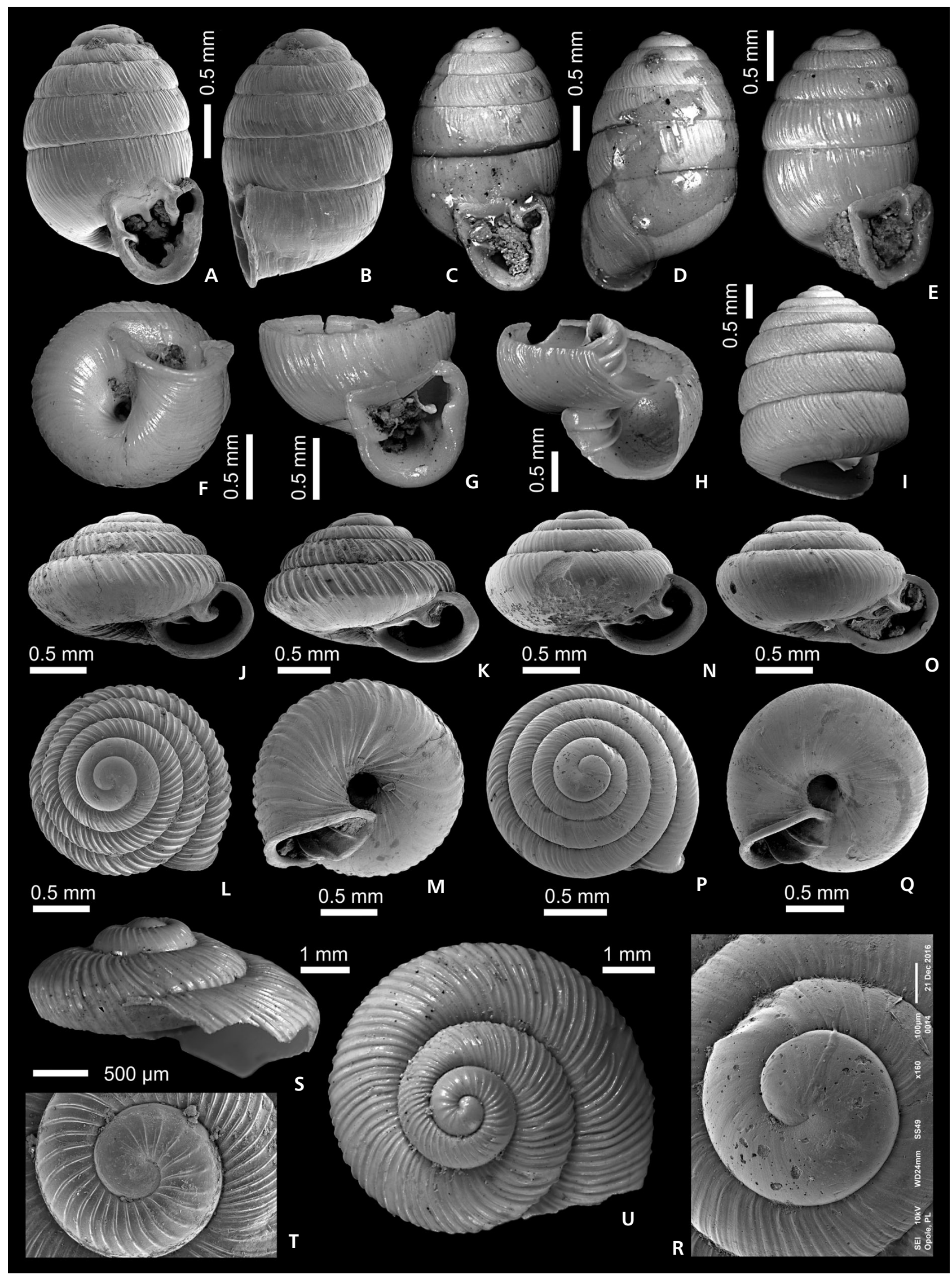




\section{Eostrobilops boettgeri (Andreae, 1902)}

Figure 6N-R

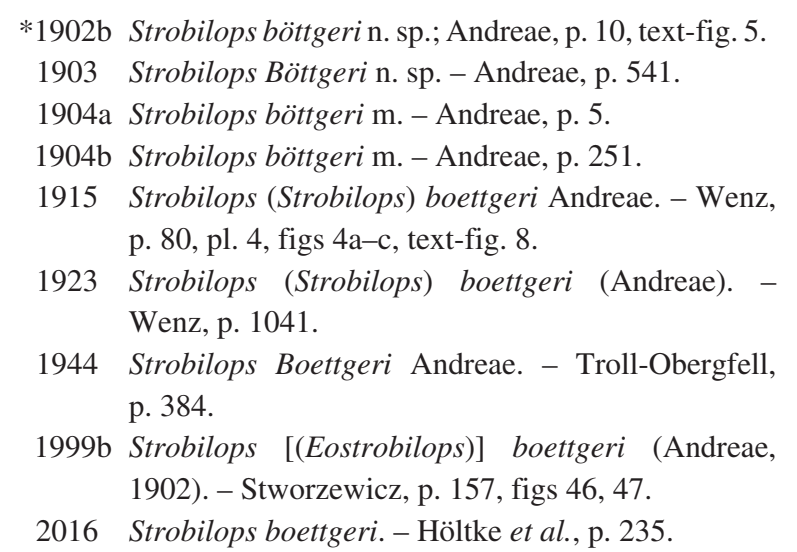

Material. - 162 specimens (NHMW 1987/0043/0005), 9 specimens (NHMW 2017/0092/0044).

Dimensions. - Diameter: $1.85 \mathrm{~mm}$, height: $1.2 \mathrm{~mm}$ (Fig. 6N); diameter: 1.72 mm, height: $1.1 \mathrm{~mm}$ (Fig. 6O).

Description. - Low conical shell comprising 3.25 moderately convex teleoconch whorls with distinct suture. Protoconch low conical, smooth, diameter ranging around $510 \mu \mathrm{m}$; transition into teleoconch indistinct, indicated by onset of low, densely spaced, weakly prosocline, poorly defined axial ribs, being most prominent close to upper suture; ribs become very weak along convex periphery of last whorl and re-appear as shallow-sigmoidal growth lines in umbilical area. Periphery of last whorl slightly above mid-whorl with regularly convex adapical part and less convex lower part. Base moderately convex; umbilicus narrow and deep. Aperture faintly angulated with broad, reflected outer and basal lip; columellar lip narrow, not reflected. Peristome interrupted along parietal wall. Upper margin of aperture attached close to periphery. Two prominent parietal lamellae; upper one very prominent, swollen, slightly reflected in adapical direction; infraparietal lamella weaker and thinner; both extend as prominent lamellae up to callus margin (for description of internal lamellae see Stworzewicz 1999b).

Occurrence. - Middle Miocene of Nowa Wieś Królewska at Opole (Poland); a Badenian occurrence was reported by Troll-Obergfell (1944) from St. Veit an der Triesting in the
Vienna Basin (Austria). Stworzewicz (1999b) reported Strobilops boettgeri from the early, middle and late Miocene of Bełchatów (Poland).

Family Truncatellinidae Steenberg, 1925

\section{Genus Truncatellina Lowe, 1852}

Type species. - Pupa linearis Lowe, 1852; by monotypy. Pleistocene, Madeira.

\section{Truncatellina lentilii (Miller, 1900)}

Figure 7A, B

*1900 Pupa (Isthmia) Lentilii; Miller, p. 406.

1912 Isthmia lentilii Miller. - Jooss, p. 37, pl. 2, figs 6-6b.

1919 Isthmia lentilii (Miller). - Gottschick \& Wenz, p. 10, pl. 1, figs 14, 15 .

1923 Truncatellina lentilii (K. Miller). - Wenz, p. 1020 (cum syn.).

1967 Truncatellina lentilii. - Schütt, p. 206, fig. 7.

1998 Isthmia lentilii (Miller 1900). - Finger, p. 18, pl. 9, fig. g.

2008 Truncatellina lentilii (Miller, 1900). - Harzhauser et al., p. 49, figs 5.5-6.

Material. - 3 specimens (NHMW 2017/0092/0057).

Dimensions. - Diameter: $0.75 \mathrm{~mm}$, height: $1.55 \mathrm{~mm}$ (Fig. 7A); diameter: $0.8 \mathrm{~mm}$, height: $1.6 \mathrm{~mm}$ (Fig. 7B).

Description. - Cylindrical shell of 5.5. whorls; protoconch low conical, consisting of 1.25 convex whorls of $480 \mu \mathrm{m}$ diameter with incised suture; surface intensively malleate. Teleoconch whorls low, bulgy, moderately convex with periphery somewhat below mid-whorl; suture incised. Early spire whorls with distinct and regular prosocline axial ribs becoming weaker and irregular on last 2-3 whorls. Last whorl nearly straight-sided close to aperture with prominent growth lines. Aperture narrow; peristome not preserved. Columellar lamella blunt, low; one prominent but narrow parietal denticle. Umbilicus open, moderately narrow.

Remarks. - This species has been listed by Andreae (1902a, b, 1904a, b). It differs from the somewhat reminiscent middle Miocene Pupilla iratiana (Dupuy, 1850) in the distinctly weaker axial sculpture (see Finger 1998,

Figure 7. Truncatellinidae and Vertiginidae. - A-B - Truncatellina lentilii (Miller, 1900) (NHMW 2017/0092/0057). C D D - Vertigo protracta (Sandberger, 1875) (NHMW 2017/0092/0049). • E, F, G, H, I - Vertigo trolli Wenz in K. Fischer \& Wenz, 1914 (NHMW 2017/0092/0050). - J, K, L, M - Vertigo antipygmaea sp. nov.; J - paratype (NHMW 2017/0092/0054); K - paratype (NHMW 2017/0092/0052); L - holotype (NHMW 2017/0092/0051); M - paratype (NHMW 2017/0092/0053). N , O - Negulopsis lineolata (Braun in Walchner, 1851) (NHMW 2017/0092/0055). •P-Q - Negulopsis raricosta (Slavík, 1869) (NHMW 2017/0092/0056). 


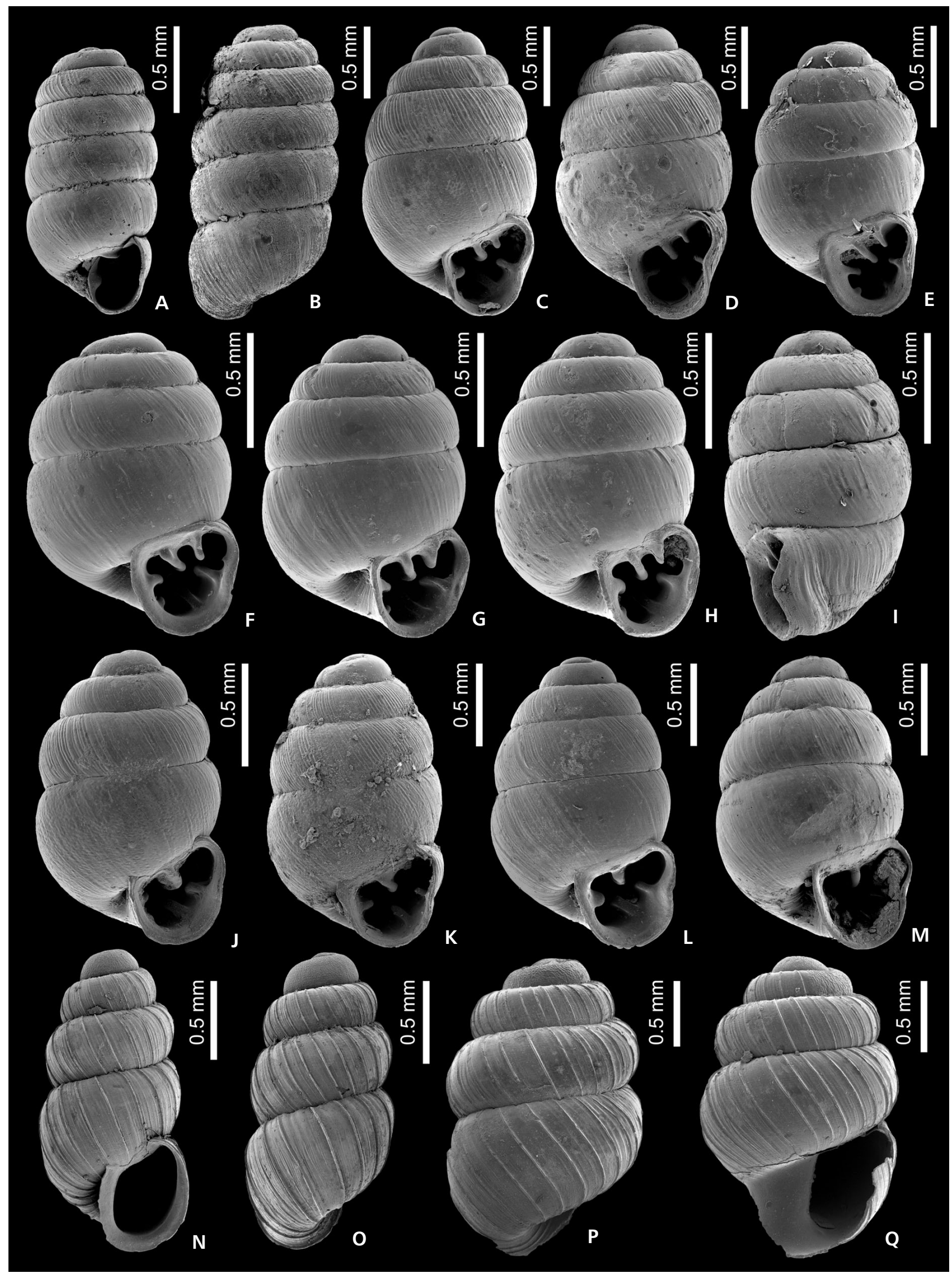


Harzhauser et al. 2008). Pupilla submuscorum Gottschick \& Wenz, 1919 is smoother and has a more pupoid outline. Truncatellina pantherae Harzhauser \& Neubauer in Harzhauser et al., 2014b is also similar in shape and sculpture but lacks a well-defined columellar lamella.

Occurrence. - A middle Miocene species, documented from Undorf and Steinheim (Germany), the Sarmatian of Hollabrunn and Gratkorn (Austria) and Nowa Wieś Królewska at Opole (Poland).

Family Vertiginidae Fitzinger, 1833

Subfamily Vertigininae Fitzinger, 1833

\section{Genus Vertigo Müller, 1773}

Type species. - Vertigo pusilla Müller, 1774; by subsequent monotypy. Recent, Europe.

\section{Vertigo protracta (Sandberger, 1875)}

Figure 7C, D

*1875 P.[upa] protracta Sandb.; Sandberger, p. 400.

1889 Vertigo (Alaea) protracta (Sbgr.). - O. Boettger, p. 300 , pl. 7, fig. 5 .

1902b [Vertigo callosa (Rss.)] mutatio alloeodus Böttger. Andreae, p. 19 (non Vertigo callosa Reuss in Reuss \& Meyer, 1849).

1903 [Vertigo] callosa Rss. - Andreae, p. 541 (non Reuss in Reuss \& Meyer, 1849).

1904a Vertigo callosa (Reuss). - Andreae, p. 17 (non Reuss in Reuss \& Meyer, 1849).

1904b Vertigo callosa Reuss. - Andreae, p. 251 (non Reuss in Reuss \& Meyer, 1849).

1914 Vertigo (Alea) protracta (Sdbg.). - Wenz in K. Fischer \& Wenz, p. 100, pl. 6, fig. 24.

1921 Vertigo (Vertigo) protracta (Sdbg.). - Wenz, p. 147, pl. 18, figs 23-33.

1921 Vertigo (Alaea) protracta suevica n. var. - Gottschick \& Wenz, p. 21, pl. 1, figs 40, 41.

1923 Vertigo (Vertigo) protracta protracta (Sandberger). - Wenz, p. 1000 (cum syn.)

1923 Vertigo (Vertigo) protracta suevica Gottschick et Wenz. - Wenz, p. 1001.

1981 Vertigo (Vertigo) protracta suevica Gottschick u. Wenz. - Lueger, p. 21, pl. 2, figs 14, 15.

1998 Vertigo protracta suevica Gottschick \& Wenz 1919. - Finger, p. 18, pl. 9, fig. i.

1999b Vertigo protracta (Sandberger, 1874). - Stworzewicz, p. 140, fig. 9.

2016 Vertigo callosa. - Höltke et al., p. 235 (non Reuss in Reuss \& Meyer, 1849).

Material. - 2 specimens (NHMW 2017/0092/0049).
Dimensions. - Diameter: $1.15 \mathrm{~mm}$, height: $1.85 \mathrm{~mm}$ (Fig. 7C); diameter: $1.15 \mathrm{~mm}$, height: $1.75 \mathrm{~mm}$ (Fig. 7D).

Description. - Medium-sized to small pupoid shell comprising 4.5 whorls; spire whorls strongly convex, rapidly increasing in height. Teleoconch whorls with prominent, prosocline growth lines, becoming weaker on last whorl. Aperture U-shaped; peristome weakly reinforced; inner lip narrowly reflected; parietal lip narrow, thin; outer lip and basal lip thin, only weakly thickened. Columella nearly straight with prominent central columellar lamella; parietal region straight, oblique with two prominent, parallel parietal lamellae of which lower one is stronger. Two long palatal plicae, lower one somewhat more prominent. Columellar lamella and parietal lamellae slightly behind peristome, palatal plicae well behind peristome. Umbilicus narrow, reduced to chink.

Remarks. - Stworzewicz (1999b) compared typical specimens of Vertigo protracta from the Oligocene of Hochheim with those from the middle Miocene of Steinheim, which were separated by Gottschick \& Wenz (1921) as subspecies suevica, and concluded that the separation is not justified. This view is adopted herein uncritically as we did not study topotypical specimens from Hochheim. Andreae (1902b) might have had specimens of this species at hand when he cursorily referred to Vertigo callosa Reuss in Reuss \& Meyer, 1849, which differs in its broader outline, the broader aperture and the much stronger apertural barriers (see Harzhauser et al. 2014a).

Occurrence. - Originally described from the late Oligocene of Hochheim (Germany); additional occurrences are reported from the middle Miocene of Steinheim (Germany), Bełchatów (Poland), Bogdanowski Karier (Ukraine), Goyani (Moldovia) and the late Miocene of Eichkogel (Austria) (Lueger 1981, Stworzewicz 1999b, Prysyazhniuk 2015b). This is the first record of this species from the middle Miocene of Nowa Wieś Królewska at Opole (Poland).

\section{Vertigo trolli Wenz in K. Fischer \& Wenz, 1914} Figure 7E-I

1902b Vertigo kochi Böttger. - Andreae, p. 19 (non Vertigo (Alea) kochi O. Boettger, 1889).

1903 [Vertigo] Kochi Böttg. - Andreae, p. 541 (non O. Boettger, 1889).

1904a Vertigo kochi (Böttg.). - Andreae, p. 17 (non O. Boettger, 1889).

1904b Vertigo kochi Böttger. - Andreae, p. 251 (non O. Boettger, 1889).

*1914 Vertigo (Alaea) trolli n. sp.; Wenz in K. Fischer \& Wenz, p. 102, pl. 7, fig. 27. 
1923 Vertigo (Vertigo) ovatula trolli Wenz. - Wenz, p. 1000 (cum syn.).

1981 Vertigo (Vertigo) ovatula trolli Wenz. - Lueger, p. 21, pl. 2, figs 6, 7 .

2006 Vertigo ovatula trolli Wenz, 1914. - Kókay, p. 64 (pars), pl. 24, fig. 2 (non fig. 1).

2016 Vertigo kochi. - Höltke et al., p. 235 (non O. Boettger, 1889).

Material. - 125 specimens (NHMW 2017/0092/0050).

Dimensions. - Diameter: $0.85 \mathrm{~mm}$, height: $1.3 \mathrm{~mm}$ (Fig. 7F); diameter: $0.85 \mathrm{~mm}$, height: $1.3 \mathrm{~mm}$ (Fig. 7H); diameter: $0.85 \mathrm{~mm}$, height: $1.25 \mathrm{~mm}$ (Fig. $7 \mathrm{G}$ ); diameter: $0.9 \mathrm{~mm}$, height: $1.35 \mathrm{~mm}$ (Fig. 7E).

Description. - Small, stout pupoid shell of 4 whorls with broad, obtuse spire and low, strongly convex spire whorls; suture incised. Sculpture consisting of densely spaced prosocline growth lines. Aperture wide, broadly triangular; peristome flaring with moderately narrow outer lip, broader reflected inner lip and broad parietal lip well demarcated from base. Columellar lamella subhorizontal to weakly oblique, narrow but prominent; two prominent parietal lamellae, reaching far into aperture, upper one slightly weaker forming an acute angle with lower one. Outer lip and last quarter of last whorl weakly incised coinciding with narrow upper palatal plica; lower palatal plica longer, reaching far into shell; know-like basal plica at transition from base to columella. All lamellae and plicae appear distinctly behind peristome. Umbilicus broad, deep, partly hidden by broad inner lip.

Remarks. - This species is very frequent in the material from Nowa Wieś Królewska. Andreae (1902b) identified it as Vertigo kochi O. Boettger, 1889, which was originally described from the late Oligocene of Hochheim in Germany (O. Boettger 1889). Already O. Boettger in a letter to Andreae (cited by Andreae 1902b) considered the species from Nowa Wieś Królewska to represent a "variety" of his Oligocene species, from which it differs in its more robust and glossy shell and the more prominent palatal plica. Wenz in K. Fischer \& Wenz (1914) reviewed the species from Nowa Wieś Królewska, confirmed the separation from V. kochi, and described it as Vertigo trolli. Stworzewicz (1999b) doubted that the Polish shells represent a distinct species and treated them as Vertigo ovatula (Sandberger, 1875). Vertigo ovatula, described from the late Oligocene of Hochheim-Flörsheim (Germany), is indeed very similar concerning apertural features but is more slender, has a shallower suture and weakly convex whorls (see V. ovatula in Nordsieck 2014, fig 17). This species is reminiscent of the co-occurring Vertigo protracta (Sandberger, 1875). Vertigo protracta differs in the absence of a basal plica, its larger size, weaker peristome, more conical spire and the parallel orientation of the palatal plicae.

Occurrence. - Middle Miocene of Nowa Wieś Królewska at Opole (Poland) and Várpalota (Hungary) and from the late Miocene of Leobersdorf (Austria) (K. Fischer \& Wenz 1914, Lueger 1981, Kókay 2006).

\section{Vertigo antipygmaea sp. nov.}

Figure 7J-M

Holotype. - NHMW 2017/0092/0051: diameter: 1.15 mm, height: $1.85 \mathrm{~mm}$ (Fig. 7L).

Paratypes. - NHMW 2017/0092/0052: diameter: $1.05 \mathrm{~mm}$, height: $1.8 \mathrm{~mm}$ (Fig. 7K); NHMW 2017/0092/0053: diameter: $1.1 \mathrm{~mm}$, height: $1.65 \mathrm{~mm}$ (Fig. 7M); NHMW 2017/0092/0054, diameter: $0.9 \mathrm{~mm}$, height: $1.4 \mathrm{~mm}$ (Fig. 7J).

Type horizon and locality. - Grey clayey marl ("Landschneckenmergel"), middle Miocene, late Langhian/early Serravallian (MN 6). Nowa Wieś Królewska at Opole (Poland).

Material. - None.

Etymology. - Referring to Vertigo pygmaea (Draparnaud, 1801).

Diagnosis. - Pupoid shell with obtuse conical spire and prominent prosocline growth lines; aperture with single central parietal lamella, blunt columellar lamella and two prominent palatal plicae.

Description. - Pupoid shell comprising 4.5 convex whorls of rapidly increasing height with moderately incised suture. Teleoconch whorls covered by densely spaced, regular pattern of prominent, prosocline growth lines. Axial sculpture becomes weaker on last whorl, which is covered by malleate microsculpture. Aperture broad U-shaped to trigonal; outer lip and basal lip thin; inner lip narrowly reflected; parietal callus narrow but distinct; sinulus broad. One prominent central columellar lamella on short columella; one central, long and very prominent parietal lamella; two long and prominent palatal plicae of which lower one is distinctly longer. Umbilicus narrow, open.

Remarks. - In terms of general shape and aperture, this species is reminiscent of the Pleistocene to Recent Vertigo pygmaea (Draparnaud, 1801), which is distinguished especially by its much smaller size and slightly less conical spire. A comparable aperture with only a single lamella plica, two palatal plicae and a single columellar lamella 
was described by Boettger (1889) from the Aquitanian of Germany as Vertigo ovatula mosbachensis. This taxon, however, differs from the Polish species by its ovate outline and smaller size (1.3 mm height).

Occurrence. - Only known from the middle Miocene of Nowa Wieś Królewska at Opole (Poland).

Subfamily Nesopupinae Steenberg, 1925

\section{Genus Negulopsis Nordsieck, 2014}

Type species. - Pupa suturalis Sandberger, 1858 (= Bulimus lineolatus Braun in Walchner, 1851); by original designation. Oligocene, Germany.

\section{Negulopsis lineolata (Braun in Walchner, 1851)} Figure $7 \mathrm{~N}, \mathrm{O}$

*1851 Bulimus lineolatus A. Braun; Braun in Walchner, p. 53.

1858 Pupa suturalis A. Braun. - Sandberger, p. 54, pl. 6, figs 2-2a.

1902b Negulus lineolatus (Al. Brn.). - Andreae, p. 17.

1903 [Negulus] lineolatus Al. Br. - Andreae, p. 541.

1904a Negulus lineolatus (Al. Braun). - Andreae, p. 17.

1904b Negulus lineolatus (Al. Braun). - Andreae, p. 251.

1944 Negulus suturalis Sandb. - Troll-Obergfell, p. 384.

1999b Negulus suturalis (Sandberger, 1858). - Stworzewicz, p. 146, figs 23-25.

2013 Negulus suturalis (Sandberger, 1858). - Stworzewicz et al., p. 191, fig. 41.

2014a Negulus suturalis (Sandberger, 1858). - Harzhauser et al., p. 854, fig. 8k-n (cum syn.).

2014 Negulopsis suturalis (Sandberger). - Nordsieck, p. 163, fig. 13.

2015 Negulopsis suturalis (Sandberger, 1858). - Harzhauser et al., p. 29, pl. 5, figs 5, 6 .

2016b Negulopsis lineolata (Sandberger, 1872). - Salvador et al., p. 141, fig. 3u (cum syn.).

2016 Negulus suturalis. - Höltke et al., p. 235.

Material. - 157 specimens (NHMW 1987/0043/0002), 2 specimens (NHMW 2017/0092/0055).
Dimensions. - Diameter: $0.9 \mathrm{~mm}$, height: $1.8 \mathrm{~mm}$ (Fig. 7N); diameter: $0.9 \mathrm{~mm}$; height: $1.8 \mathrm{~mm}$ (Fig. 7O).

Remarks. - This species was extensively described and discussed by Stworzewicz et al. (2013), Harzhauser et al. (2014a, b) and Salvador et al. (2016b). Salvador et al. (2016b) clarified the confusion between Bulimus lineolatus Braun in Walchner, 1851 and Bulimus suturalis Braun in Walchner, 1851 and pointed out that B. suturalis refers to an aciculid species (following a footnote in Sandberger 1875 , p. 397). The first available name for the nesopupinid is Bulimus lineolatus. Braun in Walchner (1851, p. 53) provides a very brief description of that species Therefore, the name is available and cannot be treated as nomen nudum as done by Wenz (1923) and Salvador et al. (2016b).

Occurrence. - A widespread species known from the Oligocene of Hochheim-Flörsheim (Germany), the early Miocene of Donaurieden, Erbach, Budenheim (Germany), the early/middle Miocene of Riedensheim (Germany), Tuchořice (Czech Republic), Bełchatów (Poland), Teiritzberg (Austria), Somlóvásárhely (Hungary) and the middle Miocene of St. Veit and der Triesting (Austria), Nowa Wieś Królewska at Opole and Bełchatów (Poland) (Wenz 1923; Stworzewicz 1999b; Troll-Obergfell 1944; Harzhauser et al. 2014a, b; Salvador et al. 2016b). The youngest occurrence is described by Harzhauser et al. (2015) from the Messinian of Moncucco Torinese (Italy).

Negulopsis raricosta (Slavík, 1869) comb. nov. Figure 7P, Q

*1869 Pupa (Pupilla) raricosta n. sp.; Slavík, p. 258, pl. 4, figs 9-11.

1902b Negulus raricostatus Slav. - Andreae, p. 17.

1903 Negulus raricostatus Slav. - Andreae, p. 541.

1904a Negulus raricostata (Slav.). - Andreae, p. 17.

1904b Negulus raricostata (Slavic.). - Andreae, p. 251.

2014a Negulus raricosta (Slavík, 1869). - Harzhauser, p. 856 , fig. $8 \mathrm{o}-\mathrm{q}$ (cum syn.).

2016 Negulus raricosta. - Höltke et al., p. 235.

Material. - 1 specimen (NHMW 2017/0092/0056).

Figure 8. Filholiidae and Clausiliidae. • A, B, C, D - Triptychia margaretae Andreae, 1904 (NHMW 2017/0092/00565). E-F, G-H, I - Serrulella andreaei Nordsieck, 1981; E-F - paratype (NHMW 1979/2083/0002); G-H - holotype (NHMW 1979/2083/0001); I - paratype (NHMW 1979/2083/0004). • J, K, L - Serrulella multiplicata Nordsieck, 1981; J, K - paratypes (NHMW 1979/2083/0005); L - paratype (NHMW 1979/2083/0004). - M-O, P - Serrulastra (Serrulastra) laevissima Nordsieck, 1981; M-O - holotype (NHMW 1979/2083/0009); P - paratype (NHMW 1979/2083/0010). - Q-R, S - Serrulastra (Serruplica) falkneri Nordsieck, 1981; Q-R - holotype (NHMW 1979/2083/0006); S - paratype (NHMW 1979/2083/0007). • T, U - Cochlodina (Miophaedusa) oppoliensis Nordsieck, 1981; T - holotype (NHMW 1979/2083/0012); U - paratype (NHMW 1979/2083/0013). • V-W - Constricta sp. (NHMW 1979/2083/0037). 


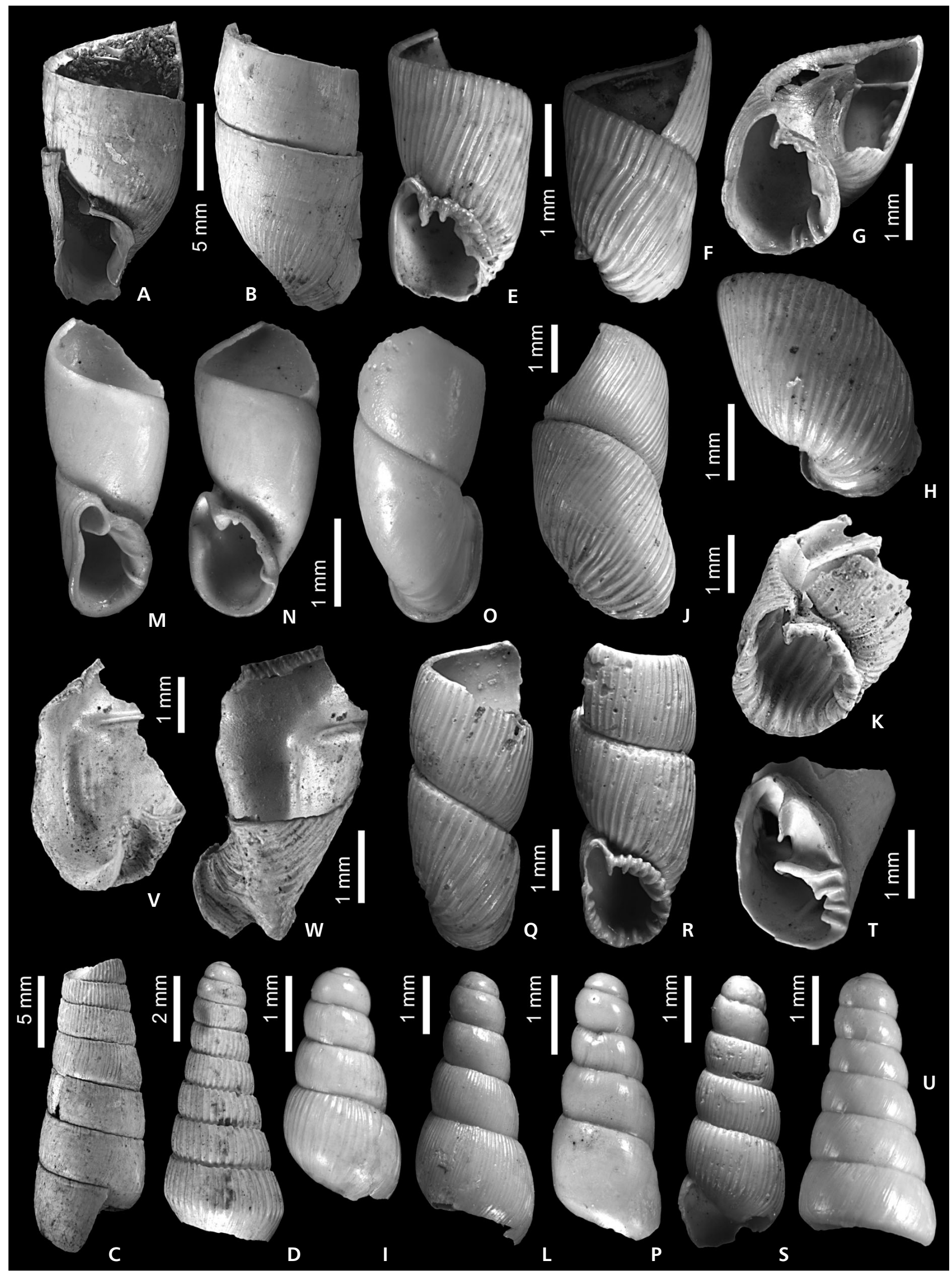


Dimensions. - Diameter: $1.5 \mathrm{~mm}$, height: $2.2 \mathrm{~mm}$.

Remarks. - Andreae (1902b) mentioned this species from Nowa Wieś Królewska at Opole but did not illustrate it. The comparison with specimens from the Burdigalian type locality Tuchořice, discussed by Harzhauser et al. (2014a), fully confirmed the identification and revealed even a completely identical microsculpture. Sculpture, microsculpture and general morphology reveal a close relationship with $N$. lineolata and therefore support a placement in Negulopsis Nordsieck, 2014.

Occurrence. - Originally described from the early Miocene of Tuchořice (Czech Republic) (Harzhauser et al. 2014a). The record from the middle Miocene of Nowa Wieś Królewska at Opole (Poland) is the youngest known occurrence of this species.

Superfamily Clausilioidea Gray, 1855

Note. - The generic assignments of species within this superfamily follow Nordsieck (1981a, b, 2000). All the species from Nowa Wieś Królewska were described and discussed in detail by Nordsieck (1981a) and Schnabel (2006).

Family Filholiidae Wenz, 1923

\section{Genus Triptychia Sandberger, 1875}

Type species. - Clausilia antiqua von Zieten, 1832; by subsequent designation by Wenz (1923). Early Miocene, Germany.

\section{Triptychia margaretae Andreae, 1904} Figure 8A-D

1902a Clausilia (Triptychia) cf. suevica Sandberger. - Andreae, p. 6.

1902b Triptychia n. sp. aff. suevica. - Andreae, p. 20.

1903 Triptychia n. sp. aff. suevica Sandb. - Andreae, p. 541.

*1904a Triptychia margaretae Andreae; Andreae, p. 12, text-fig. 12.

1904b Triptychia margaretae Andreae. - Andreae, p. 251.

1923 Triptychia (Triptychia) margaretae Andreae. Wenz, p. 815.

2006 Triptychia (Triptychia) margaretae Andreae 1904.Schnabel, p. 155, pl. 5, figs 59-61.

2016 Triptychia margaretae. - Höltke et al., p. 235.

Material. - 45 fragmentary specimens (NHMW 2017/0092/00565).
Dimensions. - Largest fragment: diameter: $8 \mathrm{~mm}$; complete specimen: diameter: $9.2 \mathrm{~mm}$, height: $41 \mathrm{~mm}$ (from Andreae 1904a, text-fig. 12)

Remarks. - This species was revised and described by Schnabel (2006). It is well represented in the NHMW collection and thus seems to have been a frequent species.

Occurrence. - Only known from Nowa Wieś Królewska at Opole (Poland).

Family Clausiliidae Gray, 1855

\section{Genus Serrulella Nordsieck in Zilch, 1978}

Type species. - Serrulina truci Nordsieck, 1972; by original designation. Pliocene, Germany.

\section{Serrulella andreaei Nordsieck, 1981}

Figure 8E-I

*1981a Serrulella andreaei n. sp.; Nordsieck, p. 66, pl. 7, figs 1,2 , text-fig. 1 .

1981b [Serrulella] andreaei H. Nordsieck 1981. - Nordsieck, p. 98.

2000 [Serrulella] andreaei H. Nordsieck 1981. - Nordsieck, p. 2.

2007 [Serrulella] andreaei H. Nordsieck 1981. - Nordsieck, p. 126.

2016 Serrulella andreaei. - Höltke et al., p. 235.

Material. - Holotype: NHMW 1979/2083/0001 (Fig. 8G, H); paratypes: 6 spire fragments, 6 aperture fragments (NHMW 1979/2083/0002); 1 clausiliar plate (NHMW 1979/2083/0003); NHMW 1979/2083/0004 (Fig. 8I), same specimen as illustrated in Nordsieck (1981a, pl. 7, fig. 2).

Dimensions. - Holotype: diameter: $2.3 \mathrm{~mm}$, height: $3.4 \mathrm{~mm}$; diameter: $1.9 \mathrm{~mm}$ height: $3.6 \mathrm{~mm}$ (Fig. 8E, F); estimated height: 9-12 mm (Nordsieck 1981a).

Remarks. - For description and discussion see Nordsieck (1981a).

Occurrence. - Only known from Nowa Wieś Królewska at Opole (Poland).

\section{Serrulella multiplicata Nordsieck, 1981}

Figure 8J-L

*1981a Serrulella multiplicata n. sp.; Nordsieck, p. 67, pl. 7, figs 3,4 .

1981b [Serrulella] multiplicata H. Nordsieck 1981. - Nordsieck, p. 98. 
2000 [Serrulella] multiplicata H. Nordsieck 1981. - Nordsieck, p. 2.

2007 [Serrulella] multiplicata H. Nordsieck 1981. - Nordsieck, p. 126.

2016 Serrulella multiplicata. - Höltke et al., p. 235.

Material. - Paratypes: 3 spire fragments (NHMW 1979/2083/0004), 5 aperture fragments (NHMW 1979/2083/0005); NHMW 1979/2083/0004 (Fig. 8L), same specimen as illustrated in Nordsieck (1981a, pl. 7, fig. 4).

Dimensions. - Diameter: $2.7 \mathrm{~mm}$, height: $5.9 \mathrm{~mm}$ (Fig. 8J, NHMW 1979/2083/0005); estimated height: 12-16 mm (Nordsieck 1981a).

Remarks. - For description and discussion see Nordsieck (1981a).

Occurrence. - Only known from Nowa Wieś Królewska at Opole (Poland).

\section{Genus Serrulastra Nordsieck, 1981}

Type species. - Clausilia amphiodon Reuss, 1861; original designation. Early Miocene, Czech Republic.

\section{Serrulastra (Serrulastra) laevissima Nordsieck, 1981} Figure 8M-P

*1981a Serrulastra (Serrulastra) laevissima n. sp.; Nordsieck, p. 68, pl. 7, figs 5, 6, text-fig. 2.

1981b [Serrulastra] laevissima H. Nordsieck 1981. - Nordsieck, p. 98.

2000 [Serrulastra] laevissima H. Nordsieck 1981. - Nordsieck, p. 2.

2007 [Serrulastra (Serrulastra)] laevissima H. Nordsieck 1981. - Nordsieck, p. 127.

2016 Serrulastra laevissima. - Höltke et al., p. 235.

Material. - Holotype (NHMW 1979/2083/0009); paratypes: 26 aperture fragments, 8 spire fragments (NHMW 1979/2083/0010), 2 clausiliar plates (NHMW 1979/2083/0011); NHMW 1979/2083/0010 (Fig. 8P), same specimen as illustrated in Nordsieck (1981a, pl. 7, fig. 6).

Dimensions. - Holotype: diameter: $1.4 \mathrm{~mm}$, height: $3.0 \mathrm{~mm}$ (Fig. 8M, O); estimated height: 6-9 mm (Nordsieck 1981a).

Remarks. - For description and discussion see Nordsieck (1981a).

Occurrence. - Only known from Nowa Wieś Królewska at Opole (Poland).

\section{Subgenus Serruplica Nordsieck, 1981}

Type species. - Clausilia ptycholarynx O. Boettger, 1877; by original designation. Middle Miocene, Czech Republic.

\section{Serrulastra (Serruplica) falkneri Nordsieck, 1981}

Figure 8Q-S

*1981a Serrulastra (Serruplica) falkneri n. sp.; Nordsieck, p. 69 , pl. 7 , figs 7,8 , text-fig. 3 .

1981b [Serrulastra (Serruplica)] falkneri H. Nordsieck 1981. - Nordsieck, p. 98.

2000 [Serrulastra (Serruplica)] falkneri H. Nordsieck 1981. - Nordsieck, p. 2.

2007 [Serrulastra (Serruplica)] falkneri H. Nordsieck 1981. - Nordsieck, p. 127.

2016 Serrulastra falkneri. - Höltke et al., p. 235.

Material. - Holotype (NHMW 1979/2083/0006); paratypes: 15 spire fragments, 2 aperture fragments (NHMW 1979/2083/0007), 1 clausiliar plate (NHMW 1979/2083/0008); NHMW 1979/2083/0007 (Fig. 8S), same specimen as illustrated in Nordsieck (1981a, pl. 7, fig. 8).

Dimensions. - Holotype: diameter: $2.0 \mathrm{~mm}$, height: $4.9 \mathrm{~mm}$ (Fig. 8Q, R); estimated height: 8-11 mm (Nordsieck 1981a).

Remarks. - For description and discussion see Nordsieck (1981a).

Occurrence. - Only known from Nowa Wieś Królewska at Opole (Poland).

\section{Genus Constricta O. Boettger, 1877}

Type species. - Clausilia (Constricta) kochi O. Boettger, 1877; by subsequent designation by Wenz (1923). Oligocene, Germany.

\section{Constricta sp.}

Figure 8V, W

$$
\begin{aligned}
& 2000 \text { [Constricta] sp. - Nordsieck, p. } 4 . \\
& 2007 \text { [Constricta] sp. - Nordsieck, p. } 127 .
\end{aligned}
$$

Material. - 2 specimens (NHMW 1979/2083/0037).

Dimensions. - Diameter: $2.7 \mathrm{~mm}$, height: $3.9 \mathrm{~mm}$.

Remarks. - A fragment of the aperture was identified by Nordsieck (1979 in coll.) as Constricta sp. and listed from Nowa Wieś Królewska in Nordsieck (2000, 2007). 
Occurrence. - Only known from Nowa Wieś Królewska at Opole (Poland).

\section{Genus Regiclausilia Nordsieck, 1981}

Type species. - Regiclausilia patula Nordsieck, 1981; by original designation. Middle Miocene, Nowa Wieś Królewska at Opole (Poland).

\section{Regiclausilia patula Nordsieck, 1981}

Figure 9G-I

*1981a Regiclausilia patula n. sp.; Nordsieck, p. 70, pl. 7, figs 9, 10, text-fig. 6 .

1981b [Regiclausilia] patula H. Nordsieck. -Nordsieck, p. 99.

2000 [Regiclausilia] patula H. Nordsieck. - Nordsieck, p. 5 .

2007 [Regiclausilia] patula H. Nordsieck. - Nordsieck, p. 127.

2016 Regiclausilia patula. - Höltke et al., p. 235.

Material. - Holotype (NHMW 1979/2083/0015); paratypes: 9 spire fragments, 4 aperture fragments (NHMW 1979/2083/0016), 1 clausiliar plate (NHMW 1979/2083/0017); NHMW 1979/2083/0016 (Fig. 9I), same specimen as illustrated in Nordsieck (1981a, pl. 7, fig. 10).

Dimensions. - Holotype: diameter: $6.3 \mathrm{~mm}$, height: $7.6 \mathrm{~mm}$ (Fig. 9G, H); estimated height: 22-27 mm (Nordsieck 1981a).

Remarks. - For description and discussion see Nordsieck (1981a).

Occurrence. - Only known from Nowa Wieś Królewska at Opole (Poland).

\section{Genus Cochlodina A. Férussac, 1821}

\section{Subgenus Miophaedusa Nordsieck, 1972}

Type species. - Clausilia (Dilataria) perforata O. Boettger, 1877; by original designation. Miocene, Czech Republic.

\section{Cochlodina (Miophaedusa) oppoliensis Nordsieck, 1981} Figure 8T, U

*1981a Cochlodina (Miophaedusa) oppoliensis n. sp.; Nordsieck, p. 71

1981a Cochlodina (Miophaedusa) oppoliensis oppoliensis n. subsp. - Nordsieck, p. 72, pl. 7, figs 11, 12, text-fig. 7. 1981b [Cochlodina (Miophaedusa)] oppoliensis H. Nordsieck 1981. - Nordsieck, p. 99.

2000 [Cochlodina (Miophaedusa)] oppoliensis H. Nordsieck 1981. - Nordsieck, p. 5.

2007 [Cochlodina (Miophaedusa)] oppoliensis H. Nordsieck 1981. - Nordsieck, p. 130.

2016 Cochlodina oppoliensis. - Höltke et al., p. 235.

Material. - Holotype (NHMW 1979/2083/0012); paratypes: 9 spire fragments, 2 aperture fragments (NHMW 1979/2083/0013, 1 clausiliar plate (NHMW 1979/2083/0014); NHMW 1979/2083/0013 (Fig. 8U), same specimen as illustrated in Nordsieck (1981a, pl. 7, fig. 12).

Dimensions. - Holotype: diameter: $2.5 \mathrm{~mm}$, height: $3.1 \mathrm{~mm}$ (Fig. 8T); estimated height: 9-12 mm (Nordsieck 1981a).

Remarks. - For description and discussion see Nordsieck (1981a).

Occurrence. - Only known from Nowa Wieś Królewska at Opole (Poland).

\section{Genus Pseudidyla O. Boettger, 1877}

\section{Subgenus Canaliciella Nordsieck, 1981}

Type species. - Pseudidyla (Canaliciella) boettgeri Nordsieck, 1981; by original designation. Middle Miocene, Nowa Wieś Królewska at Opole (Poland).

\section{Pseudidyla (Canaliciella) boettgeri Nordsieck, 1981} Figure 9D-F

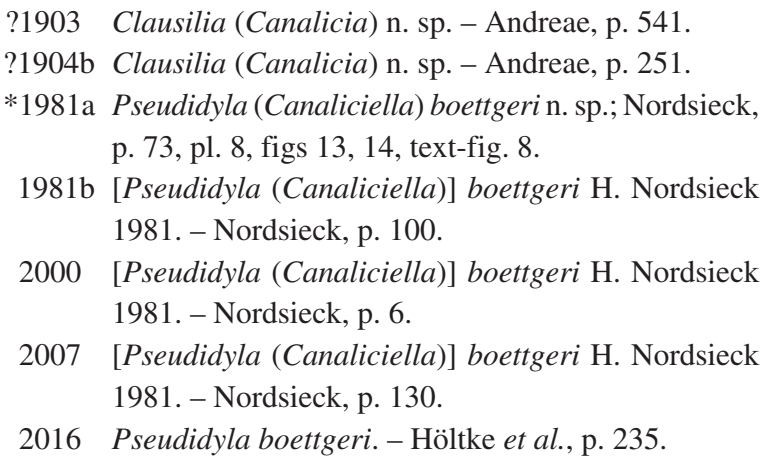
p. 73 , pl. 8 , figs 13,14 , text-fig. 8 .

1981b [Pseudidyla (Canaliciella)] boettgeri H. Nordsieck 1981. - Nordsieck, p. 100.

2000 [Pseudidyla (Canaliciella)] boettgeri H. Nordsieck 1981. - Nordsieck, p. 6.

2007 [Pseudidyla (Canaliciella)] boettgeri H. Nordsieck 1981. - Nordsieck, p. 130.

2016 Pseudidyla boettgeri. - Höltke et al., p. 235.

Material. - Paratypes: 10 aperture fragments, 35 spire fragments (NHMW 1979/2083/0021), 4 clausiliar plates (NHMW 1979/2083/0022); NHMW 1979/2083/021 (Fig. 9F), same specimen as illustrated in Nordsieck (1981a, pl. 8, fig. 14). 
Dimensions. - Diameter: $2.0 \mathrm{~mm}$, height: $3.8 \mathrm{~mm}$ (Fig. 9D, E); estimated height: 8-11 mm (Nordsieck 1981a)

Remarks. - For description and discussion see Nordsieck (1981a).

Occurrence. - Only known from Nowa Wieś Królewska at Opole (Poland).

\section{Genus Trolliella Nordsieck, 1981}

Type species. - Trolliella silesiaca Nordsieck, 1981; by original designation. Middle Miocene, Nowa Wieś Królewska at Opole (Poland).

\section{Trolliella silesiaca Nordsieck, 1981}

Figure 9A-C

*1981 Trolliella silesiaca n. sp.; Nordsieck, p. 74, pl. 8, figs 15, 16, text-fig. 10.

1981b [Trolliella] silesiaca H. Nordsieck 1981. - Nordsieck, p. 100.

2000 [Trolliella] silesiaca H. Nordsieck 1981. - Nordsieck, p. 6.

2007 [Trolliella] silesiaca H. Nordsieck 1981. - Nordsieck, p. 130.

2016 Trolliella silesiaca. - Höltke et al., p. 235.

Material. - Holotype (NHMW 1979/2083/0018); paratypes: 17 spire fragments, 6 aperture fragments (NHMW 1979/2083/0019), 2 clausiliar plates (NHMW 1979/2083/0020); NHMW 1979/2083/019 (Fig. 9C), same specimen as illustrated in Nordsieck (1981a, pl. 8, fig. 16).

Dimensions. - Holotype: diameter: $2.9 \mathrm{~mm}$, height: $5.0 \mathrm{~mm}$ (Fig. 9A, B); estimated height: 11-15 mm (Nordsieck 1981a).

Remarks. - For description and discussion see Nordsieck (1981a).

Occurrence. - Only known from Nowa Wieś Królewska at Opole (Poland).

"Testacelloid group" (not monophyletic; see Nordsieck, 2017 for discussion)

Family Oleacinidae H. Adams \& A. Adams, 1855

\section{Genus Pseudoleacina Wenz in K. Fischer \& Wenz, 1914}

Type species. - Achatina sandbergeri Thomä, 1845; by original designation. Late Oligocene, Germany.
Pseudoleacina fossilis (Andreae, 1902)

Figure 9M, N

*1902b Oleacina (Salasiella) fossilis n. sp.; Andreae, p. 6 (pars), text-fig. 1a [non $1 \mathrm{~b}=$ Pseudoleacina rakosdensis (Gaál, 1910)].

1903 [Oleacina] (Salasiella) fossilis n. sp. - Andreae, p. 540 (pars).

1904a Oleacina (Salasiella) fossilis m. - Andreae, p. 16 (pars).

1904b Oleacina (Salasiella) fossilis m. - Andreae, p. 250 (pars).

1907 Poiretia fossilis (Andreae). - Pilsbry, p. 24 (pars).

1923 Poiretia (Pseudoleacina) fossilis (Andreae). Wenz, p. 858 (pars).

2016 Pseudoleacina fossilis. - Höltke et al., p. 235 (pars).

Material. - 26 specimens (NHMW 2017/0092/0063).

Dimensions. - Diameter: $1.8 \mathrm{~mm}$, height: $3.9 \mathrm{~mm}$ (Fig. 9N); diameter: $1.6 \mathrm{~mm}$, height: $3.9 \mathrm{~mm}$ (Fig. 9M).

Description. - Small olivoid shell of three whorls with narrow but incised suture, dome-shaped spire and moderately slender last whorl. Protoconch very low domical with immersed initial part; transition into teleoconch indistinct. Spire whorl convex with maximum diameter closed to lower suture. Last whorl feebly convex with slowly contracting base; maximum diameter in upper third. Aperture moderately wide, with sharp posterior angulation and broadly convex base. Outer lip thin, nearly straight. Shell surface smooth aside from weak growth lines on last whorl and especially on base. Columella short, straight, anteriorly truncated with weakly incised anterior canal; parietal region faintly concave. Inner lip narrow, reflected as thin sheet along columella and fading out on parietal region.

Remarks. - Andreae (1902b) seems to have mixed two species in his description of Oleacina fossilis. He provided two illustrations of which text-fig. 1a agrees with his description, in which he mentioned a small shell of three whorls with short and obtuse spire. In addition, he illustrated a slender shell with more acute spire as text-fig. $1 \mathrm{~b}$. Andreae (1902b) described also growth lines on the last whorl, which tend to be more prominent towards the upper suture. These features - slender shape, higher spire and axial ribs close to the suture - agree with Pseudoleacina rakosdensis (Gaál, 1910) as described herein.

Pseudoleacina producta (Reuss in Reuss \& Meyer, 1849), from the early Miocene of Tuchořice, is much larger and has an acute spire.

Occurrence. - Only known from Nowa Wieś Królewska at Opole (Poland). 


\section{Pseudoleacina rakosdensis (Gaál, 1910) Figure 90-R}

1902b Oleacina (Salasiella) fossilis Andreae. - Andreae, p. 6 (pars), text-fig. $1 \mathrm{~b}[$ non $1 \mathrm{a}=$ Pseudoleacina fossilis (Andreae, 1902)].

1903 [Oleacina] (Salasiella) fossilis n. sp. - Andreae, p. 540 (pars).

1904a Oleacina (Salasiella) fossilis m. - Andreae, p. 16 (pars).

1904b Oleacina (Salasiella) fossilis m. - Andreae, p. 250 (pars).

1904b Oleacina (Boltenia) sp. - Andreae, p. 250.

1907 Poiretia fossilis (Andreae). - Pilsbry, p. 24 (pars).

*1910 Oleacina rákosdensis n. sp.; Gaál, p. 45, pl. 3, fig. 2.

1923 Poiretia (Pseudoleacina) fossilis (Andreae). Wenz, p. 858 (pars).

1923 Poiretia (Pseudoleacina) rákosdensis (Gaál). Wenz, p. 863.

non 2006 Pseudoleacina (Pseudoleacina) rakosdensis (Gaál). - Kókay, p. 85, pl. 33, figs 12, 13, text-fig. 13.

2016 Pseudoleacina fossilis. - Höltke et al., p. 235 (pars).

Material. - 12 specimens (NHMW 2017/0092/0064).

Dimensions. - Juvenile specimen: diameter: $1.8 \mathrm{~mm}$, height: $3.9 \mathrm{~mm}$; largest adult specimen: diameter: $4.3 \mathrm{~mm}$, height: $\sim 13 \mathrm{~mm}$ (all specimens are fragmented).

Description. - Medium-sized, fragile, slender olivoid shell of 5 whorls. Protoconch high conical, comprising two smooth whorls; first protoconch whorl domical with immersed initial part; second protoconch whorl high, initially weakly convex but later increasingly convex with periphery in lower third; suture between both whorls oblique. Transition into teleoconch indicated by onset of weakly prosocyrt axial ribs, which are most prominent along upper suture. Last whorl slender conical; maximum diameter slightly below incised, straight suture. Tips of axial ribs may form delicate subsutural cord on last whorl. Aperture very narrow, drop-shaped; columella short, strongly twisted, anteriorly truncated, with deep concavity; parietal region nearly straight. Inner lip very thin, indistinct sheet, restricted to lower part of columella, rarely preserved; outer lip thin.

Remarks. - As discussed above, Andreae (1902b) mixed juvenile specimens of this species with Pseudoleacina fossilis, which clearly differs in its dome-shaped spire, smooth last whorl and smaller size. Some fragments of this species have been treated as Oleacina (Boltenia) sp. by Andreae (1902b) as he discussed the relation with morphologically similar Pseudoleacina sandbergeri (Thomä, 1845), P. subsulcosa (Thomä, 1845) and P. producta (Reuss in Reuss \& Meyer, 1849). Pseudoleacina producta, from the early Miocene of Tuchořice, develops also subsutural axial ribs, but differs in its much larger size, and the very high and slender spire. Pseudoleacina sandbergeri and P. subsul$\cos a$, from the Oligocene and early Miocene of Germany, are distinctly broader and have higher spires.

Occurrence. - Originally described from the Sarmatian of Rákosd (= Răcăștia) in Romania; this is the first record of this species from the middle Miocene of Nowa Wieś Królewska at Opole (Poland). The occurrence from the Sarmatian of Várpalota (Hungary), reported by Kókay (2006), represent another species, which differs in its stout-domical spire and the weaker axial ribs.

\section{Oleacinidae gen. et sp. indet.}

1902b Spiraxis n. sp. - Andreae, p. 14.

1903 Spiraxis n. sp. - Andreae, p. 541.

1904a Spiraxis n. sp. - Andreae, p. 17.

1904b Spiraxis n. sp. - Andreae, p. 251.

Material. - No material available.

Remarks. - Andreae (1902b) mentioned a single spire fragment with columellar lamella. He compared the species with Spiraxis bickhardti O. Boettger, 1896, from the early Miocene of Germany, and emphasized the size difference between both species (probably referring to the smaller size of the Polish species, without clearly stating this). Spiraxis bickhardti is little known species as well, based on an internal cast, which has never been illustrated. Wenz (1923) tentatively listed it as Pseudoleacina. Whether the Polish species can be placed in this genus as well remains unclear.

"Punctoid group" (not monophyletic; see Nordsieck, 2017 for discussion)

Punctidea sensu lato (Punctidea + Helicodiscidae)

Family Punctidae Morse, 1864

Figure 9. Clausiliidae, Oleacinidae, Punctidae and Discidae. • A-B, C - Trolliella silesiaca Nordsieck, 1981; A-B - holotype (NHMW 1979/2083/0018); C - paratype (NHMW 1979/2083/019). • D-E, F - Pseudidyla (Canaliciella) boettgeri Nordsieck, 1981; D-E - paratype (NHMW 1979/2083/0021); F - paratype (NHMW 1979/2083/021). G-H, I - Regiclausilia patula Nordsieck, 1981; G-H - holotype (NHMW 1979/2083/0015); I - paratype (NHMW 1979/2083/0016). • J-L - Punctum propygmaeum Andreae, 1904 (NHMW 2017/0092/0079). • M, N - Pseudoleacina fossilis (Andreae, 1902) (NHMW 2017/0092/0063). • O, P, Q-R - Pseudoleacina rakosdensis (Gaál, 1910) (NHMW 2017/0092/0064). • S-T - Discus solarioides (Sandberger, 1872) (NHMW 2017/0092/0080). U, V, W-X - Discus sp. (NHMW 2017/0092/0081). 


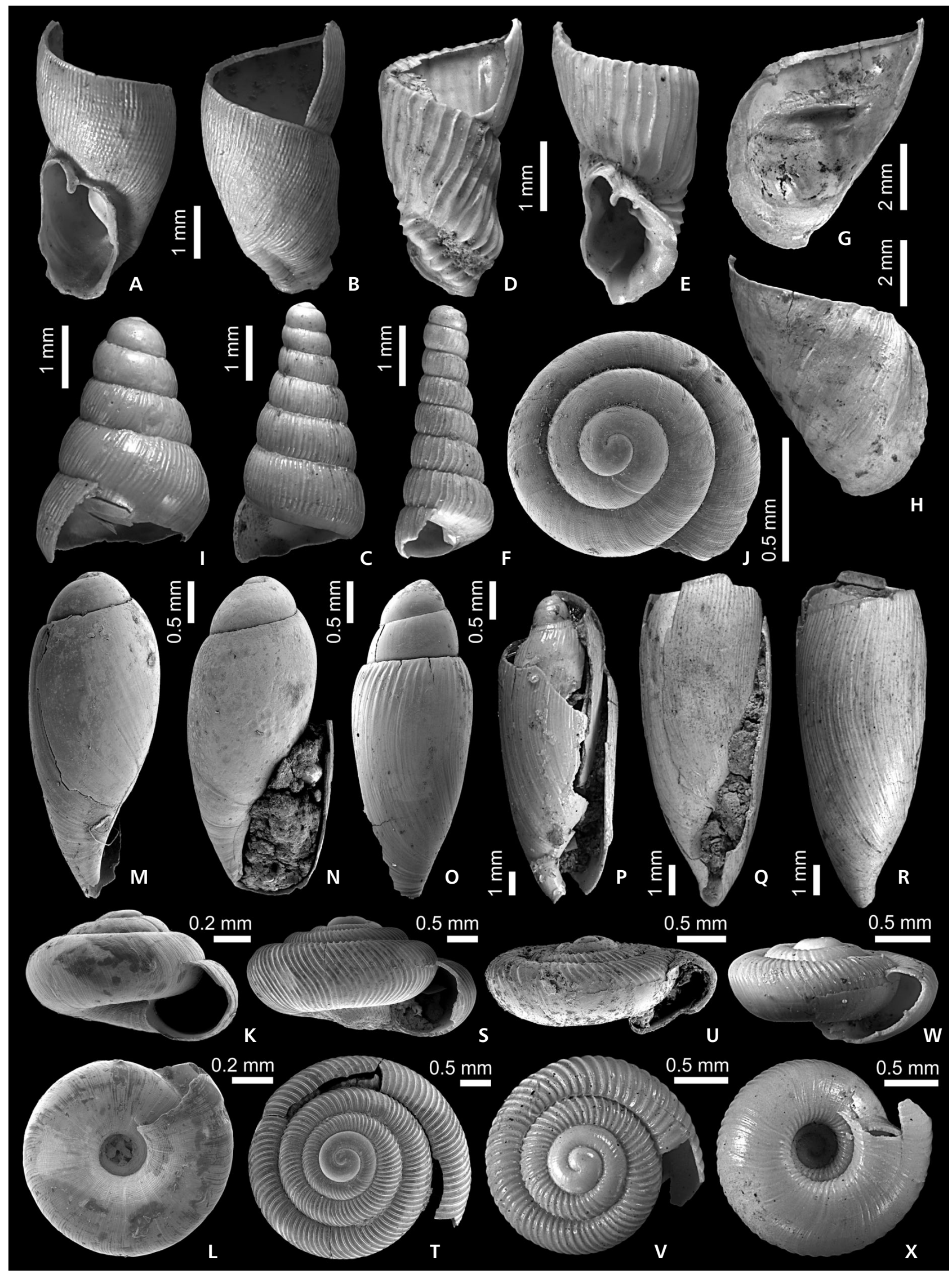




\section{Genus Punctum Morse, 1864}

Type species. - Helix minutissima Lea, 1841; by monotypy. Recent, North America.

\section{Punctum propygmaeum Andreae, 1904}

Figure $9 \mathrm{~J}-\mathrm{L}$

*1904a Punctum propygmaeum Andreae; Andreae, p. 6, text-fig. 4.

1904b Punctum propygmaeum Andreae. - Andreae, p. 251.

1923 Punctum propygmaeum propygmaeum Andreae. Wenz, p. 349

2014a Punctum propygmaeum Andreae, 1904, - Harzhauser et al., p. 871, figs 12a-e.

2016 Punctum propygmaeum. - Höltke et al., p. 235.

Material. - 2 specimens (NHMW 2017/0092/0079).

Dimensions. - Diameter: $1.05 \mathrm{~mm}$, height: $0.7 \mathrm{~mm}$ (subadult specimen; Fig. 9J-L).

Remarks. - This species was described in detail by Harzhauser et al. (2014a). The status of the various Punctum propygmaeum records and putatively related species remained dubious so far, because no SEM pictures were available from Nowa Wieś Królewska at Opole, which is the type locality of this species. Based on the new data, the occurrences from Tuchořice (Czech Republic) described by Harzhauser et al. (2014a) are clearly conspecific with those from Nowa Wieś Królewska. Punctum parvulum Gottschick, 1920, from the middle Miocene of Steinheim in Germany (Finger 1998) and Gratkorn in Austria (Harzhauser et al. 2008), differs in its coarser growth lines and the broader and more prominent striae on the protoconch.

Occurrence. - Burdigalian of Tuchořice (Czech Republic) and middle Miocene of Nowa Wieś Królewska at Opole (Poland). Additional occurrences are recorded from the Sarmatian of Rákosd (= Răcăștia) in Romania (Gaál 1910) and Lopushna in Ukraine (Prysyazhniuk 2016) and the Maeotian of Orikhivk in Ukraine (Prysyazhniuk 2015b). Like the occurrences in the late Miocene of the Vienna Basin (Lueger 1981) and the Pliocene (or Pleistocene) of Cessey-sur-Tille in France (Schlickum 1975), these records will need confirmation.
Family Helicodiscidae Pilsbry in H. B. Baker, 1927

\section{Genus Helicodiscus Morse, 1864}

Type species. - Helix lineata Say, 1817 [= Helicodiscus parallelus (Say, 1821); non Helix lineata Olivi, 1792]; by monotypy. Recent, North America.

\section{Helicodiscus roemeri (Andreae, 1902)}

Figure 10A, B

1830 [Helix] depressa m. - Eichwald, p. 215 (non Helix depressa Montagu, 1803).

*1902b Hyalinia (Gyralina) roemeri n. sp.; Andreae, p. 9, text-fig. 3.

1903 [Hyalinia] (Gyralina n. subg.) Roemeri n. sp. - Andreae, p. 540.

1904a Hyalinia (Gyralina) roemeri m. - Andreae, p. 17.

1904b Hyalinia (Gyralina n. sbg.) roemeri m. - Andreae, p. 250.

1923 Oxychilus (Gyralina) roemeri (Andreae). - Wenz, p. 288 (cum syn.).

1942 Gyralina roemeri (Andreae). - Wenz \& Edlauer, p. 93, pl. 4, fig. 12.

1997 Helicodiscus (Helicodiscus) depressus (Eichwald, 1830). - Stworzewicz \& Prisyazhnyuk, p. 202, figs 1-4 (cum syn.) (non Montagu, 1803).

2004 Helicodiscus roemeri (Andreae). - Harzhauser \& Binder, p. 22, pl. 9, figs 5, 6.

2013 Helicodiscus (Helicodiscus) roemeri (Andreae, 1902). - Stworzewicz et al., p. 193, fig. 5g.

2015 Helicodiscus roemeri (Andreae, 1902). - Harzhauser et al., p. 36, pl. 5, figs 10-12.

2016 Oxychilus (Gyralina) roemeri. - Höltke et al., p. 235.

Material. - 5 specimens (NHMW 2017/0092/0082).

Dimensions. - Diameter: $2.9 \mathrm{~mm}$, height: $1.3 \mathrm{~mm}$ (Fig. 10B); diameter: $1.9 \mathrm{~mm}$, height: $0.9 \mathrm{~mm}$ (Fig. 10A).

Remarks. - This species was described and discussed in detail by Stworzewicz \& Prisyazhnyuk (1997), Stworzewicz et al. (2013) and Harzhauser et al. (2015), who discussed also nomenclatorial issues.

Figure 10. Helicodiscidae, unassigned limacoid family and Pristilomatidae. • A, B - Helicodiscus roemeri (Andreae, 1902) (NHMW 2017/0092/0082). - C-E, F-G, H, I, J-K - Neubertella pulchra sp. nov.; C-E - holotype (NHMW 2017/0092/0089); F-G - paratype (NHMW 2017/0092/0091); H - paratype (NHMW 2017/0092/0093); I - paratype (NHMW 2017/0092/0090); J-K - paratype (NHMW 2017/0092/0092). • L-N, O-Q, R-S Mennoia sculpturata sp. nov.; L-N - paratype (NHMW 2017/0092/0060); O-Q - holotype (NHMW 2017/0092/0059); R-S - paratype (NHMW 2017/0092/0061). - T-U, V-W, X-Y, Z-Aa - Eurocystina nordsiecki sp. nov.; T-U - paratype (NHMW 2017/0092/0068); V-W - paratype (NHMW 2017/0092/0069); X-Y - paratype (NHMW 2017/0092/0067); Z-Aa - holotype (NHMW 2017/0092/0066). 


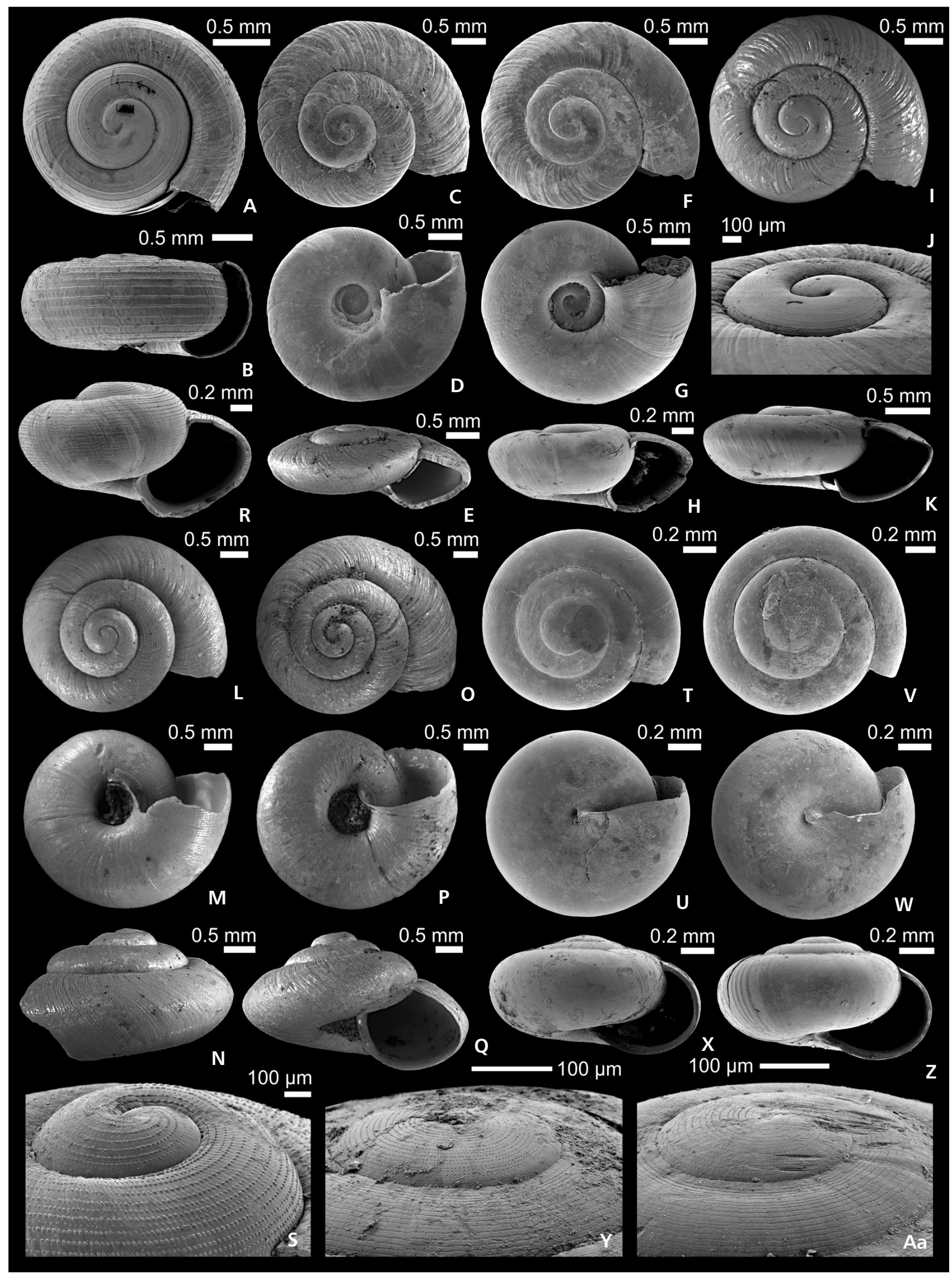


Occurrence. - Originally described as Helix depressa from the middle Miocene of Hołowczyńce in Ukraine by Eichwald (1830) and as Hyalina roemeri from the middle Miocene of Nowa Wieś Królewska at Opole. Additional occurrences are reported from the middle Miocene of Zwierzyniec and Bełchatów (Poland) and Moldova (Stworzewicz \& Prisyazhnyuk 1997, Stworzewicz et al. 2013) and from the late Miocene of the Vienna Basin (Richardshof and Eichkogel, Austria) and Öcs (Hungary) (Schlickum 1979b, Harzhauser \& Binder 2004). The stratigraphically youngest record was described by Harzhauser et al. (2015) from the Messinian of Moncucco Torinesi (Italy).

Family Discidae Thiele, 1931 (1866)

\section{Genus Discus Fitzinger, 1833}

Type species. - Helix ruderata Hartmann, 1821; by subsequent designation by Gray (1847). Recent, Europe.

\section{Discus solarioides (Sandberger, 1872)}

Figure 9S, T

*1872 Patula solarioides A. Braun; Sandberger, captions to pl. 28, fig. 7-7c.

1911 Patula (Charopa) costata Gottschick. - Gottschick, p. 501, pl. 7, figs $15 \mathrm{a}-\mathrm{c}$.

1923 Goniodiscus (Goniodiscus) costatus (Gottschick). Wenz, p. 326.

2013 Discus costatus (Gottschick, 1911). - Stworzewicz et al., p. 193, figs 5d-f.

2016a costata Gottschick, 1911, Patula (Charopa). - Salvador et al., p. 22, pl. 3, figs 1a-c.

2017 Discus solarioides (Sandberger, 1872). - Neubauer et al., p. 753, figs 9a-g (cum syn.).

Material. - 5 specimens (NHMW 2017/0092/0080).

Dimensions. - Largest specimen: diameter: $3.7 \mathrm{~mm}$, height: $1.8 \mathrm{~mm}$ (Fig. 9S, T).

Description. - Small discoidal shell with low conical spire and about 4 whorls. Protoconch comprising 1.25 convex whorls of $780 \mu \mathrm{m}$ diameter; smooth aside from spiral threads and few radial wrinkles along upper suture. Teleoconch whorls only slowly increasing in width with convex tops, suture incised; sculpture consisting of densely spaced, regular axial ribs, prosocline to slightly prosocyrt in apical view ranging around 85 on last preserved whorl. Periphery convex, maximum diameter slightly above mid-whorl; slightly angulated in subadult shells but regularly convex in adult stages. Axial ribs continuous on periphery, very prominent, sigmoidal in lateral view. Base strongly convex passing rapidly into funnel-shaped, moderately wide, perspective umbilicus. Axial ribs very distinct on base, sigmoidal, rarely bifurcating, increasing in strength in circum-umbilical area. Aperture oblique ear-shaped; peristome not preserved.

Remarks. - Neubauer et al. (2017) discussed this species in detail and clarified nomenclatorial issues, showing that $\mathrm{Pa}$ tula (Charopa) costata Gottschick, 1911 is a junior objective synonym of Patula solarioides Sandberger, 1872. It is reminiscent of Discus euglyphoides (Sandberger, 1875), which has comparably prominent axial ribs on the base. As already pointed out by Gottschick (1911), D. euglyphoides differs in its prominent keel on the last whorl (see Schlickum 1976) and the lower number of axial ribs on the whorl tops (60-65), which result in broader interspaces between the ribs.

Occurrence. - Originally described from the middle Miocene of Steinheim (Germany). Further occurrences are recorded from the middle Miocene of Nowa Wieś Królewska at Opole (Poland), the Sarmatian of Gratkorn (Austria), Zwierzyniec (Poland) and Vračević (Serbia) (Harzhauser et al. 2008, Stworzewicz et al. 2013, Neubauer et al. 2017).

\section{Discus sp.}

Figure 9U-X

Material. - 13 specimens (NHMW 2017/0092/0081).

Dimensions. - Largest specimen: diameter: $2.7 \mathrm{~mm}$, height: $1.3 \mathrm{~mm}$; diameter: $2.45 \mathrm{~mm}$, height: $1.2 \mathrm{~mm}$ (Fig. 9U).

Description. - Small discoidal shell of about 3.5-4 whorls with nearly flat spire aside from the slightly protruding protoconch. Protoconch consisting of 1.3 convex whorls of $750 \mu \mathrm{m}$ diameter; smooth aside from faint spiral threads in abapical half and short radial wrinkles along the upper suture. Transition into teleoconch indicated by onset of prominent, regular axial ribs separated by slightly broader interspaces. Axial ribs orthocline to slightly prosocline/ prosocyrt in apical view, counting about 70 on last preserved whorl. Teleoconch whorls moderately convex with deep suture, only very slowly increasing in width. Axial ribs fade out soon on periphery. Maximum diameter in upper third of whorl, being only weakly convex below. Base convex, rapidly passing into moderately wide, funnel-shaped, perspective umbilicus. Sculpture consisting of delicate axial ribs, which are slightly stronger in circum-umbilical area. Aperture oblique ear-shaped; peristome not preserved.

Remarks. - In the material from Nowa Wieś Królewska, the partly fragmented specimens of the co-occurring 
Discus solarioides (Sandberger, 1872) and Discus sp. are quite similar and could be confused. The nearly flat spire Discus sp. and its much weaker sculpture on the base, however, allow a separation. Among the Miocene Discidae, this species is somewhat reminiscent of Discus pleuradrus (Bourguignat, 1881) in sculpture; the depressed spire, however, differs markedly from that of $D$. pleuradrus.

Occurrence. - Middle Miocene of Nowa Wieś Królewska at Opole (Poland).

Non-helicarinoid Limacoidea

Family unknown

\section{Genus Mennoia gen. nov.}

Type species. - Mennoia sculpturata sp. nov.

Etymology. - In honor of Menno Schilthuizen (Naturalis Biodiversity Center and Leiden University), specialist for continental molluses.

Diagnosis. - Small, depressed turbiniform shell with angulated last whorl, bulgy spire whorls and wide perspective umbilicus. Protoconch and teleoconch entirely covered by delicate but well-defined and regular beads arranged in spiral rows on protoconch and in spirals and along growth lines on teleoconch.

Remarks. - This new genus is characterized by its outstanding sculpture of spiral rows of delicate beads, the depressed turbiniform shape and wide umbilicus. Its overall shape is reminiscent of some species of the Australasian euconulid genera Coneuplecta Möllendorff, 1893, Liardetia Gude, 1913 and Dasyconus Baker, 1938 as described by Baker (1938), Hyman \& Ponder (2010) and Kawase et al. (2011, 2012). Especially Coneuplecta japonica Habe, 1964 develops similarly depressed-bulgy whorls with slight angulation (but with higher spire). Although several species of these genera may develop spiral threads, we are not aware of species with spirally arranged beads on the teleoconch. Moreover, the wide umbilicus of Mennoia would be untypical for these genera. A comparable microsculpture on protoconch and teleoconch is also described for Malaysian species of the euconulid Kaliella Blanford, 1863 by Vermeulen et al. (2015), e.g. Kaliella microconus (Mousson, 1865) and Kaliella dendrophila (Van Benthem Jutting, 1950). Kaliella, however, differs in its trochiform outline and usually narrower umbilicus. Biogeographically, a closer relationship of the Miocene European genus with these tropical Australasian taxa is unlikely. Therefore, and in respect to the discussed conchological differences, a placement in Euconulidae is unlikely and the suprageneric placement of this genus remains doubtful.
Other species. - Type species only.

Occurrence. - The new genus is only known from the middle Miocene of Central Europe.

Mennoia sculpturata sp. nov.

Figure $10 \mathrm{~L}-\mathrm{S}$

1902b Hyalina (?Aegopina) sp. indet. - Andreae, p. 8.

1903 Hyalina (Aegopina) n. sp. - Andreae, p. 540.

1904a Hyalina (Aegopina) n. sp. - Andreae, p. 16.

1904b Hyalina (Aegopina) n. sp. - Andreae, p. 250.

Holotype. - NHMW 2017/0092/0059: diameter: $4.2 \mathrm{~mm}$, height: $2.6 \mathrm{~mm}$ (Fig. 10O-Q).

Paratypes. - NHMW 2017/0092/0060: diameter: 3.7 mm, height: 2.2 mm (Fig. 10L, N); NHMW 2017/0092/0061: diameter: $2.1 \mathrm{~mm}$, height: $1.2 \mathrm{~mm}$ (Fig. 10R, S).

Type horizon and locality. - Grey clayey marl ("Landschneckenmergel"), middle Miocene, late Langhian/early Serravallian (MN 6). Nowa Wieś Królewska at Opole (Poland).

Material. - 28 specimens (NHMW 2017/0092/0062).

Etymology. - Referring to the conspicuous microsculpture.

Diagnosis. - As for genus above.

Description. - Small, broad turbiniform shell. Large, low conical protoconch consisting of 1.25 convex whorls with incised suture; $1.1-1.3 \mathrm{~mm}$ diameter; initial part smooth; soon 5 prominent spiral beads of densely spaced beads set in, raising to 18 spiral rows on whorl top of last protoconch whorl; especially on upper half of whorl secondary spiral rows of weaker beads are intercalated. Microsculpture persists on periphery, base and at umbilicus of teleoconch. Teleoconch consisting of 2-2.5 whorls; first teleoconch whorl strongly convex, bulgy with deep suture. Last whorl moderately convex above rounded mid-whorl angulation, moderately convex below passing into regularly convex base. Growth lines weakly prosocyrt in apical view, strongly prosocline-sigmoidal in lateral view and orthocline on base. Umbilicus wide, perspective.

Remarks. - Andreae (1902b) already collected this species but refrained from describing it formally as new species due to insufficient material.

Occurrence. - Only known from Nowa Wieś Królewska at Opole (Poland). 


\section{Genus Neubertella gen. nov.}

Type species. - Neubertella pulchra sp. nov.

Etymology. - In honor of Eike Neubert (Natural History Museum Bern), specialist for continental molluscs.

Diagnosis. - Small, solid, discoid-lenticular, angulated shell with low spire; sculpture consisting of prominent spiral cords on protoconch continuing as disconnected spiral threads on entire shell, overriding blunt, irregular axial ribs. Umbilicus wide, perspective.

Remarks. - This genus differs from Mennoia in its prominent spiral cords on the protoconch and the lower spire. Both genera are close in respect to umbilical features and the angulated shells. The spiral cords on the protoconch and the discontinuous spiral cords overriding the radial sculpture on the teleoconch, as also present in some Pristilomatidae, such as Gyralina Andreae, 1902 and Spelaeopatula A. J. Wagner, 1922 (Dedov \& Subai 2012) but also in the Helicodiscidae (see Stworzewicz \& Prisyazhnyuk 1997, Harzhauser et al. 2015). A closer relation with Helicodiscidae or Pristilomatidae is unlikely in respect to the comparatively narrower umbilicus and/or the distinctly less tightly coiled whorls, higher spire, sloping whorl tops and angulated periphery of Neubertella.

The conspicuous protoconch and teleoconch sculpture separate Mennoia and Neubertella from Oxychilidae.

Other species. - Type species only.

Occurrence. - The new genus is only known from the middle Miocene of Central Europe.

\section{Neubertella pulchra sp. nov.}

Figure 10C-K

Holotype. - NHMW 2017/0092/0089: diameter: $3.1 \mathrm{~mm}$, height: $1.2 \mathrm{~mm}$ (Fig. 10C-E).

Paratypes. - NHMW 2017/0092/0090: diameter: 2.8 mm, height: $1.3 \mathrm{~mm}$ (Fig. 10I); NHMW 2017/0092/0091: diameter: $2.9 \mathrm{~mm}$, height: $1.2 \mathrm{~mm}$ (Fig. 10F, G); NHMW 2017/0092/0092: diameter: 2.45 mm, height: $1.1 \mathrm{~mm}$ (Fig. 10J, K); 3 specimens (NHMW 2017/0092/0093, Fig. 10H).

Type horizon and locality. - Grey clayey marl ("Landschneckenmergel"), middle Miocene, late Langhian/early Serravallian (MN 6). Nowa Wieś Królewska at Opole (Poland).

Material. - Additional paratypes: 3 specimens (NHMW 2017/0092/0093, Fig. 10H).
Etymology. - From Latin pulchra (= beautiful).

Diagnosis. - As for the genus.

Description. - Discoid-lenticular solid shell; protoconch only weakly protruding, consisting of 1.5 moderately convex whorls of $1.1 \mathrm{~mm}$ diameter, covered by 9-11 wide-spaced, continuous spiral cords; interspaces smooth. Transition into teleoconch indicated by rim and change of microsculpture. Spiral threads wavy and somewhat discontinuous; distinct growth lines along upper suture cause wavy shell surface in subsutural region of earliest teleoconch. Teleoconch comprising 1.5 whorls with moderately convex tops; suture deep; sculpture consisting of blunt, bulgy, weakly prosocyrt axial ribs of variable strengths. Ribs grade into sigmoid-prosocline growth lines below shoulder and periphery; base and umbilical area covered by prominent, slightly sigmoidal growth lines. Disconnected spiral threads continue on entire teleoconch, overriding axial sculpture, being most prominent on base. Prominent angulation marking transition from whorl top into flank, coinciding with maximum diameter; periphery below rapidly contracting, passing into moderately convex base. Umbilicus wide, perspective; umbilical area strongly convex.

Remarks. - This species is characterized by its outstanding sculpture. The slightly reminiscent co-occurring Pseudoxerotricha neudorfensis (Andreae, 1904) is clearly distinguished by the smooth protoconch and the presence of prominent hair pits. Helicodiscus roemeri (Andreae, 1902) has a similar protoconch but is readily distinguished by its depressed spire, tightly coiled shell and more prominent spiral cords on the teleoconch.

Occurrence. - Only known from Nowa Wieś Królewska at Opole (Poland).

Family Agriolimacidae H. Wagner, 1935

Agriolimacidae sp.

Figure 11A-E

? 1902b Sansania crassitesta (Reuss). - Andreae, p. 5.

? 1903 Sansania crassitesta Rss. - Andreae, p. 540.

? 1904a Sansania crassitesta (Reuss). - Andreae, p. 3.

? 1904b Sansania crassitesta (Reuss). - Andreae, p. 250.

? 2016 Limacus crassitesta. - Höltke et al., p. 235.

Material. - 38 specimens (NHMW 2017/0092/0083).

Dimensions. - Diameter: $2.1 \mathrm{~mm}$, length: $3.8 \mathrm{~mm}$, height: $1.1 \mathrm{~mm}$ (Fig. 11A, B). 
Description. - Small, solid, thick, elongate shell with sub-parallel lateral margin, regularly rounded anterior margin and broadly convex posterior margin with marked central notch left to nucleus. Nucleus at margin, slightly pointed oriented to the left. Weak concavity along posterior part of left margin in juvenile growth stages. Shell surface smooth aside from eccentric growth lines. Dorsal shell weakly convex, irregular, with slight concavities on wings left and right to nucleus. Lower shells surface very irregular, bulgy; margins often with blunt verrucose swellings.

Remarks. - This species is among the most frequent slugs in the samples from Nowa Wieś Królewska at Opole. It displays little variability in size and shape and is recognized easily. Therefore, it is surprising that Andreae (1902b) seemed to have no specimens at hand. Most probably, he discussed this species as Sansania crassitesta, referring to a species from the Burdigalian of Tuchorice. As Andreae (1904a) stated, this species was not well illustrated at that time. Topotypic material of Limacus crassitesta (Reuss, 1868) was recently described and illustrated by Harzhauser et al. (2014a). None of the slug shells from Nowa Wieś Królewska at Opole in the NHMW collection corresponds to that species, raising doubts about Andreae's identification. The presence of a notch, mentioned by Andreae (1904a), would also point to the species described herein; on the other hand, the size of $5 \mathrm{~mm}$ reported for the "crassitesta" specimens by Andreae (1904a) is on average $1 \mathrm{~mm}$ larger than observed herein.

"Limax sp." sensu Binder (2002, pl. 2, fig. 2), from the early Miocene of the Korneuburg Basin in Austria, might be a closely related species, which differs only in the broader shape, deeper posterior notch and the markedly parallel lateral margins.

Occurrence. - Only known from Nowa Wieś Królewska at Opole (Poland).

Family Gastrodontidae Tryon, 1866

\section{Genus Janulus Lowe, 1852}

Type species. - Helix calathus Lowe, 1852; by monotypy. Recent, Madeira.

\section{Janulus sp.}

Figure 11F-I

1902b Patula (Janulus) gyrorbis (v. Klein). - Andreae, p. 10 (non Helix gyrorbis Klein, 1846).

1904a Janulus gyrorbis (v. Klein). - Andreae, p. 16 (non Klein, 1846).

1904b Janulus gyrorbis (v. Klein). - Andreae, p. 250 (non Klein, 1846).
2016 Janulus gyrorbis. - Höltke et al., p. 235 (non Klein, 1846).

Material. - 1 specimen (NHMW 2017/0092/0071).

Dimensions. - Diameter: $6.1 \mathrm{~mm}$, height: $3.1 \mathrm{~mm}$.

Descriptions. - Medium-sized, tightly coiled, discoidal shell with very low conical spire; protoconch consisting of c. 0.9 smooth whorls; $780 \mu \mathrm{m}$ diameter. Teleoconch comprising 5.5 whorls, only very slowly increasing in width. Whorl tops convex with incised suture; sculpture consisting of broad, blunt, densely and regularly spaced, slightly prosocline axial ribs with convex tops; numbering $c .90$ on last whorl; separated by interspaces having about same width as ribs. Periphery convex without angulation; maximum diameter slightly above mid-whorl. Axial ribs strongly prosocline in lateral view, fading out in middle of whorl. Base moderately convex, nearly smooth aside from orthocline to weakly sigmoidal growth lines, which are reinforced around umbilicus. Umbilicus perspective, funnel-shaped, moderately wide. At least one prominent palatal plica appears in middle of whorl about a quarter whorl behind peristome; other palatal plicae might be present but are inaccessible.

Remarks. - The presence of a palatal plica supports the generic placement within Janulus. Andreae (1902b) listed this species as Patula (Janulus) gyrorbis (v. Klein), a species described from the early Miocene of Germany (Wenz 1923). Helix gyrorbis Klein, 1846, if a Janulus at all, differs clearly from the Polish species in its very wide umbilicus and depressed discoidal outline. Janulus gyrorbis sensu Sandberger $(1872,1875)$ differs in its distinctly convex base. Later, Wenz (1923, p. 305) listed the occurrence from Opole in the synonymy of Janulus supracostatus (Sandberger, 1872). As discussed by Wenz (1923, p. 304) and Moser et al. (2009), the name Patula supracostata sensu Sandberger $(1872,1875)$ contains two different species. The name became available from an illustration in Sandberger (1872, pl. 29, figs 2a-c), whereas the description in Sandberger (1875, p. 584) apparently refers to another species. However, the illustration of Janulus supracostatus in Sandberger (1872) is not accompanied by any information on (type) locality or stratum; perhaps it derives from the same region as indicated in the description of the other species (early/middle Miocene deposits of S Germany and Switzerland). The figure depicts a species, which differs from the Polish one by the lower number of axial ribs and slightly wider umbilicus.

Other fossil Janulus species were briefly discussed by Manganelli et al. (2011). Of these, Helix striata Eichwald, 1830, from the middle Miocene of Hołowczyńce (Ukraine), has a coarser sculpture than the Polish species 
and a very narrow umbilicus (see Manganelli et al. 2011 for the nomenclatorial status of this species). Janulus moersingensis Jooss, 1918, from the early/middle Miocene of Mörsingen (Germany), agrees largely in shape, size and sculpture but differs in its wider umbilicus and even lower spire (see holotype in Salvador et al. 2016a). The same features allow a separation from the Rupelian Janulus densestriatus (Klika, 1891). Janulus gottschicki (Jooss, 1912), from the middle Miocene of Steinheim, and $J$. angustiumbilicatus (Sacco, 1886), from the Pliocene of $\mathrm{N}$ Italy, are distinguished by their narrower umbilicus. Janulus austriacus Harzhauser \& Binder, 2004, from the late Miocene of the Vienna Basin, is smaller, slightly angulated and has a higher last whorl. Janulus schottleri Wenz, 1922, from the Miocene of Treis a. d. Lumda (Germany), has a conical spire, more whorls and a wider umbilicus (Wenz 1922b).

Thus, the specimen from Nowa Wieś Królewska seems to represent a new Miocene species. With respect to the completely confused status of the various Miocene Janulus species and the lack of sufficient material, however, we refrain from describing it formally as new species.

Occurrence. - Middle Miocene of Nowa Wieś Królewska at Opole (Poland).

Family Limacidae Lamarck, 1801

\section{? Genus Lehmannia Heynemann, 1863}

Type species. - Limax marginatus Müller, 1774; by monotypy. Recent, Europe.

?Lehmannia excavata (Andreae, 1904) comb. nov. Figure 11J-N

*1904a Limax excavatus n. sp. - Andreae, p. 4, text-fig. 1.

1904b Limax excavatus n. sp. - Andreae, p. 250.

1908 Limax excavatus. - Wegner, p. 112.

non 1967 Limax excavatus Andreae. - Schütt, p. 213, fig. 18.

1923 Limax excavatus Andreae. - Wenz, p. 310.

2016 Limax excavatus. - Höltke et al., p. 235.

Material. - 23 specimens (NHMW 2017/0092/0084).

Dimensions. - Diameter: $4.9 \mathrm{~mm}$, length: $7.4 \mathrm{~mm}$, height: $2.3 \mathrm{~mm}$ (Fig. 11J-L).
Description. - Large, solid, broad-elongate internal shells with sub-parallel lateral margins, moderately convex anterior margin and strongly convex posterior margin with protruding nucleus. Shell strongly thickened anteriorly, causing wedge-like outline in lateral view. Left margin with distinct concavity in juvenile growth stages. Subcentral, pointed nucleus slightly oriented to the left, separated by shallow concavity from left lateral margin. Dorsal side weakly convex with distinct growth lines. Lower side flat to faintly concave with rough surface; prominent, bulgy transversal ridge below nucleus.

Remarks. - The generic placement is tentative; the outline and sub-central nucleus are reminiscent of Lehmannia shells as described by Zilch (1959) and Schlickum (1976). Despite the difficulties to use internal shells for species-level identifications (Wiktor \& Likharev 1979, Reuse 1983); this species is very characteristic and can be recognized easily in the material from Nowa Wieś Królewska. The illustration by Andreae (1904a) is somewhat misleading due to the ovoid outline of the drawing. Moreover, Andreae (1904a) described the shells as thin, which is only true for juveniles, whereas adult specimens have strongly calcified shells.

The specimen from the Sarmatian of Hollabrunn (Austria) identified as Limax excavatus by Schütt (1967) differs considerably in the broad ovoid outline and evenly convex posterior margin and is clearly not conspecific with the Polish species.

Occurrence. - Only known from Nowa Wieś Królewska at Opole (Poland).

Family Milacidae Ellis, 1926

\section{Genus Milax Gray, 1855}

Type species. - Limax gagates Draparnaud, 1801; by subsequent designation by Fagot (1893). Recent, France.

\section{Milax oppoliensis (Andreae, 1904)}

Figure 110-W

*1904a Amalia oppoliensis n. sp.; Andreae, p. 4, text-fig. 2. 1904a Amalia oppoliensis var. ancyloides n. var.; Andreae, p. 5 , text-fig. 3 .

1904b Amalia oppoliensis n. sp. - Andreae, p. 250.

Figure 11. Agriolimacidae, Gastrodontidae, Limacidae and Milacidae. - A-B, C, D, E - Agriolimacidae sp. (NHMW 2017/0092/0083). - F-I - Janulus sp. (NHMW 2017/0092/0071). • J-L, M, N - ?Lehmannia excavata (Andreae, 1904) (NHMW 2017/0092/0084). - O, P-R, S-U, V-W - Milax oppoliensis (Andreae, 1904); O, P-R - typical specimens (NHMW 2017/0092/0086); S-U, V-W - ancyloides-morph (NHMW 2017/0092/0087). 


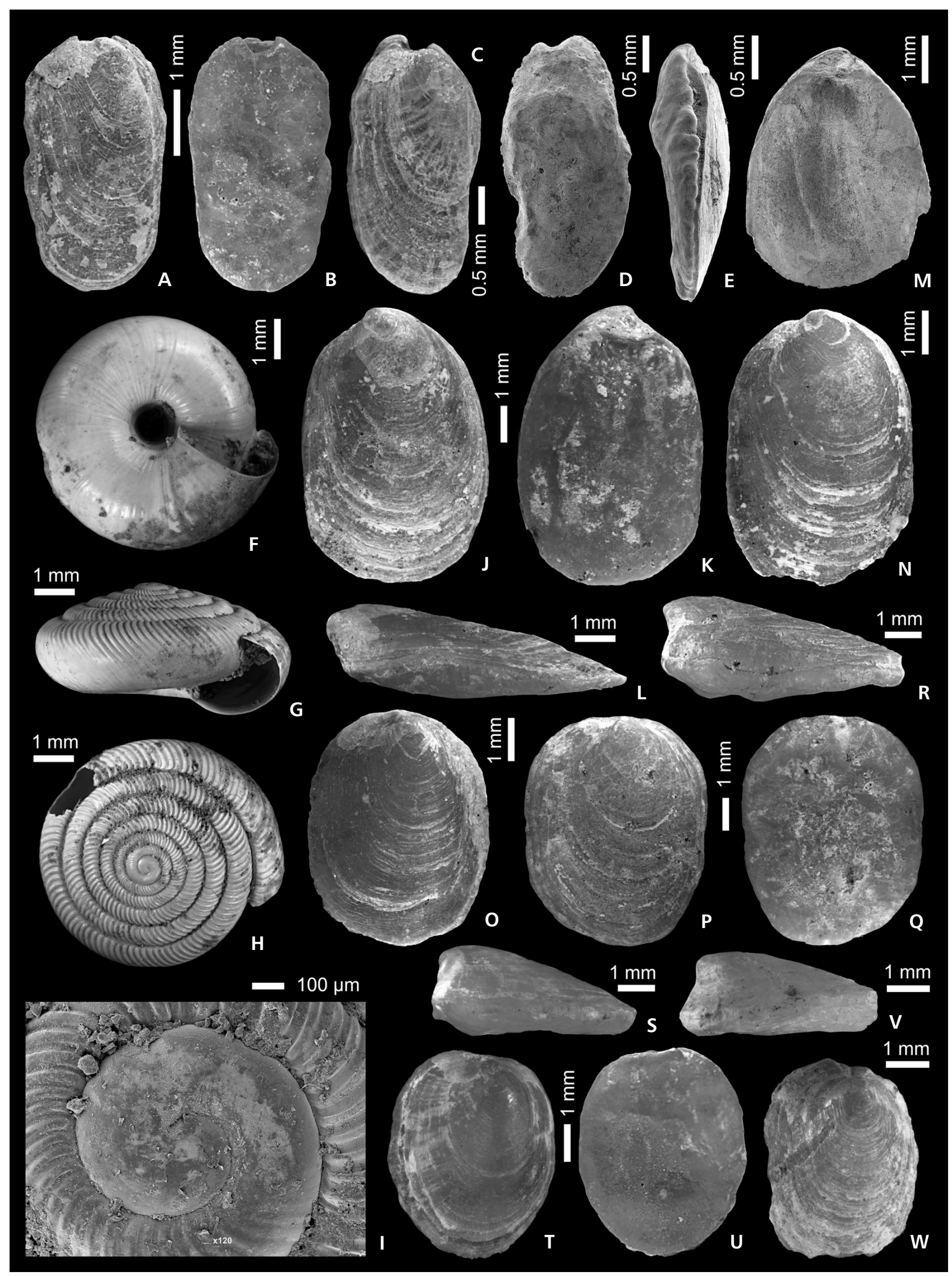


1904b [Amalia oppoliensis] var. n. ancyloides. - Andreae, p. 250.

1908 Amalia oppoliensis. - Wegner, p. 112.

1923 Milax (Milax) oppoliensis oppoliensis (Andreae). Wenz, p. 315.

1923 Milax (Milax) oppoliensis ancyloides (Andreae). Wenz, p. 315.

2016 Milax oppoliensis. - Höltke et al., p. 235.

Material. - 12 specimens (NHMW 2017/0092/0086), 2 specimens (NHMW 2017/0092/0087).

Dimensions. - Largest specimen: diameter: $5.7 \mathrm{~mm}$, length: $7.0 \mathrm{~mm}$, height: $3.0 \mathrm{~mm}$ (Fig. 11P-R); ancyloides-morph: diameter: $4.5 \mathrm{~mm}$, length: $5.5 \mathrm{~mm}$, height: $2.5 \mathrm{~mm}$ (Fig. 11S-U).

Description. - Large, solid, broad-elliptical shells with moderately convex anterior margin and nearly straight central parts of the lateral and posterior margins. Central nucleus close to margin without protruding. Shell strongly thickened in posterior part, causing wedge-like outline and concavity between nucleus and margin in lateral view. Dorsal shell surface covered by distinct, concentric growth lines; lower side flat to faintly convex with rough surface.

Remarks. - The generic placement is tentative. This species is characterized by its large size and the wedge-like outline in lateral view due to the strongly raised nucleus. Like for the other slug taxa from Nowa Wieś Królewska, the drawing in Andreae (1904a) is slightly misleading as it shows a more elongate shell with slightly protruding nucleus. Andreae (1904a) separated smaller specimens with more spherical outline as variety ancyloides (Fig. 11S-X). A comparison of growth lines of typical M. oppoliensis and those of ancyloides-morphs does not show significant differences. Most probably, the smaller shells are just subadult specimens of M. oppoliensis. "Limax sp." sensu Binder (2002, pl. 2, fig. 1), from the early Miocene of the Korneuburg Basin in Austria, is somewhat reminiscent of $M$. oppoliensis but differs in its more elongate shape.

Occurrence. - Only known from Nowa Wieś Królewska at Opole (Poland).
Family Oxychilidae Hesse, 1927 (1879)

\section{Genus Aegopinella Lindholm, 1927}

Type species. - Helix pura Alder, 1830; by original designation. Recent, Great Britain.

\section{Aegopinella depressula sp. nov. Figure $12 \mathrm{~A}-\mathrm{C}$}

Holotype. - NHMW 2017/0092/0072: diameter: $6.0 \mathrm{~mm}$, height: $1.45 \mathrm{~mm}$.

Type horizon and locality. - Grey clayey marl ("Landschneckenmergel"), middle Miocene, late Langhian/early Serravallian (MN 6). Nowa Wieś Królewska at Opole (Poland).

\section{Material. - None.}

Etymology. - Referring to the depressed outline.

Diagnosis. - Medium-sized shell with low spire and wide last whorl; flank less convex above mid-whorl than below; umbilicus moderately wide, perspective. Microsculpture of faint spiral threads on base.

Description. - Discoidal, glossy shell with nearly flat spire; protoconch smooth consisting of 1.3 whorls of $0.95 \mathrm{~mm}$ diameter. Teleoconch comprising 3.5 whorls slowly increasing in width, with moderately convex whorl tops; suture distinctly incised. Last whorl strongly widening, with maximum diameter slightly below mid-whorl; periphery strongly convex, whorl portions above and below mid-whorl slightly less convex; base slightly concave. Aperture wide. Umbilicus moderately wide, weakly widening, perspective. Upper shell surface smooth aside from delicate growth lines; faint spiral striae on base only visible in very strong magnification. Growth lines prosocyrt on whorl tops, sigmoidal-prosocline in lateral view and faintly sigmoidal-orthocline on base.

Remarks. - The co-occurring Perpolita miocaenica (Andreae, 1902) is much smaller (2.7 mm versus $6 \mathrm{~mm}$ diameter), less depressed, has a wider umbilicus and lacks a spiral sculpture. Aegopinella denudata (Reuss in Reuss \& Meyer, 1849), from the Burdigalian of Tuchořice (Czech

Figure 12. Oxychilidae and Pristilomatidae. • A-C - Aegopinella depressula sp. nov.; holotype (NHMW 2017/0092/0072). • D-F, G-I, J-K Perpolita miocaenica (Andreae, 1902) (NHMW 2017/0092/0099). • L-N, O - Aegopinella sp. (NHMW 2017/0092/0100). • P-V - Vitrea angustaeumbilicata sp. nov.; P-R - holotype (NHMW 2017/0092/0074); S-T - paratype (NHMW 2017/0092/0075); U-V - paratype (NHMW 2017/0092/0076). Note that the seemingly variable spire-height of the illustrated specimens is an artifact due to different viewing angles; moreover, Figure 12U shows a specimen with taphonomically depressed spire. • W-Y - Vitrea procrystallina (Andreae, 1902) (NHMW 2017/0092/0078). 


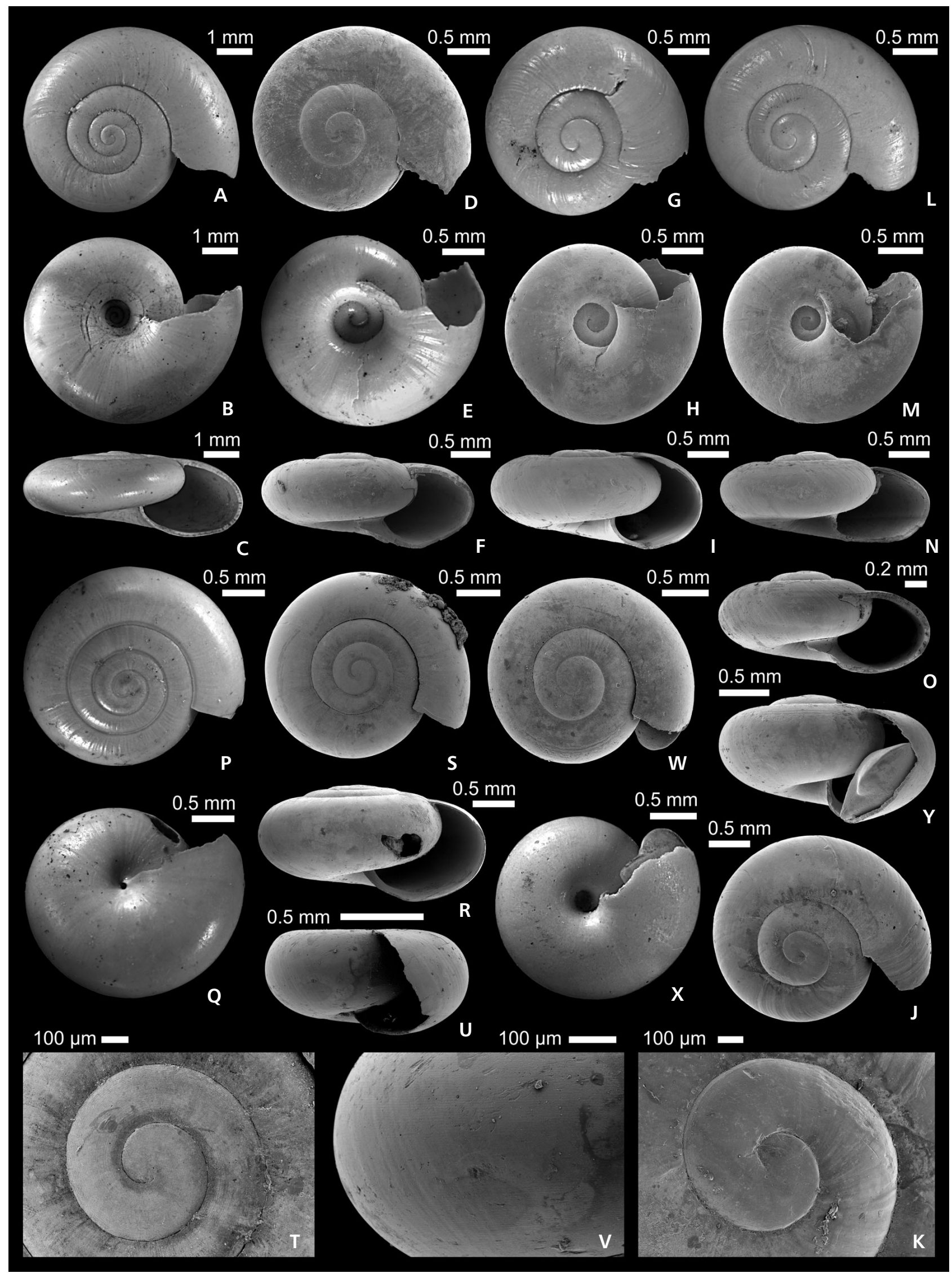


Republic), has a narrower coiling, is slightly larger and develops a stronger growth lines. Aegopinella vetusta (Klika, 1891), from the same locality, has a flat spire, a regularly convex periphery and has a narrower last whorl. The early to late Miocene Aegopinella subnitens (Klein, 1853), A. erecta (Gottschick, 1920) and A. reussi (Hörnes, 1856) differ all in their higher spires (see Schlickum 1976, Lueger 1981, Harzhauser et al. 2011). Oxychilus procellaria (Jooss, 1918) is distinguished by its deep suture and narrow last whorl (see syntype in Salvador et al. 2016a).

Occurrence.- Only known from Nowa Wieś Królewska at Opole (Poland).

\section{Aegopinella sp.}

Figure $12 \mathrm{~L}-\mathrm{O}$

1902b Hyalinia (Polita) mendica Slavic. - Andreae, p. 8 (non Helix (Hyalina) mendica Slavík, 1869).

1903 [Hyalinia] (Polita) mendica Slav. - Andreae, p. 540 (non Slavík, 1869).

1904a Hyalinia (Polita) mendica Slav. - Andreae, p. 16 (non Slavík, 1869).

1904b Hyalinia (Polita) mendica (Slav.). - Andreae, p. 250 (non Slavík, 1869).

2016 Zonitoides mendicus. - Höltke et al., p. 235 (non Slavík, 1869).

Material. - 5 specimens (NHMW 2017/0092/0100).

Dimensions. - Diameter: $1.95 \mathrm{~mm}$, height: $0.9 \mathrm{~mm}$ (Fig. 12O); diameter: $2.4 \mathrm{~mm}$, height: $0.95 \mathrm{~mm}$ (Fig. 12L-N).

Description. - Small, discoidal shell of about 2.5 whorls; spire low, broadly obtuse conical. Protoconch smooth aside from weak spiral threads close to suture. Whorl tops moderately convex with distinct suture. Periphery convex with faint angulation slightly above mid-whorl. Base convex; umbilicus moderately wide, perspective. Shell surface glossy, with weak growth lines, weakly prosocyrt in apical view, sigmoidal-prosocline in lateral view and orthocline on base. Teleoconch whorls entirely covered by very delicate microsculpture of spiral threads.

Remarks. - Andreae (1902b) mentioned rare specimens of "Oxychilus" mendicus (Slavík, 1869), which was originally described from the Burdigalian of Tuchořice and revised by Harzhauser et al. (2014a). Despite some similarities in shape and microsculpture, that species differs in its tighter coiling, narrower aperture and slightly larger size. Harzhauser et al. (2014a) erroneously listed the species from Nowa Wieś Królewska as Perpolita wenzi Schlickum \& Strauch, 1975, which was described from the Aquitanian of Donaurieden (Germany). The present species can be dis- tinguished by the larger size of $P$. wenzi and its narrower umbilicus. The presence of spiral threads distinguishes this species clearly from Perpolita miocaenica. Its overall shell shape and umbilicus suggests a placement in Aegopinella rather than in Oxychilus Fitzinger, 1833.

Occurrence. - Nowa Wieś Królewska at Opole (Poland).

\section{Genus Perpolita Baker, 1928}

Type species. - Baker (1928) fixed Helix hammonis Strøm, 1765 as type species by original designation (Recent USA). However, he later (Baker 1930) considered the specimens on which he had based this name to be misidentified Helix electrina Gould, 1841. A type species has to be fixed under Art. 70.3 of the Code.

Note. - Perpolita is commonly regarded as synonym of Nesovitrea Cooke, 1921 (e.g. Welter-Schultes 2012, Neubauer 2016). Other authors, like Schileyko (2003) and de Winter et al. (2016), restrict Nesovitrea to the Hawaiian radiation. Preliminary molecular data of de Winter et al. (2016) support this separation of the North American and Palearctic species.

Perpolita miocaenica (Andreae, 1902) comb. nov. Figure 12D-K

*1902b Hyalinia (Polita) miocaenica n. sp.; Andreae, p. 8, text-fig. 2.

1903 [Hyalinia (Polita)] miocaenica n. sp. - Andreae, p. 540.

1904a Hyalinia (Polita) miocaenica m. - Andreae, p. 16.

1904b Hyalinia (Polita) miocaenica m. - Andreae, p. 250.

? 1910 Hyalinia (Polita) miocaenica Andreae.-Gaál, p. 46, pl. 3, fig. 15 .

1923 Zonitoides (Zonitoides) miocaenicus (Andreae). Wenz, p. 297.

? 1925 Hyalinia (Polita) miocaenica Andr. - Rotarides, p. 137.

Material. - 137 specimens (NHMW 2017/0092/0099).

Dimensions. - Diameter: $2.7 \mathrm{~mm}$, height $1.1 \mathrm{~mm}$ (Fig. 12D-F).

Description. - Small discoidal shell with nearly flat spire. Protoconch nearly flat comprising 1.25 weakly convex whorls with incised suture; microsculpture consisting of few indistinct spiral grooves along upper and lower suture, fading out already within early parts of protoconch. Transition into teleoconch very indistinct; preserved teleoconch consisting of less than two whorls; last whorl distinctly widening; whorl tops only weakly convex, smooth aside 
from few slightly prosocyrt growth lines. Periphery regularly convex; growth lines prosocline sigmoidal in lateral view. Base moderately convex, smooth aside from orthocline growth lines. Umbilicus moderately wide, perspective. Peristome thin; inner lip slightly widening towards parietal region.

Remarks. - This small species is characterized by its rather wide last whorl, which covers comparatively large parts of the penultimate whorl. The glossy teleoconch lacks any spiral sculpture, which suggests a placement in Perpolita.

Perpolita disciformis Lueger, 1981, from the late Miocene of the Vienna Basin, resembles this species in terms of shape and the identical microsculpture on the protoconch, but it differs in its larger size (see Harzhauser \& Binder 2004). Perpolita boettgeriana (Clessin, 1877), from the early/middle Miocene of Undorf (Germany), is highly reminiscent of $P$. miocaenica. Judging from the illustrations of P. boettgeriana in Schlickum \& Strauch (1975) and Salvador et al. (2016a) separation is based on its more prominent radial sculpture, higher last whorl and slightly narrower umbilicus.

Occurrence. - Nowa Wieś Królewska at Opole (Poland).

\section{Genus Daudebardia Hartmann, 1821}

Type species. - Helix rufa Draparnaud, 1805; by subsequent designation by Herrmannsen (1846). Recent, Europe.

\section{Daudebardia praecursor Andreae, 1902}

Figure 13A-G

*1902a Daudebardia praecursor nov. sp.; Andreae, p. 3, text-fig. 1.

1902b Daudebardia praecursor m. - Andreae, p. 6.

1903 Daudebardia praecursor n. sp. - Andreae, p. 539.

1904a Daudebardia praecursor m. - Andreae, p. 16.

1904b Daudebardia praecursor m. - Andreae, p. 250.

1923 Daudebardia (Daudebardia) praecursor Andreae. Wenz, p. 307.

non 1954 Daudebardia cf. praecursor Andreae. - Papp \& Thenius, p. 21, pl. 4, fig. 12 (= Vitrinidae sp. indet.).

non 2006 Daudebardia praecursor Andreae, 1902. - Kókay, p. 78, pl. 30, figs 2,3 .

2016 Daudebardia praecursor. - Höltke et al., p. 235.

non 2016 Daudebardia cf. praecursor Andreae, 1902. - Mitrović, p. 51, pl. 1 fig. 4 (= probably a Vitrinidae).

Material. - 128 specimens (NHMW 2017/0092/0073).

Dimensions. - Largest specimen: height: $0.8 \mathrm{~mm}$, length: $7.0 \mathrm{~mm}$ (Fig. 13A, B).
Description. - Delicate, elongate oval shell comprising greatly inflated last whorl; protoconch consisting of about 1 low, smooth, nearly flat whorl of about $1 \mathrm{~mm}$ diameter, with densely spaced, flat spiral cords separated by very narrow grooves; transition into teleoconch indicated by onset of growth lines. Where last whorl starts to widen considerably, spiral cords become irregular, wavy, partly interrupted; spirals cords fade out towards aperture. Spiral sculpture persists on strongly convex base. Peristome on upper shell side strongly convex, thin; moderately concave on lower side, with slightly thickened inner lip, being weakly reflected at narrow umbilicus.

Remarks. - This genus has been rarely reported from Miocene deposits. Aside from the Polish occurrence, a second species occurs in the Sarmatian of Varpalota (Hungary), which was misidentified as Daudebardia praecursor by Kókay (2006). The Hungarian form differs clearly in its wide umbilicus. Similarly, the specimen from the early Miocene of Serbia described by Mitrović (2016) as D. cf. praecursor has a very wide umbilicus. Two additional Neogene species were described by Steklov (1966) from Azerbaijan: D. praelederi Steklov, 1966, from the Maeotian of Nizhnii Bumut at the Fortanga river, and D. fragilis Steklov, 1966 from the Sarmatian of Eljhotono at the Terek river. Both differ from D. praecursor in their wider umbilicus.

Occurrence. - Middle Miocene of Nowa Wieś Królewska at Opole (Poland).

Family Pristilomatidae Cockerell, 1891

\section{Genus Eurocystina gen. nov.}

Type species. - Eurocystina nordsiecki sp. nov.

Etymology. - A combination of Europe and - cystina, referring to the resemblance with Ariophantidae genus Microcystina Mörch, 1872.

Diagnosis. - Tiny, stout lentiform shell of about 3.5 whorls with low spire; protoconch bearing spiral rows of tiny pits; teleoconch entirely covered by delicate, densely spaced, slightly wavy spiral grooves. Umbilicus punctiform; columella forming minute triangular spur close to umbilicus.

Remarks. - Overall shell shape as well as the umbilical spur remind of the genus Vitrea Fitzinger, 1833. Accordingly, we place the new genus in Pristilomatidae. A clear difference to Vitrea is the presence of spiral rows of tiny pits on the protoconch, where Vitrea typically bears spiral grooves (e.g. Neubauer et al. 2017). The new genus is also somewhat reminiscent of the extant Microcystina Mörch, 
1872, which is distributed in Asia and eastern Africa. Near identical protoconch and teleoconch sculptures are present in extant Microcystina species, such as M. minima (H. Adams, 1867) and M. rowsoni Gittenberger \& van Bruggen, 2013 from Pemba Island (see Gittenberger \& van Bruggen 2013) and M. muscorum Van Benthem Jutting, 1959 from Borneo (see Vermeulen et al. 2015). An additional feature typical for many Microcystina species is the presence of a minute, triangular spur protruding from the columellar corner of the peristome, covering the umbilicus partly or entirely (Vermeulen et al. 2015). Despite these similarities, which are best explained as convergence, Eurocystina nordsiecki is smaller than typical Microcystina species, which range between 1.5 to $3.6 \mathrm{~mm}$ in diameter (Gittenberger \& van Bruggen 2013, Vermeulen et al. 2015). Moreover, a closer relationship with Microcystina is biogeographically very unlikely.

Other species. - Type species only.

Occurrence. - The new genus is only known from the middle Miocene of Central Europe.

\section{Eurocystina nordsiecki sp. nov.} Figure 10T-Aa

Holotype. - NHMW 2017/0092/0066: diameter: $1.25 \mathrm{~mm}$, height: $0.7 \mathrm{~mm}$ (Fig. 10Z-Aa).

Paratypes. - NHMW 2017/0092/0067, diameter: $1.25 \mathrm{~mm}$, height: $0.72 \mathrm{~mm}$ (Fig. 10X, Y); NHMW 2017/0092/0068: diameter: $1.2 \mathrm{~mm}$, height: $0.7 \mathrm{~mm}$ (Fig. 10T, U); NHMW 2017/0092/0069: diameter: $1.35 \mathrm{~mm}$. height: $0.8 \mathrm{~mm}$ (Fig. 10V, W).

Type horizon and locality. - Grey clayey marl ("Landschneckenmergel"), middle Miocene, late Langhian/early Serravallian (MN 6). Nowa Wieś Królewska at Opole (Poland).

Material. - 9 specimens (NHMW 2017/0092/0070).

Etymology. - In honor of Hartmut Nordsieck (Senckenberg Research Institute and Natural History Museum, Frankfurt), grand seigneur of European terrestrial malacology.

Diagnosis. - As for genus above.

Description. - Tiny, stout lenticular shell; spire slightly elevated. Protoconch comprising 1.5 weakly convex, almost flat whorls of $300 \mu \mathrm{m}$ diameter. Sculpture consisting of about 18 spiral rows of densely spaced, spaerical to subquadratic pits. Transition into teleoconch indicated by change of sculpture from spiral rows of well-separated pits into slightly wavy spiral grooves formed by nearly continuous pits. Spiral grooves separate narrow spiral bands on entire shell including base, being most prominent close to upper suture. Spire whorl tops moderately convex; periphery strongly and regularly convex; maximum diameter in mid-whorl. Aperture broadly crescent-moon-shaped, moderately wide, slightly sloping downwards in apertural view. Radial sculpture consists of irregularly spaced, weak, orthocline to slightly prosocline growth lines; sometimes blunt riblets occur locally. Peristome thin; basal lip and inner lip slightly widening. Umbilicus punctiform, partly covered by minute triangular spur protruding from columella; umbilical area concave.

Remarks. - As for the genus.

Occurrence. - Only known from Nowa Wieś Królewska at Opole (Poland).

\section{Genus Vitrea Fitzinger, 1833}

Type species. - Glischrus (Helix) diaphana Studer, 1820; by monotypy. Recent, Europe.

\section{Vitrea angustaeumbilicata sp. nov.} Figure 12P-V

Holotype. - NHMW 2017/0092/0074: diameter: $2.8 \mathrm{~mm}$, height: $1.35 \mathrm{~mm}$ (Fig. 12P-R).

Paratypes. - NHMW 2017/0092/0075: diameter: 2.4 mm, height: $1.2 \mathrm{~mm}$ (Fig. 12S, T); NHMW 2017/0092/0076: juvenile species (note that the spire is slightly pressed into the last whorl); diameter: $1.2 \mathrm{~mm}$, height: $0.6 \mathrm{~mm}$ (Fig. 12U, V).

Type horizon and locality. - Grey clayey marl ("Landschneckenmergel"), middle Miocene, late Langhian/early Serravallian (MN 6). Nowa Wieś Królewska at Opole (Poland).

Material. - 5 specimens (NHMW 2017/0092/0077).

Etymology. - From Latin angustus (= narrow); referring to the punctiform umbilicus.

Diagnosis. - Small discoid-lenticular shell with low spire, narrowly incised suture, weakly convex whorls and convex periphery and base; umbilicus punctiform. Protoconch with delicate spiral cords; teleoconch covered by very faint, shallow spiral grooves.

Description. - Small, glossy, discoid-lenticular shell of 3.5 whorls; spire almost flat. Protoconch comprising 1.5 nearly 
flat whorls; initial part and first 0.5 whorls smooth; later delicate spiral grooves separate flat spiral cords, being most prominent along upper and lower suture. Transition into teleoconch indicated by a reduction of spiral sculpture. Spire whorls nearly flat, separated by narrowly incised suture. Last whorl slightly widening, rather high; periphery regularly convex passing into convex base. Growth lines form delicate radial swellings on spire whorls but are inconspicuous along periphery (weakly prosocline) and base (orthocline). Teleoconch whorls entirely covered by very delicate, shallow spiral grooves, being even indistinct in SEM pictures and nearly invisible in light microscope. Umbilicus punctiform but open. Aperture halfmoon-shaped, moderately wide; peristome thin forming narrow inner lip in upper part of columella with narrow incision close to umbilicus.

Remarks. - This species is easily recognized by its punctiform umbilicus and nearly flat spire, differing clearly from the coeval Vitrea steinheimensis Gottschick, 1920 and co-occurring Vitrea procrystallina (Andreae, 1902). Vitrea subrimatula Wenz, 1921, from the late Miocene of Leobersdorf (Austria), is reminiscent of the Polish species in its narrow umbilicus but differs in its smaller size, the slightly gradate spire and the more convex spire whorls (see Wenz 1921, Lueger 1981). The late Oligocene Vitrea subdiaphana (Clessin, 1885) has much more elevated spire (see holotype in Salvador et al. 2016a). Vitrea faustinae (Sacco, 1884), from the Pliocene of Fossano (Italy), is tightly coiled and has a low conical spire unlike Vitrea angustaeumbilicata. Recent V. subrimata (Reinhardt, 1871) has a slightly wider shell, a narrower aperture and a slightly wider umbilicus.

It differs from the co-occurring Eurocystina nordsiecki nov. sp. in its larger size, nearly flat spire, wider last whorl and the absence of spiral rows of pits on the protoconch.

Occurrence. - Only known from the middle Miocene of Nowa Wieś Królewska at Opole (Poland).

\section{Vitrea procrystallina (Andreae, 1902)}

Figure 12W-Y

*1902b Hyalinia (Vitrea) procrystallina n. sp.; Andreae, p. 10 , text-fig. 4.

1903 [Hyalinia] (Vitrea) procrystallina n. sp. - Andreae, 540.

1904a Hyalinia (Vitrea) procrystallina m. - Andreae, 16.

1904b Hyalinia (Vitrea) procrystallina m. - Andreae, 250.

1923 Vitrea procrystallina procrystallina (Andreae). Wenz, p. 293.

2016 Vitrea procrystallina. - Höltke et al., p. 235.

2017 Vitrea procrystallina (Andreae, 1902). - Neubauer et al., p. 758, fig. 11c, f, 1 (cum syn.).
Material. - 16 specimens (NHMW 2017/0092/0078).

Dimensions. - Diameter: $2.3 \mathrm{~mm}$, height: $1.35 \mathrm{~mm}$ (Fig. 12W-Y); diameter: $2.8 \mathrm{~mm}$, height: $1.5 \mathrm{~mm}$.

Remarks. - This species was discussed in detail in Neubauer et al. (2017), who also provide discussion on its relationship with morphologically similar Miocene species.

Occurrence. - Originally described from the middle Miocene of Nowa Wieś Królewska at Opole (Poland); further occurrences from the early/middle Miocene of Andelfinger Berg near Riedlingen and Zwiefaltendorf in southern Germany and Ruggburg in western Austria (Gottschick 1920, Wenz 1935, Schlickum 1976); Sarmatian of Vračević (Serbia) and Zwierzyniec (Poland) (Stworzewicz et al. 2013, Neubauer et al. 2017) and several middle to late Miocene localities of Ukraine and Moldova (Gozhik \& Prysjazhnjuk 1978; Prysyazhniuk 2014, 2015b); late Miocene of the Vienna Basin (as V. steinheimensis; Lueger 1981, Harzhauser \& Binder 2004).

Family Vitrinidae Fitzinger, 1833

\section{Genus Phenacolimax Stabile, 1859}

Type species. - Helicolimax major A. Férussac in J. Férussac \& A. Férussac, 1807; by subsequent designation by P. Fischer in Paulucci (1878). Recent, Europe.

\section{Phenacolimax intermedius (Reuss in Reuss \& Meyer, 1849)}

Figure $13 \mathrm{H}-\mathrm{N}$

*1849 V.[itrina] intermedia m.; Reuss in Reuss \& Meyer, p. 18 , pl. 1, fig. 4 .

1902b Vitrina (Semilimax) intermedia Rss. - Andreae, p. 7.

1904a Vitrina (Semilimax) intermedia Rss. - Andreae, p. 16.

1904b Vitrina (Semilimax) intermedia Rss. - Andreae, p. 250.

2014a Phenacolimax intermedius (Reuss in Reuss \& Meyer, 1849). - Harzhauser et al., p. 883, fig. $14 \mathrm{v}-\mathrm{y}$ (cum syn.).

2016 Vitrina intermedia. - Höltke et al., p. 235.

Material. - 126 specimens (NHMW 2017/0092/0085).

Dimensions. - Largest specimen: length: $4.9 \mathrm{~mm}$, width: $3.5 \mathrm{~mm}$ (Fig. $13 \mathrm{~J}, \mathrm{~K})$.

Description. - Low shell with rapidly widening last whorl; protoconch comprising about 0.7 weakly convex whorls of 
$650 \mu \mathrm{m}$ diameter with indistinct suture. Initial cap bears few, irregularly spaced pits; remaining protoconch is covered by densely spaced, vaguely spirally arranged, subcircular tiny pits. Microsculpture weakens into smaller, more irregularly arranged pits towards transition into teleoconch and slightly beyond that (Fig. 13M); transition is marked by onset of growth lines. Teleoconch comprising c. 1.25 weakly convex whorls with slight subsutural concavity; periphery strongly convex, rapidly contracting into convex base; initial teleoconch whorl regularly widening up to about 0.75 whorls; afterwards rapidly widening and elongate. Shell surface bears faint prosocyrt growth lines and indistinct radial wrinkles along upper suture along protoconch. Base with distinct, orthocyrt growth lines parallel to deeply excavated peristome. Columella slightly twisted; very narrow inner lip, partly reflected over punctiform umbilicus.

Remarks. - Andreae (1902b) identified the shells from Nowa Wieś Królewska at Opole with Phenacolimax intermedius (Reuss in Reuss \& Meyer, 1849), yet without illustration. This species was originally described from the Burdigalian of Tuchořice and recently reviewed by Harzhauser et al. (2014a). A comparison of both occurrences confirmed the identification of Andreae (1902b). Phenacolimax suevica (Sandberger, 1875), from the late early and middle Miocene of S Germany and Poland, differs clearly in its less expanding last whorl (see Stworzewicz et al. 2013, Salvador et al. 2015).

Occurrence. - Known from the Burdigalian of Korozluky, Tuchořice and Pyšná (Czech Republic) and Theobaldshof/Rhön (Germany) and from the middle Miocene of Nowa Wieś Królewska at Opole (Moayedpour 1977, Harzhauser et al. 2014a).

\section{Phenacolimax crassitesta (Andreae, 1902)}

*1902b Vitrina (Semilimax) intermedia Rss. var. crassitesta n. nom (Klika.); Andreae, p. 7.

1903 [Vitrina (Semilimax) intermedia Rss.] var. crassitesta n. n. Klika. - Andreae, p. 540.

1904a [Vitrina (Semilimax) intermedia Rss.] var. crassitesta (Klika). - Andreae, p. 16.

2014a Phenacolimax crassitesta (Andreae, 1902). - Harzhauser et al., p. 883 (cum syn.).

Material. - No material available.
Remarks. - Andreae (1902b) based this species on 3 specimens, which differ from the frequent $P$. intermedius (Reuss in Reuss \& Meyer, 1849) only by their thicker shells. The status of this species is doubtful.

Occurrence. - Originally described from the middle Miocene of Nowa Wieś Królewska at Opole (Poland); the occurrence in the Burdigalian of Tuchořice mentioned by Klika (1891) could not be confirmed by Harzhauser et al. (2014a).

Family Zonitidae Mörch, 1864

Subfamily Archaeozonitinae Pfeffer, 1930

\section{Genus Archaeozonites Sandberger, 1872}

Type species. - Helix (Zonites) subverticillus Sandberger, 1858; by subsequent designation by Jooss (1911b). Early Miocene; Germany.

\section{Archaeozonites conicus Andreae, 1902}

Figure 13O-V

1902a Archaeozonites subangulosus (Benz.). - Andreae, p. 4 (non Helix subangulosa von Zieten, 1832).

*1902a Archaeozonites subangulosus (Benz.) var. conica $\mathrm{n}$. v.; Andreae, p. 4, text-fig. 2.

1902b Archaeozonites subangulosus (Benz.). - Andreae, p. 7 (non von Zieten, 1832).

1902b Archaeozonites conicus n. sp. - Andreae, p. 7.

1903 [Archaeozonites subangulosus Benz.] conicus n. sp. - Andreae, p. 540.

1904 Archaeozonites subangulosus Benz. - Michael, p. 380.

1904a Archaeozonites subangulosus (Benz.). - Andreae, p. 16 (non von Zieten, 1832).

1904a Archaeozonites conicus m. - Andreae, p. 16.

1904b Archaeozonites subangulosus (Benz.). - Andreae, p. 250 (non von Zieten, 1832).

1904b Archaeozonites conicus m. - Andreae, p. 250.

1908 Archaeozonites subangulosus. - Wegner, p. 112 (non von Zieten, 1832).

1923 Zonites (Aegopis) conicus (Andreae). - Wenz, p. 253.

1930 Omphalosagda conica (Andreae). - Pfeffer, p. 25, pl. 1, figs 19, 20, 31 .

2014 A.[rchaeozonites] conicus Andreae. - Nordsieck, p. 165.

Figure 13. Oxychilidae, Vitrinidae and Zonitidae. - A-B, C, D-E, F, G - Daudebardia praecursor Andreae, 1902 (NHMW 2017/0092/0073). - H-I, J-K, L-M, N - Phenacolimax intermedius (Reuss in Reuss \& Meyer, 1849) (NHMW 2017/0092/0085). O-R, S-V - Archaeozonites conicus Andreae, 1902 (NHMW 2017/0092/0096). 
Mathias Harzhauser \& Thomas A. Neubauer • Opole (Poland) - a key locality for middle Miocene terrestrial mollusc faunas

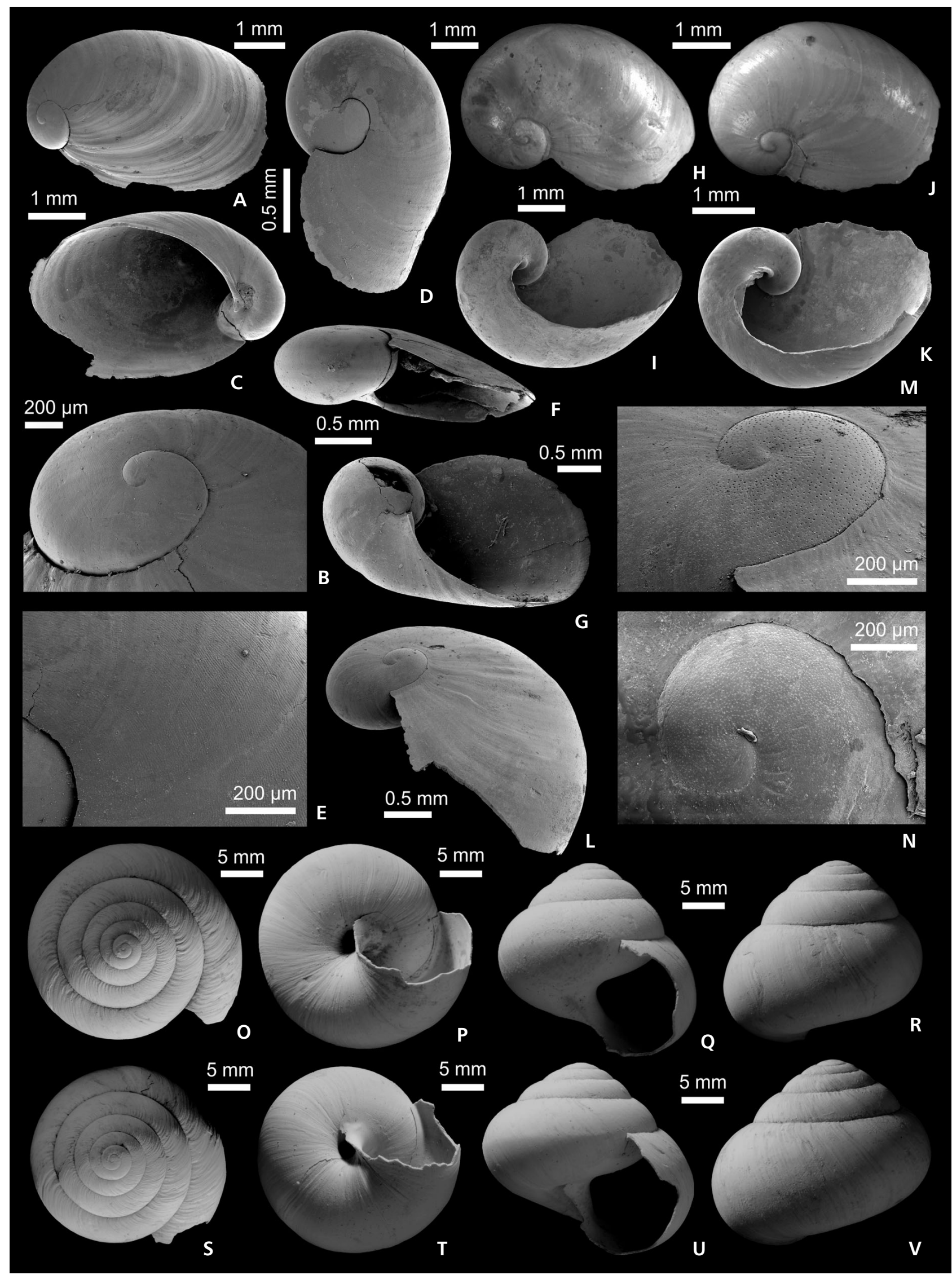


2016 Archaeozonites conicus. - Höltke et al., p. 235.

Material. - 247 specimens (NHMW 2017/0092/0096).

Dimensions. - Largest specimen: diameter: $27.4 \mathrm{~mm}$, height: $24.3 \mathrm{~mm}$.

Description. - Thin-shelled, glossy, rather high conical shell of five moderately convex whorls and incised suture. Early spire obtuse; protoconch nearly flat with incised suture; surface bears extremely delicate spiral wrinkles close to lower suture. Transition into teleoconch indistinct, indicated by gradual onset of sigmoidal axial riblets, being most prominent at upper suture; diameter of shell at onset of grooves $1.7 \mathrm{~mm}$. Soon, riblets grade into regularly spaced, weakly prosocyrt axial ribs with convex tops. Axial ribs become densely spaced, somewhat irregular and rarely bifurcating, ranging around 140 on second teleoconch whorl. Ribs become less prominent and prosocline on later teleoconch whorls. Last whorl regularly convex with faint mid-whorl angulation; base strongly convex; peristome thin, only inner lip slightly expanded and weakly reflected. Umbilicus narrow, perspective. Low, thickened swelling appears inside shell, at some distance behind peristome, without counterpart on shell surface, probably representing growth interruptions.

Remarks. - The rich material shows two morphotypes as end members with more or less high conical outlines (Fig. 13O-R versus 13S-V). This variability is typical for Archaeozonitidae (Wenz 1916) and therefore we unite both morphotypes in Archaeozonites conicus as already proposed by Wenz (1923). This species was placed in the Oligocene to early Miocene Omphalosagda Sandberger, 1875 by Pfeffer (1930), mainly based on the globular outline and the internal axial swellings. Nordsieck (2014) doubted this placement based on the "Archaeozonitestype" protoconch. This feature is confirmed herein by SEM pictures. Thus, we tentatively follow Nordsieck (2014), although we have not studied the protoconch of the genotype Omphalosagda goldfussii (Thomä, 1845).

Occurrence. - Only known from Nowa Wieś Królewska at Opole (Poland).

Superfamily Helicoidea Rafinesque, 1815

Family Elonidae Gittenberger, 1979

Subfamily Klikiinae H. Nordsieck, 1986

\section{Genus Klikia Pilsbry, 1895}

Type species. - Helix osculum Thomä, 1845; by original designation. Miocene, Germany.

\section{Klikia sp.}

1902b Helicodonta (Klikia) cf. osculum (Thom.). - Andreae, p. 11.

1903 Helicodonta (Klikia) cf. osculum Thom. - Andreae, p. 541.

1904a Helicodonta (Klikia) cf. osculum (Thom.). - Andreae, p. 17.

1904b Helicodonta (Klikia) cf. osculum (Thom.). - Andreae, p. 251.

Material. - No material available.

Remarks. - Andreae (1902b) mentioned only fragments, which he tentatively identified as Klikia osculum (Thomä, 1845), referring to specimens from Hochheim (Germany) and Tuchořice (Czech Republic). The Czech occurrence, however, represents Klikia labiata (Klika, 1891) (see Harzhauser et al. 2014a). Wenz (1923) lists the record from Nowa Wieś Królewska at Opole as Klikia giengensis (Klein, 1846), yet without any discussion. Thus, the identity of the Polish specimens remains unclear without additional material.

\section{Genus Apula C. Boettger, 1909}

Type species. - Helix devexa Reuss, 1861; by original designation. Early Miocene, Czech Republic.

\section{Apula sp.}

1904a Hygromia (Monacha) cf. devexa (Reuss). - Andreae, p. 10.

1904b Hygromia (Monacha) cf. devexa (Reuss). - Andreae, p. 251.

2016 Klikia coarctata. - Höltke et al., p. 235.

Material. - No material available.

Remarks. - Andreae (1904a) mentioned fragments, which he compared with the early Miocene Apula devexa (Reuss, 1861) and the middle Miocene Apula coarctata (Klein, 1853). Although, Andreae (1904a) stated closer affinities

Figure 14. Elonidae, Hygromiidae, Helicidae, Helicodontidae and Sphaeriidae. - A-D - Agalactochilus silesiacus (Andreae, 1902 ) (SMNS 66110 Staatliches Museum für Naturkunde Stuttgart). • E, F-G - Pseudoxerotricha neudorfensis (Andreae, 1904) (NHMW 2017/0092/0095). - H-I - Helicigona cf. atava Wenz, 1927 (NHMW 2017/0092/0098). • J-K - Protodrepanostoma involutum scabiosum (Sandberger, 1875) (NHMW 2017/0092/0094). • L-N, O-Q, R - Pisidium sp. (NHMW 2017/0092/0097). 


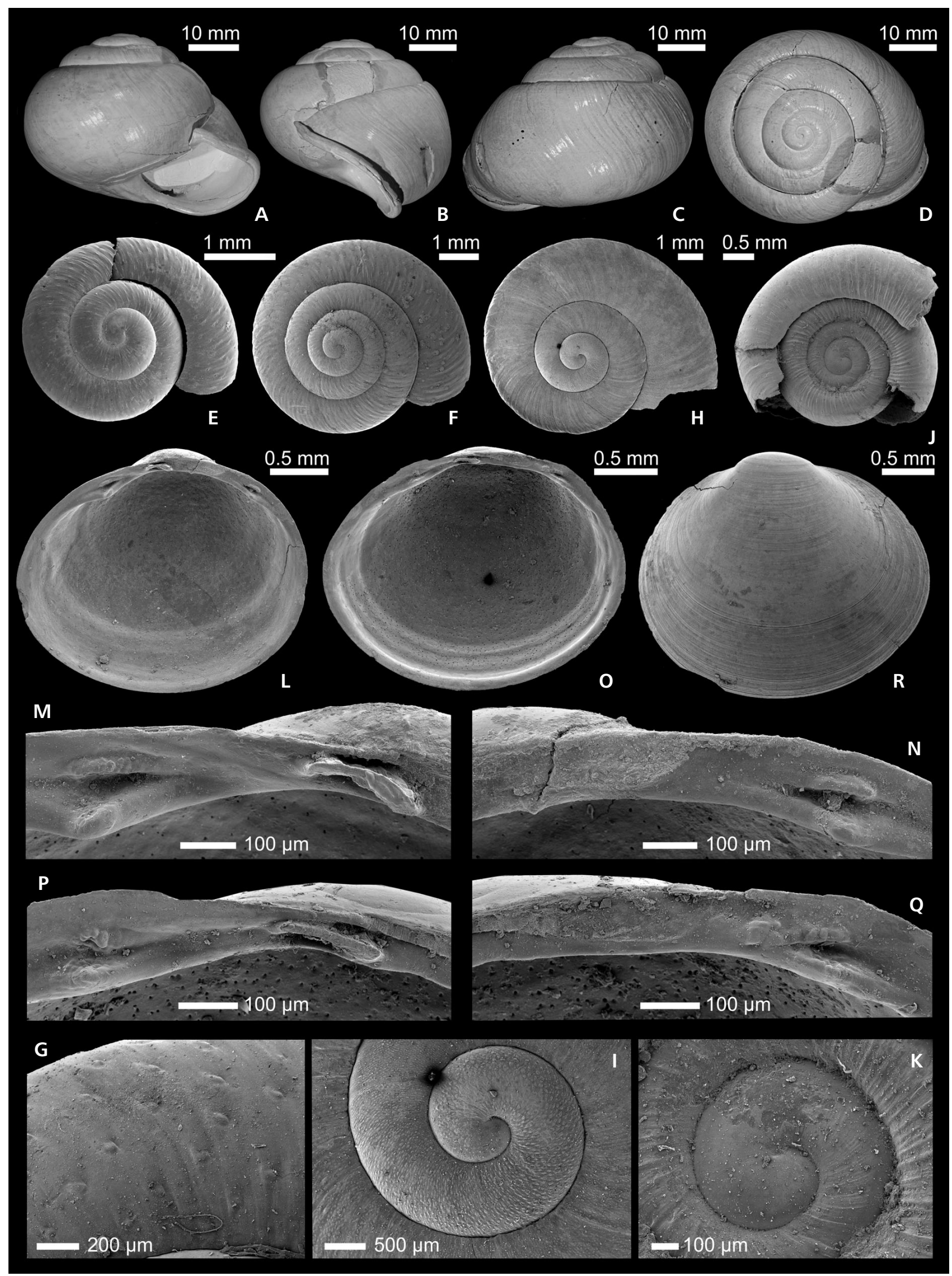


with A. devexa, Wenz (1923) listed the Polish occurrence under A. coarctata, which was followed by Höltke et al. (2016). Without additional material, the identity of the Polish specimens remains unclear.

Family Helicidae Rafinesque, 1815

Subfamily Ariantinae Mörch, 1864

\section{Genus Agalactochilus Kadolsky, Binder \& Neubauer, 2016}

Type species. - Helix leobersdorfensis Troll, 1907; by original designation. Late Miocene, Austria.

Note. - This genus is placed in Elonidae/Eloninae by Nordsieck (2017) whereas Kadolsky et al. (2016) discuss a placement in the Helicidae/Ariantinae.

\section{Agalactochilus silesiacus (Andreae, 1902)}

Figure 14A-D

*1902a Helix (Galactochilus) silesiaca nov. sp.; Andreae, p. 4, text-figs 3, 4 .

1902 Helix [sp.]. - Michael, p. 12.

1902b Pleurodonte (Galactochilus) silesiacum m. - Andreae, pp. 3, 5, 9, 17.

1902b Pleurodonte (Galactochilus) ehingensis (v. Klein).Andreae, p. 14 (non Helix ehingensis Klein, 1846).

1903 Pleurodonte (Galactochilus) silesiaca n. sp. - Andreae, p. 541.

1903 [Pleurodonte] (Galactochilus) ehingensis v. Klein. Andreae, p. 541 (non Klein, 1846).

1904 [Helix (Galactochilus)] oppoliensis. - Michael, p. 380. [nomen nudum]

1904a Pleurodonte (Galactochilus) silesiacum m. - Andreae, p. 8, text-fig. 8 .

1904b Pleurodonte (Galactochilus) silesiacum m. - Andreae, p 251, text-fig. 1.

1904b Pleurodonte (Galactochilus) ehingensis (v. Klein). Andreae, p. 251 (non Klein, 1846).

1923 Galactochilus silesiacum (Andreae). - Wenz, p. 498.

2016 Galactochilus silesiacus. - Höltke et al., p. 235.

2016 Galactochilus brauni ehingense. - Höltke et al., p. 235 (non Klein, 1846).

2016 Agalactochilus silesiacus (Andreae 1902). - Kadolsky et al., p. 172, figs 21, 22 (cum syn.).

Material. - 1 specimen (NHMW 1972/1513/0010/1); 1 specimen (State Museum for Natural History Stuttgart, SMNS 66110); 12 fragments (NHMW 2017/0092/0088).

Dimensions. - Diameter: $34.3 \mathrm{~mm}$, height: $24.9 \mathrm{~mm}$ (Fig. 14A-D); diameter: $27.8 \mathrm{~mm}$, height: $20.3 \mathrm{~mm}$ (ju- venile); Andreae (1902a, b) indicate a maximum size of $55 \times 43 \mathrm{~mm}$.

Remarks. - This species and related species were recently revised by Kadolsky et al. (2016), who introduced Agalactochilus as a new genus for this European species group. See Kadolsky (2017) for discussion of Galactochilus s.s.

Occurrence. - Originally described from the middle Miocene of Nowa Wieś Królewska at Opole (Poland); additional occurrences are recorded from the Sarmatian of Ferlach (Austria) and Leše [= Liescha] (Slovenia) by Kadolsky et al. (2016).

\section{Genus Helicigona A. Férussac, 1821}

Type species. - Helix lapicida Linnaeus, 1758; by subsequent designation by Pilsbry (1895). Recent, Europe.

\section{Helicigona cf. atava Wenz, 1927}

Figure 14H, I

$$
\begin{aligned}
& \text { cf. *1927 Helicigona (Helicigona) atava n. sp.; Wenz, p. 46, } \\
& \text { pl. 2, figs 6a-c. } \\
& \text { cf. } 1981 \text { Helicigona atava Wenz. - Lueger, p. 65, pl. 9, } \\
& \text { figs 1a-c. }
\end{aligned}
$$

Material. - 1 spire fragment (NHMW 2017/0092/0098).

Dimensions. - Diameter: $8.5 \mathrm{~mm}$.

Description. - A single spire fragment of 2.7 whorls is available; spire nearly flat. Protoconch consisting of about 1.3 weakly convex whorls; transition into teleoconch marked by onset of growth lines. Initial cap smooth; first protoconch whorl with large, densely spaced sub-rhombic beads, passing into smaller, regularly axially elongated beads towards teleoconch. Teleoconch entirely covered by very delicate tiny beads, resulting in a faintly granulose surface. Teleoconch whorls feebly convex passing into shallow concavity close to lower suture, separating weak, narrow bulge, which coincides with very narrow keel and with periphery of shell. Suture narrowly incised. Macrosculpture formed by prominent growth lines, being most prominent at adsutural bulge. Below keel, whorls contract extraordinarily rapidly, suggesting very low, discoidal shell outline. Base and aperture not preserved.

Remarks. - Despite the fragmentary preservation, the shell is very characteristic due to its nearly flat spire, prominent sculpture and extremely narrow keel. Wenz (1927) and Lueger (1981) described Helicigona atava from the late Miocene (Pannonian) of the Vienna Basin, which matches the Polish specimen in spire outline, sculpture and size. 
Unfortunately, the holotype is lost (Lueger 1981) and the second available specimen from Leobersdorf, described by Lueger, lacks protoconch and early spire. Therefore, comparison of the excellently preserved microsculpture of the early spire whorls of the specimen from Opole with the Viennese material is limited. Helicigona planata Binder, 2002, from the early Miocene (Karpatian) of the Korneuburg Basin in Austria, has also a nearly flat spire but differs in its larger size (17 mm diameter), more convex spire tops, the less pronounced keel and the wide spaced papillae. For a separation of $H$. atava from further Miocene Helicigona species, see Lueger (1981).

Occurrence. - Originally described from the late Miocene (Pannonian) of Leobersdorf (Austria); an additional but dubious occurrence was reported from the middle Miocene (Sarmatian) of Hollabrunn (Austria) (Lueger 1981). This species was not reported from Nowa Wieś Królewska at Opole (Poland) before.

Family Helicodontidae Kobelt, 1904

\section{Genus Protodrepanostoma Germain, 1929}

Type species. - Helix (Polygyra) plioauriculata Sacco, 1889; by original designation. Pliocene, Italy.

\section{Protodrepanostoma involutum scabiosum}

(Sandberger, 1875)

Figure 14J, K

1853 Helix involuta Thomae. - Klein, p. 211, pl. 5, fig. 8 (non Helix involuta Thomä, 1845 s. str.).

*1875 Helix scabiosa Sandb.; Sandberger, p. 377.

1902b Helicodonta cf. involuta (Thom.). - Andreae, p. 11.

1903 [Helicodonta] cf. involuta Thom. - Andreae, p. 541.

1904a Helicodonta (Helicodonta s. str.) involuta (Thom.). - Andreae, p. 11 (non Thomä, 1845 s. str.).

1904b Helicodonta (Helicodonta) involuta (Thom.). - Andreae, p. 251 (non Thomä, 1845 s. str.).

1923 Helicodonta (Helicodonta) involuta scabiosa (Sandberger). - Wenz, p. 452 (cum syn.).

2015 Helicodonta involuta (Thomae, 1845). - Salvador et al., p. 262, fig. 4h-j (non Thomä, 1845 s. str.).

Material. - 30 shell fragments (NHMW 2017/0092/0094).

Dimensions. - Largest fragment: diameter: $6.2 \mathrm{~mm}$, height: $2.9 \mathrm{~mm}$.

Remarks. - The status of Protodrepanostoma involutum (Thomä, 1845) and its various subspecies is still unresolved. Falkner (1986) tried to distinguish several species and subspecies based on quantitative differences in micro- sculpture, which was followed by Harzhauser et al. (2014a). Manganelli \& Giusti (2000) criticized Falkner's method but emphasized that a revision of the various nominal taxa is needed. Finally, Salvador et al. (2015) lumped all taxa again together in a single species without studying material. We did not compare type material and the available specimens from Nowa Wieś Królewska at Opole are too fragmentary to test the identification key of Falkner (1986). Moreover, the type specimen(s) of Helix scabiosa is lost (Salvador et al. 2016a). Herein, we follow Wenz (1923) and Falkner (1986) and treat the middle Miocene specimens as $P$. involutum scabiosum and consider it a chrono-subspecies of the Oligocene to early Miocene $P$. involutum. The generic status of this (sub)species-flock was clarified by Nordsieck (2014).

Occurrence. - Numerous late early and middle Miocene localities in S Germany, such as Undorf, Hohenmemmingen, Randeck, and Mörsingen (see Wenz 1923). Sarmatian of Rákosd (= Răcăștia) in Romania (Gaál 1910).

\section{Protodrepanostoma hecklei (Klika, 1891)}

*1891 [Helix (Trigonostoma Fitz.) involuta Thomae] var. hecklei; Klika, p. 47, text-figs 40a, b.

1904a [Helicodonta (Helicodonta s. str.) involuta (Thom.)] var. hecklei. - Andreae, p. 11.

2014a Protodrepanostoma hecklei (Klika, 1891). - Harzhauser et al., p. 888, fig. 16g-n (cum syn.).

Material. - No material available.

Remarks. - Andreae (1904a) mentions fragments of this species, which differ from Protodrepanostoma involutum s.1. in the much larger size, being thus reminiscent of Protodrepanostoma hecklei.

Occurrence. - Originally described from the Burdigalian of Tuchoriice (Czech Republic); the occurrence at Nowa Wieś Królewska at Opole (Poland) needs confirmation.

Family Hygromiidae Tryon, 1866

\section{Genus Pseudoxerotricha C. Boettger, 1911}

Type species. - Helix subconspurcata Sandberger, 1875; by typification of replaced name. Late Oligocene, Germany.

\section{Pseudoxerotricha neudorfensis}

(Andreae, 1904) comb. nov.

Figure $14 \mathrm{E}-\mathrm{G}$

*1904a Hygromia (Fruticicola) neudorfensis Andreae; Andreae, p. 10, text-fig. 11. 
1904b Hygromia (Monacha) neudorfensis Andreae. - Andreae, p. 251.

1923 Monacha (Monacha) neudorfensis Andreae. Wenz, p. 415.

1930 Zenobiella (Monachoides) [neudorfensis Andreae]. - Wenz, p. 3028.

?2008 Helicellinae indet. spec. - Binder, p. 201, pl. 5, figs $3 a, b$.

2016 Monacha neudorfensis. - Höltke et al., p. 235.

Material. - 2 fragmentary specimens (NHMW 2017/0092/00895).

Dimensions. - Largest fragment: diameter: $5.2 \mathrm{~mm}$ (Fig. 14F, G); Andreae (1904a) recorded a diameter of $11 \mathrm{~mm}$ and a height of $8.5 \mathrm{~mm}$.

Description. - Low trochiform shell of 6 convex whorls with deeply incised suture. Protoconch whorl convex; initial part smooth, later with axial folds; transition into teleoconch indistinct. Teleoconch whorls with weakly prosocyrt, poorly defined, somewhat irregular, rarely bifurcating, axial folds. Large, wide-spaced, prominent hair pits cover entire shell, being most prominent close to convex periphery. Hair pits simple, deep, with maximum length of about $80-100 \mu \mathrm{m}$, consisting of circular to elliptical beads surrounded by moderately deep concavity; distance between pits on third whorl ranging from $c$. 200-400 $\mu \mathrm{m}$. Base and aperture not preserved.

Remarks. - When introducing the new genus Pseudoxerotricha, C. Boettger (1911) cited the original diagnosis of Helix subconspurcata of Sandberger (1875, p. 388) and designated this species as type species. Sandberger's diagnosis emphasizes dense and irregularly bifurcating axial ribs with large intercalated hair pits and fits fully to the sculpture of the Polish species. Unfortunately, P. subconspurcata has never been illustrated and the type specimen seems to be lost (Wenz in K. Fischer \& Wenz 1914). The specimens mentioned by C. Boettger (1911) were later identified as Trichiopsis leptoloma [= Leucochroopsis leptoloma (Braun in Walchner, 1851)] by Wenz in K. Fischer \& Wenz (1914). Therefore, the status of this genus remains unclear and the placement of the Polish Miocene species in Pseudoxerotricha, which was known so far only from the Oligocene, may be debatable.

Pseudoxerotricha subconspurcata (Sandberger, 1875), the type species of this genus, was listed by Nordsieck (2017) as Geomitridae C. Boettger, 1909. The assumed moist paleohabitat of $P$. subconspurcata and $P$. neudorfensis, however, contradicts a relation with this xerophilic group. Therefore, as suggested by H. Nordsieck (personal communication July $22^{\text {nd }} 2017$ ), a placement within Hygromiidae is more appropriate. Only a limited number of hygromiid genera are known so far from the Miocene of Europe. In his overview, Nordsieck (2014) lists following genera: Helicopsis Fitzinger, 1833, Leucochroopsis (Leucochroopsis) O. Boettger, 1908, Leucochroopsis (Palaeotrichia) Nordsieck, 2014, Pseudomonacha Pfeffer, 1930 and Xerosecta Monterosato, 1892. None of these develop similarly prominent hair pits in combination with a macrosculpture of irregular axial folds. Similarly, Urticicola Lindholm, 1927 sensu Salvador (2013), from the early/middle Miocene of S Germany, differs in its dense and regular pattern of tiny papillae. The hair pits in extant Trochulus Chemnitz, 1786 are weaker and shallower (see Proćków 2009); the microsculpture of Monachoides and Perforatella species differs considerably by the presence of densely spaced, elongate "ship-hull" tubercles (see, e.g. Kerney et al. 1983, Pawlowska-Banasiak 2008); Fruticicola develops delicate spiral grooves, cut by coarser growth lines (Gargominy \& Ripken 2011).

Occurrence. - Only known from Nowa Wieś Królewska at Opole (Poland). A second occurrence might be represented by a specimen determined as Helicellinae indet. by Binder (2008) from the early Miocene of Oberdorf near Köflach (Austria).

Class Bivalvia Linnaeus, 1758

Subclass Heterodonta Neumayr, 1884

Superorder Imparidentia Bieler, Mikkelsen \& Giribet, 2014

Superfamily Sphaerioidea Deshayes, 1855 (1820)

Family Sphaeriidae Deshayes, 1855 (1820)

\section{Genus Pisidium C. Pfeiffer, 1821}

Type species. - Tellina amnica Müller, 1774; by subsequent designation by Gray (1947). Recent, Palearctic and E North America.

\section{Pisidium sp.}

Figure 14L-R

? 2006 Pisidium steinheimense Gottschick, 1920. - Kókay, p. 97, pl. 39, fig. 5 (non Pisidium steinheimense Gottschick, 1921).

? 2006 Pisidium ex. gr. conventus Clessin, 1877. - Kókay, p. 98, pl. 40, fig. 6 (partim; non Pisidium conventus Clessin, 1877).

Material. - 3 right valves (NHMW 2017/0092/0097).

Dimensions. $-2.35 \times 2.76 \times 0.82 \mathrm{~mm}$ (Fig. 14R); $1.91 \times$ $2.38 \times 0.65 \mathrm{~mm}$ (Fig. 14O-Q); $2.15 \times 2.57 \mathrm{~mm}$ (Fig. 14L-N). 
Description. - Shell almost perfectly elliptical, almost symmetrical, with little extending anterior portion. Umbo well rounded, not distinct, with smooth elliptical, flat, well-demarcated prodissoconch. Outer surface densely covered by growth lines; no marked rugae observed. Inner shell surface irregular, densely perforate. Both muscle scars distinct. Hinge plate narrow in both valves. Right valve: A1 short, broad, high, knobby, situated on broadly triangular hinge protrusion; A3 short, narrow, low, forming not more than irregular, strongly knobby surface in juveniles; C3 elongate, weakly curved in adults, almost straight in juveniles, passing from thin anterior into thickened posterior part; accompanied by ventral and dorsal depressions; ligament groove broad, almost reaching ventral hinge margin, length makes up about two thirds of distance between $\mathrm{C} 3$ and posterior teeth; P1 short, high, knobby, situated on minor hinge protrusion; P3 short, narrow, low, in juveniles not more than irregular, strongly knobby surface that is slightly shifted towards umbo.

Remarks. - Most middle Miocene Pisidium species can be distinguished from the present specimens by their distinctly triangular shells, i.e. P. amnicum (Müller, 1774) sensu Schneider \& Prieto (2011) from the Upper Freshwater Molasse of southern Germany; P. annandalei sensu Piechocki (1997) from Bełchatów; P. mionicense Neubauer, Harzhauser \& Mandic in Neubauer et al., 2017 from Vračević, Serbia; P. priscum (Eichwald, 1830) from Kuntscha [= Kuncha], Ukraine; $P$. pseudosphaerium Favre, 1927 sensu Kókay (2006) from Várpalota, Hungary. Pisidium bellardi Brusina, 1884, from the early middle Miocene of Miočić in Croatia, is more elongate, has a thinner hinge and a more obtuse umbo. Coeval Pisidium steinheimense Gottschick, 1921, from the Steinheim Basin, has an elongate-ovoid, more asymmetrical shell and has a more massive hinge. Pisidium steinheimense and Pisidium ex. gr. conventus sensu Kókay (2006) have very similar shell shapes. The poor figures and descriptions, however, do not allow clear conclusions on their identities. Pisidium personatum Malm sensu Kuiper (1972) and Harzhauser \& Binder (2004), from the Pannonian of the Vienna Basin, differs in its more spherical outline, smaller size and coarser perforation of the inner shell surface. As we have only three right valves at hand, we refrain from describing the Polish species formally as new species.

Occurrence. - Only known from Nowa Wieś Królewska at Opole (Poland).

\section{Discussion and Conclusions}

In total, 83 mollusc species are reported herein from the middle Miocene of Nowa Wieś Królewska at Opole representing 82 gastropods and one bivalve (Tab. 1). This number is a distinct increase in documented species compared to the 60 taxa listed by Andreae (1904a) and only 48 by Höltke et al. (2016). Ten species are formally described as new and several additional taxa might represent new species but are described in open nomenclature. This drastic increase in species numbers, based on a single bulk sample, suggests that the alpha-diversity of the locality is still not fully captured. Thus, in respect to its outstanding diversity, the fauna from Nowa Wieś Królewska at Opole is one of the key localities for Neogene terrestrial mollusc faunas of Europe, like Hochheim in Germany (late Oligocene) and Tuchořice in Czech Republic (early Miocene).

Already Andreae (1902b) tried to reconstruct biostratigraphic relations of the Opole fauna with other classical Oligocene and Miocene localities. At that time, a major obstacle for these comparisons was the partly inadequate documentation of the various faunas. Several revisions of important localities and taxonomic groups, including SEM pictures and descriptions of microsculptures, have become available up to now, which allow much more reliable comparisons. The restricted access to conchological information led to several misidentifications in the pioneer papers by Andreae (1902a, b, 1904a); e.g. the typical Oligocene "Pseudamnicola helicella" turned out to represent a completely unrelated, endemic hydrocenid species. Similarly, some assumed relations with Tuchořice are incorrect; e.g. the alleged occurrences of "Craspedopoma leptopomoides" and "Bythinella cyclothyra var. gracilis" revealed to be not conspecific with the species from Tuchorice. In other cases, the original identifications of "Tuchořice-species" by Andreae (1902b, 1904a) are confirmed herein (e.g. Esuinella nana, Spermodea plicatella).

Thus, based on the taxonomic composition and the semi-quantitative sampling method new biostratigraphic and paleoecologic conclusions can be outlined.

\section{Biostratigraphy}

Of the 83 mollusc species, six of the gastropods are identified only at genus or family level, as they were based on literature data from Andreae (1902a, b, 1904a, b) (Azecidae sp., Palaeomastus? sp., Oleacinidae sp., Klikia sp., Apula sp.) or might represent widespread but currently unidentifiable species (?Lymnaea sp.). These taxa are excluded from further calculations. The remaining 77 species are considered here as distinct species, even if they are partly described in open nomenclature (e.g. Craspedopoma sp., Pisidium sp.). Of these, 43 species (55.8\%) are only known so far from Nowa Wieś Królewska. The high number of seemingly endemic species not recorded from other localities might indicate that the fauna from Nowa Wieś Królewska derives 
Table 1. List of all taxa reported from Nowa Wieś Królewska; specimen numbers are based on the NHMW collection.

\begin{tabular}{|c|c|c|c|c|}
\hline nr. & Genus & Species & Author & specimens \\
\hline 1 & Hydrocena & trolli & Schlickum, 1979 & 254 \\
\hline 2 & Craspedopoma & sp. & & 20 \\
\hline 3 & Occidentina & martensi & (Andreae, 1902) & 88 \\
\hline 4 & Acicula & lineata & (Draparnaud, 1801) & 36 \\
\hline 5 & Acicula & isseli & (Flach, 1889) & 10 \\
\hline 6 & Platyla & callosiuscula & (Andreae, 1904) & 85 \\
\hline 7 & Platyla & falkneri & Boeters, Gittenberger \& Subai, 1989 & 12 \\
\hline 8 & Renea & pretiosa & (Andreae, 1904) & 6 \\
\hline 9 & Martinietta & kadolskyi & sp. nov. & 62 \\
\hline 10 & Pomatias & schrammeni & (Andreae, 1902) & 165 \\
\hline 11 & ?Lymnaea & sp. & & 5 \\
\hline 12 & Stagnicola & cf. palustriformis & (Gottschick, 1911) & 5 \\
\hline 13 & Aplexa & cf. subhypnorum & Gottschick, 1920 & 1 \\
\hline 14 & Anisus & guerichi & (Andreae, 1902) & 0 \\
\hline 15 & Ferrissia & deperdita & (Desmarest, 1814) & 1 \\
\hline 16 & Carychiopsis & surai & (Stworzewicz, 1999) & 13 \\
\hline 17 & Carychiella & eumicrum & (Bourguignat, 1857) & 8 \\
\hline 18 & Carychium & stworzewiczae & sp. nov. & 206 \\
\hline 19 & Carychium & nouleti & Bourguignat, 1857 & 152 \\
\hline 20 & Oxyloma & minima & (Klein, 1853) & 6 \\
\hline 21 & Acanthinula & trochulus & (Sandberger, 1872) & 7 \\
\hline 22 & Acanthinula & tuchoricensis & (Klika, 1891) & 7 \\
\hline 23 & Esuinella & nana & (Braun in Walchner, 1851) & 25 \\
\hline 24 & Spermodea & plicatella & (Reuss in Reuss \& Meyer, 1849) & 5 \\
\hline 25 & Argna & oppoliensis & (Andreae, 1902) & 3 \\
\hline 26 & Azeca & frechi & Andreae 1902 & 42 \\
\hline 27 & Azeca & sp. & & 9 \\
\hline 28 & Azecidae & gen. et sp. indet. & & 0 \\
\hline 29 & ?Palaeomastus & sp. & & 0 \\
\hline 30 & Gastrocopta (Albinula) & polonica & sp. nov. & 145 \\
\hline 31 & Gastrocopta (Sinalbinula) & ferdinandi & (Andreae, 1902) & 3 \\
\hline 32 & Leiostyla & piserai & sp. nov. & 4 \\
\hline 33 & Nordsieckula & falkneri & (Hausdorf, 1995) & 5 \\
\hline 34 & Pleurodiscoides (Pleurodiscoides) & mamillatus & (Andreae, 1904) & 1 \\
\hline 35 & Strobilops & costatus & (Clessin, 1877) & 106 \\
\hline 36 & Eostrobilops & boettgeri & (Andreae, 1902) & 171 \\
\hline 37 & Truncatellina & lentilii & (Miller, 1900) & 3 \\
\hline 38 & Vertigo & protracta & (Sandberger, 1875) & 2 \\
\hline 39 & Vertigo & trolli & Wenz in K. Fischer \& Wenz, 1914 & 125 \\
\hline 40 & Vertigo & antipygmaea & sp. nov. & 1 \\
\hline 41 & Negulopsis & lineolata & (Braun in Walchner, 1851) & 161 \\
\hline 42 & Negulopsis & raricosta & (Slavík, 1869) & 1 \\
\hline 43 & Triptychia & margaretae & Andreae, 1904 & 45 \\
\hline 44 & Serrulella & andreaei & Nordsieck, 1981 & 14 \\
\hline 45 & Serrulella & multiplicata & Nordsieck, 1981 & 8 \\
\hline 46 & Serrulastra (Serrulastra) & laevissima & Nordsieck, 1981 & 35 \\
\hline
\end{tabular}


Table 1 - continued

\begin{tabular}{|c|c|c|c|c|}
\hline nr. & Genus & Species & Author & specimens \\
\hline 47 & Serrulastra (Serruplica) & falkneri & Nordsieck, 1981 & 18 \\
\hline 48 & Constricta & $\mathrm{sp}$ & & 2 \\
\hline 49 & Regiclausilia & patula & Nordsieck, 1981 & 14 \\
\hline 50 & Cochlodina (Miophaedusa) & oppoliensis & Nordsieck, 1981 & 12 \\
\hline 51 & Pseudidyla (Canaliciella) & boettgeri & Nordsieck, 1981 & 45 \\
\hline 52 & Trolliella & silesiaca & Nordsieck, 1981 & 24 \\
\hline 53 & Pseudoleacina & fossilis & (Andreae, 1902) & 26 \\
\hline 54 & Pseudoleacina & rakosdensis & (Gaál, 1910) & 12 \\
\hline 55 & Oleacinidae & gen. et sp. indet. & & 0 \\
\hline 56 & Punctum & propygmaeum & Andreae, 1904 & 2 \\
\hline 57 & Helicodiscus & roemeri & (Andreae, 1902) & 5 \\
\hline 58 & Discus & solarioides & (Sandberger, 1872) & 5 \\
\hline 59 & Discus & $\mathrm{sp}$. & & 13 \\
\hline 60 & Mennoia & sculpturata & gen. et sp. nov. & 31 \\
\hline 61 & Neubertella & pulchra & gen. et sp. nov. & 7 \\
\hline 62 & Agriolimacidae & gen. et sp. indet. & & 38 \\
\hline 63 & Janulus & sp. & & 1 \\
\hline 64 & ?Lehmannia & excavata & (Andreae, 1904) & 23 \\
\hline 65 & Milax & oppoliensis & (Andreae, 1904) & 14 \\
\hline 66 & Aegopinella & depressula & sp. nov. & 1 \\
\hline 67 & Aegopinella & sp. & & 5 \\
\hline 68 & Perpolia & miocaenica & (Andreae, 1902) & 137 \\
\hline 69 & Daudebardia & praecursor & Andreae, 1902 & 128 \\
\hline 70 & Eurocystina & nordsiecki & gen. et sp. nov. & 13 \\
\hline 71 & Vitrea & angustaeumbilicata & sp. nov. & 8 \\
\hline 72 & Vitrea & procrystallina & (Andreae, 1902) & 16 \\
\hline 73 & Phenacolimax & intermedius & (Reuss in Reuss \& Meyer, 1849) & 126 \\
\hline 74 & Phenacolimax & crassitesta & (Andreae, 1902) & 0 \\
\hline 75 & Archaeozonites & conicus & Andreae, 1902 & 247 \\
\hline 76 & Klikia & sp. & & 0 \\
\hline 77 & Apula & sp. & & 0 \\
\hline 78 & Agalactochilus & silesiacus & (Andreae, 1902) & 12 \\
\hline 79 & Helicigona & cf. atava & Wenz, 1927 & 1 \\
\hline 80 & Protodrepanostoma & involutum scabiosum & (Sandberger, 1875) & 30 \\
\hline 81 & Protodrepanostoma & hecklei & (Klika, 1891) & 0 \\
\hline 82 & Pseudoxerotricha & neudorfensis & (Andreae, 1904) & 2 \\
\hline 83 & Pisidium & sp. & & 3 \\
\hline
\end{tabular}

from a taxonomically poorly resolved time-slice and/or biogeographic area of the continental Miocene. For example, it would be surprising to detect such high number of new taxa in the rather well documented circum-Paratethyan Sarmatian faunas (late middle Miocene; late Serravallian; MN 7+8), which have been described by Schütt (1967), Harzhauser et al. (2008), Stworzewicz et al. (2013) and Neubauer et al. (2017). The terrestrial mollusc faunas from the late early to early middle Miocene of S Germany (MN
5) have also been intensively studied during the last years (e.g. Finger 1998; Salvador et al. 2015, 2016a, b, c, 2017). Similarly, the late Miocene (Tortonian, Pannonian, MN 9) faunas from the hinterland of Lake Pannon are well documented by Schlickum (1978, 1979b), Lueger (1981) and Harzhauser \& Binder (2004). In contrast, revisions of early Miocene (Aquitanian-Burdigalian, Eggenburgian-Karpatian) and early middle Miocene (Badenian, Langhian) circum-Paratethyan faunas are comparatively much rarer 
(e.g. Binder 2002, 2004, 2008; Harzhauser et al. 2014a, b) and often based on small assemblages (e.g. Mandic \& Harzhauser 2003). Faunas corresponding in age to the mammal zone MN 6 are very rarely reported and best represented by that of Sansan in France. Unfortunately, a critical revision of this important mollusc fauna is still pending, as the contribution by J.C. Fischer (2000) provides only copies of the rather poor original illustrations of Dupuy (1850) and Bourguignat (1881).

From the 34 species that were also documented from other localities, ten species $(29.4 \%)$ are also known from the early Miocene (Burdigalian, MN 3b) of Tuchořice (Czech Republic), nine species (23.5\%) from the early/middle Miocene (MN 5) of Bełchatów B (Poland) and eight species $(23.5 \%)$ from the early/middle Miocene (MN 5) of Undorf (S Germany). This relation is contrasted by only five species (14.7\%) shared with the Sarmatian (MN 7+8) localities Zwierzyniec (Poland), Hollabrunn (Austria) and Vračević (Serbia). The same number of taxa is shared with the late Miocene locality Leobersdorf (Pannonian, MN 9). This pattern strongly indicates a maximum age corresponding to the mammal biozone MN 5, as no older occurrences are known so far for the easily recognizable genera Occidentina and Argna and the characteristic species Ferrissia deperdita, Strobilops costatus, Helicodiscus roemeri and Vitrea procrystallina. Other taxa, such as Martinietta, Carychiopsis and Esuinella are unknown so far from faunas younger than MN 5, which should not be overemphasized in respect to the poorly resolved MN 6 mollusc faunas. Their absence in the much better documented MN 7 mollusc faunas, however, seems to be more reliable. These tentative constraints leave a potential time window spanning the mammal zones MN 5-MN 6, representing the latest Burdigalian and the entire Langhian. Taking the prevailing dating of the mammal faunas from Opole into account, which strongly points to a correlation with the mammal biozone MN 6 (Głazek \& Szynkiewicz 1987, Kowalski 1990, Rzebik-Kowalska 2005, Mein 2009), narrows the time window to the late Langhian and middle Badenian, respectively. Interestingly, Nordsieck (1981a) arrived at the same conclusion based only on the evolutionary level of the clausiliid fauna and proposed a correlation with the mammal zone MN 6; later, Nordsieck (1982) widened the potential range to MN 6-MN 7. According to Nordsieck (1981a), the clausiliid fauna has closer evolutionary relations to those from the early Miocene of Tuchořice and the middle Miocene (mid-Badenian, Langhian) of Hrušovany (CZ) and is clearly older than that from the early Sarmatian of Hollabrunn.

Consequently, the fauna from Nowa Wieś Królewska is proposed here as type of a MN 6 mollusc fauna in Central Europe. This dating places the fauna from Nowa Wieś Królewska into the late phase of the Miocene Climate Op- timum close to a critical tipping-point of global climate, which resulted in the Middle Miocene Climate Transition (Zachos et al. 2001, Shevenell et al. 2004). In the Paratethyan basins, this climate deterioration is reflected by the Badenian Salinity Crisis (De Leeuw et al. 2010, Báldi et al. 2017) and a major drop of marine biodiversity (Harzhauser \& Piller 2007). The shift in climate might explain the absence of the enigmatic taxa Eurocystina and Neubertella in the younger Sarmatian faunas. The loss of Oligocene/early Miocene relics, such as Esuinella, might also be related to this major climate change.

\section{Paleoecology}

The total number of specimens studied herein ranges around 3090 individuals (Tab. 1). Despite the high species diversity, only few taxa predominate the assemblage. Only four species account for $25 \%$ of the total number of specimens: Hydrocena trolli, Archaeozonites conicus, Carychium stworzewiczae and Eostrobilops boettgeri. Carychiidae alone represent about $12 \%$ of the specimens. The ecological requirements of the extinct Archaeozonites are unknown, but all other taxa have recent relatives. Herein, information on the autecology of recent representatives of the recorded genera presently occurring in Europe derives mainly from Welter-Schultes (2012) if not indicated otherwise. The extant Hydrocena cattaroensis has a broad habitat range comprising littoral environments up to mountainous areas and cavities where it prefers rocks and humid habitats (Schlickum 1979a, Gittenberger \& Maassen 1980). Carychiidae inhabit permanently moist, superficial subterranean habitats in leaf litter and crevices, where they tend to form high population densities (Watson \& Verdcourt 1953, Morton 1954, Mason 1970). They are found in forests, meadows and riparian environments (Jochum et al. 2017). Extant Eostrobilops species are also found under stones and litter (Páll-Gergely et al. 2015). Other frequent taxa, accounting each between 4-5\% to the total number of specimens, are Pomatias schrammeni, Gastrocopta (Albinula) polonica, Daudebardia praecursor, Phenacolimax intermedius and Vertigo trolli. Extant Pomatias species are found in open woods, shrublands, rock rubble and maritime grasslands, partly preferring calcareous soil. Extant species of the carnivorous Daudebardia prefer humid and shady habitats under leaf litter and under stones in forests; it may occupy subterraneous habitats down to $25 \mathrm{~cm}$ depth (Rendoš et al. 2014). Moist leaf litter and rocks in humid forests, meadows and shrubland is also a typical habitat for extant Phenacolimax species. Gastrocopta species dwell in a great variety of habitats, ranging from xeric to wet settings, forested areas to shrublands and open grasslands and floodplains, in leaf litter, under logs or stones and on bedrock outcrops (Nekola \& Coles 2010). Similarly, Diplom- 
matinidae live in leaf litter on limestone rocks (Vermeulen 1997, Neubert \& Bouchet 2015). Vertigo species are often hygrophile, found in fens, swampy meadows and lake margins (Vavrová et al. 2009). Similar ecological requirements can also be stated for the less frequent taxa such as Acanthinula, Spermodea, Discus and others (see Neubauer et al. 2017).

Obligate freshwater species, in contrast, are rare and account for only $2.5 \%$ in specimen numbers. The aquatic assemblage consists only of pulmonate gastropods and a sphaeriid bivalve, indicative of lentic to slowing running, often highly vegetated water. The rare occurrence of freshwater species points to ephemeral ponds, swamps and fens with short settlement phases.

In summary, the majority of terrestrial gastropod species are indicative of a humid, forested environment with moist leaf litter, dead wood and calcareous soil. The latter is little surprising in respect to the underlying Cretaceous carbonate deposits, which were the source-rock for the Miocene marls (Andreae 1902a, Wegner 1908).

The species composition is unique for the European Neogene and about $56 \%$ are only known so far from Nowa Wieś Królewska. The remaining taxa show affinities to early and early middle Miocene faunas clearly indicating a pre-Sarmatian age and a potential time window corresponding to the MN 5 and MN 6 biozones of the European mammal biostratigraphy. Integrating the mammal data suggest a deposition during the MN 6 biozone, corresponding to the middle Badenian respectively late Langhian. As such, the assemblage from Nowa Wieś Królewska is the best-documented terrestrial mollusc fauna from the late Miocene Climate Optimum close to the global cooling of the middle Miocene Climate Transition.

\section{Acknowledgements}

We are grateful to Zoltán Fehér (Natural History Museum Vienna), Dietrich Kadolsky (Sanderstead, Surrey, U.K.), Giuseppe Manganelli (Università di Siena), Eike Neubert (Natural History Museum Bern), Menno Schilthuizen (Naturalis Biodiversity Center and Leiden University), Barna Páll-Gergely (Hungarian Academy of Sciences, Budapest) and Małgorzata Proćków (Museum of Natural History, Wrocław University) for many fruitful discussions and information. Our special thanks go to Hartmut Nordsieck (Senckenberg Research Institute and Natural History Museum, Frankfurt) for critical pre-review of this paper. Giuseppe Manganelli (Università degli Studi di Siena) and Ewa Stworzewicz (Polish Academy of Sciences, Warsaw) are thanked for constructive reviews. T.A.N. was supported by a Just'us postdoctoral fellowship granted by the University of Giessen, an Alexander-von-Humboldt Scholarship and a Martin Fellowship granted by Naturalis Biodiversity Center. This paper contributes to the FWF project P25365-B25 "Freshwater systems in the Neogene and Quaternary of Europe: Changes in gastropod biodiversity, provinciality, and faunal gradients".

\section{References}

Adams, H. 1866. Descriptions of six new species of shells, and note on Opisthostoma de-Crespignii. Proceedings of the Zoological Society of London 1866, 445-447.

ADAms, H. 1867. Descriptions of New Species of Shells collected by Geoffrey Nevill, Esq.; at Mauritius. Proceedings of the Scientific Meetings of the Zoological Society of London 35, 303-307.

Adams, H. \& Adams, A. 1853-1858. The genera of Recent Mollusca arranged according to their organization. 2 volumes of text (661 pp.), 1 vol. of plates. Van Voorst, London.

AlBERS, J.C. 1850. Die Heliceen, nach natürlicher Verwandtschaft systematisch geordnet. 262 pp. Enslin, Berlin. DOI 10.5962/bhl.title.10619

Albers, J.C. 1860. Die Heliceen nach natürlicher Verwandtschaft systematisch geordnet von Joh. Christian Albers. Zweite Ausgabe nach dem hinterlassenen Manuskript besorgt von Eduard von Martens. xviii +359 pp. Engelmann, Leipzig. DOI 10.5962/bhl.title.11218

ALDER, J. 1830. A catalogue of the land and fresh-water testaceous Mollusca found in the vicinity of Newcastle upon Tyne, with remarks. Transactions of the Natural History Society of Northumberland and Durham 1, 26-41.

Andreae, A. 1892. Anmerkung zu Ref. von: Penecke, Die Molluskenfauna des untermiocanen Susswasserkalkes von Reuen in Steiermark. Neues Jahrbuch für Mineralogie, Geologie und Paläontologie 1892, 436.

ANDREAE, A. 1902a. Untermiocäne Landschneckenmergel bei Oppeln in Schlesien. Mittheilungen aus dem Roemer-Museum, Hildesheim 16, 1-8.

ANDREAE, A. 1902b. Zweiter Beitrag zur Binnenconchylienfauna des Miocäns von Oppeln in Schlesien. Mittheilungen aus dem Roemer-Museum, Hildesheim 18, 1-31.

ANDREAE, A. 1903 [Untermiocäne Landschneckenmergel bei Oppeln in Schlesien]. Neues Jahrbuch für Mineralogie, Geognosie, Geologie und Petrefaktenkunde 1903(1), 538-542.

Andreae, A. 1904a. Dritter Beitrag zur Kenntnis des Miocäns von Oppeln i. Schl. Mittheilungen aus dem Roemer-Museum, Hildesheim 20, 1-22.

ANDREAE, A. 1904b. Kurzer Ueberblick über das Miocän von Oppeln i. Schles. und seine Fauna. Monatsberichte der deutschen geologischen Gesellschaft 56, 249-255.

BAKer, H.B. 1928. Minute American Zonitidae. Proceedings of the Academy of Natural Sciences of Philadelphia 80, 1-44.

BAKer, H.B. 1930. The North American Retinellae. Proceedings of the Academy of Natural Sciences of Philadelphia 82, 193-219.

BAKeR, H.B. 1938. Zonitid snails from Pacific islands. part I. 1. Southern genera of Microcystinae. Bernice P. Bishop Museum Bulletin 158, 1-102.

BÁldi, K., Velledits, F., Ćorić, S., Lemberkovics, V., LôRInCZ, K. \& Shevelev, M. 2017. Discovery of the Badenian evaporites inside the Carpathian arc: implications for global climate change and Paratethys salinity. Geologica Carpathica 68(3), 193-206. DOI 10.1515/geoca-2017-0015

BARTHA, F. 1956. A tabi pannóniai korú fauna. A Magyar Állami Földtani Intézet Èvkönyve 45(3), 481-595. 
BECK, H. 1837-1838. Index molluscorum praesentis aevi musei principis augustissimi Christiani Frederici. Fasciculus primus (1837): iv + 100 pp. fasciculus secundus (1838): 101-124 pp.; specierum novarum et characteres breves (1838): 8 pp; Hafniae.

BECK, H. 1847. Verzeichniss einer Sammlung von Landconchylien aus den Dänischen Staaten in Europa, bestehend aus 2,058 Individuen, darstellend 158 Arten, die $\mathrm{zu} 44$ Geschlechtern gehören, eingesandt in Folge Allerhöchsten Befehls zur Versammlung Deutscher Naturforscher und Aerzte in Kiel im Jahre 1846 aus dem Königlichen particulären zoologischen Musäum. Amtlicher Bericht über die Versammlung Deutscher Naturforscher und Ärzte 24, 122-124.

Bieler, R., Mikkelsen, P.M. \& Giribet, G. In Bieler, R., Mikkelsen, P.M., Collins, T.M., Glover, E.A., GonzÁlez, V.L., Graf, D.L., Harper, E.M., Healy, J., Kawauchi, G.Y., Sharma, P.P., Staubach, S., Strong, E.E., Taylor, J.D., TËmkin, I., Zardus, J.D., Clark, S., GuZmán, A., McIntyre, E., Sharp, P. \& Giribet, G. 2014. Investigating the Bivalve Tree of Life - an exemplar-based approach combining molecular and novel morphological characters. Invertebrate Systematics 28(1), 32-115. DOI 10.1071/IS13010

Binder, H. 2002. Die Land- und Süßwassergastropoden aus dem Karpatium des Korneuburger Beckens (Niederösterreich; Untermiozän). Beiträge zur Paläontologie 27, 161-203.

BindER, H. 2004. Terrestrial, freshwater and brachyhalin Gastropoda from the Lower Miocene deposits of Oberdorf (Steiermark, Österreich). Annalen des Naturhistorischen Museums in Wien, Serie A 105, 189-229.

BINDER, H. 2008. The systematic positions of the genera Pseudochloritis C. Boettger 1909 and Joossia Pfeffer 1930 (Gastropoda: Pulmonata: Helicoidea: Helicidae). Archiv für Molluskenkunde 137, 167-193.

DOI 10.1127/arch.moll/0003-9284/137/167-193

BLANFORD, W.T. 1863. On Indian species of land-shells belonging to the genera Helix, Linn., and Nanina, Gray. Annals and Magazine of Natural History, serie 3 11, 81-86. DOI 10.1080/00222936308681385

Boeters, H.D., Gittenberger, K. \& Subai, P. 1989. Die Aciculidae (Mollusca Gastropoda, Prosobranchia). Zoologische Verhandelungen 252, 1-234.

Boettger, O. 1908. Die fossilen Mollusken der Hydrobienkalke von Budenheim bei Mainz. Nachrichtsblatt der deutschen Malakozoologischen Gesellschaft 40, 145-157.

Boettger, C.R. 1909. Ein Beitrag zur Erforschung der europäischen Heliciden. Nachrichtsblatt der deutschen Malacozoologischen Gesellschaft 41, 1-19, 49-68.

Boettger, C.R. 1911. Einige Worte zu: Noch einmal "Die Verwandtschatsbeziehung der Helixarten aus dem Tertiär Europas" von Prof Dr. O. Boettger in Frankfurt (Main). Nachrichtsblatt der deutschen Malacozoologischen Gesellschaft 43, 99-108, 118-433.

BOETtGer, O. 1870. Revision der tertiaeren Land- und Süsswasser-Versteinerungen des nördlichen Böhmens. Jahrbuch der Kaiserlich-Königlichen Geologischen Reichsanstalt 20, 283-302.

Boettger, O. 1877. Clausilienstudien. Palaeontographica N.F. Supplement 3, 1-122.
Boettger, O. 1884. Fossile Binnenschnecken aus den untermiocänen Corbicula-Thonen von Niederrad bei Frankfurt (Main). Bericht der Senckenbergischen Naturforschenden Gesellschaft 1883/1884, 258-280.

Boettger, O. 1889. Die Entwicklung der Pupa-Arten des Mittelrheingebietes in Zeit und Raum. Jahrbücher des Nassauischen Vereins für Naturkunde 42, 225-327 (1-98 in offprint).

BoEtTGER, O. 1896. Neue Funde tertiärer Landschnccken bei Offenbach a. M. Nachrichtsblatt der deutschen Malakozoologischen Gcscllschaft 28, 16-19.

Bourguignat, J.R. 1857. Aménités Malacologiques, LXIV. Du genre Carychium. Revue et Magasin de Zoologie 2/9/5, 209-232.

Bourguignat, J.R. 1860. Aménités Malacologiques, LXIV. Du genre Carychium. Aménités Malacologiques 2, 51-74 [Extrait de la Revue et Magasin de Zoologie].

Bourguignat, J.R. 1881. Histoire malacologique de la colline de Sansan, précédée suivie d'un aperçu climatologique et topographique de Sansan a époque des deposits de cette colline. Annales des sciences géologiques 11, 49-175.

Braun, A. 1851. Darstellung der geognostischen Verhältnisse des Mainzer Tertiärbeckens und seiner fossilen Fauna und Flora, 1121-1169. In Walchner, F.A. (ed.) Handbuch der Geognosie bei seinen Vorlesungen und zum Selbststudium mit besonderer Berücksichtigung der geognostischen Verhältnisse des Grossherzogthums Baden. 2. Auflage, C. Th. Groos, Karlsruhe.

Bruijn, H. De, Daams, R., Daxner-Höck, G., Fahlbusch, V., Ginsburg, L., Mein, P. \& Morales, J. [with the contribution of Heinzmann, E., Mayhew, D.F., van der Meulen, A.J., Schmidt-Kittler, N., Teller Antunes, M.] 1992. Report of the RCMNS working group on fossil mammals, Reisensburg 1990. Newsletter on Stratigraphy 26(2/3), 65-118. DOI 10.1127/nos/26/1992/65

Brusina, S. 1884. Die Neritodonta Dalmatiens und Slavoniens nebst allerlei malakologischen Bemerkungen. Jahrbücher der Deutschen Malakozoologischen Gesellschaft 11, 17-120.

BurmeIster, H. 1837. Handbuch der Naturgeschichte. Zum Gebrauch bei Vorlesungen. 2. Abt. Zoologie. 858 pp. T.C.F. Enslin, Berlin.

Chemnitz, J.H. 1786. Neues systematisches Conchylien-Cabinet. Neunten Bandes zwote Abtheilung, enthaltend die ausführliche Beschreibung von den Land- und Flußschnecken, oder von solchen Conchylien, welche nicht im Meere, sondern auf der Erde und in süssen Wassern zu leben pflegen. Mit zwanzig nach der Natur gemalten und durch lebendige Farben erleuchteten Kupfertafeln. xxvi + 194 pp. Raspe, Nürnberg. DOI 10.5962/bhl.title.123892

Children, J.G. 1834. Synopsis of the contents of the British Museum. 240 pp. British Museum, London.

Clessin, S. 1877. Die tertiären Binnenconchylien von Undorf. [I.]. Correspondenzblatt des mineralogisch-zoologischen Vereins zu Regensburg 31(3), 34-41

Clessin, S. 1885. Die Conchylien der Obermiocaenen Ablagerungen von Undorf. Malakozoologische Blätter N.F. 7, 71-95.

Cockerell, T.D.A. 1891. On the geographical distribution of slugs. Proceedings of the Zoological Society of London 2, 214-226. DOI 10.1111/j.1096-3642.1891.tb01744.x 
Cooke, C.M. 1921. Notes on Hawaiian Zonitidae and Succineidae. Occasional Papers Bernice P. Bishop Museum 7, 263-277.

Cossmann, M. 1889a. Catalogue illustré des coquilles fossils de l'Éocène des environs de Paris. Annales de la Société Royale Malacologique de Belgique 24, 3-376.

Cossmann, M. 1889b. Gastéropodes, 1079-1109. In Douvillé, H. (ed.) Revue de paléontologie pour l'année 1888. Annuaire Géologique Universel 5.

Cox, L.R. 1960. Thoughts on the classification of the Gastropoda. Proceedings of the Zoological Society of London 33, 239-261.

Cuvier, G. 1795. Second Mémoire sur l'organisation et les rapports des animaux à sang blanc, dans lequel on traite de la structure des Mollusques et de leur division en ordre, lu à la société d'Histoire Naturelle de Paris, le 11 prairial an troisième. Magazin Encyclopédique, ou Journal des Sciences, des Lettres et des Arts 2, 433-449.

DAXNER-Höck, G. 2010. Sciuridae, Gliridae and Eomyidae (Rodentia, Mammalia) from the Middle Miocene of St. Stefan in the Gratkorn Basin (Styria, Austria). Annalen des Naturhistorischen Museums in Wien, Serie A 112, 507-536.

Dedov, I. \& Subai, P. 2012. On Gyralina species from the Macedonian Republic and Greece, with description of new species (Gastropoda: Pulmonata: Pristilomatidae). Archiv für Molluskenkunde 141, 209-215.

DOI 10.1127/arch.moll/1869-0963/141/209-215

Denainvilliers, A.D.F.D. 1875. Description de quelques espèces de Coquilles fossiles des terrains tertiaires des environs de Paris. Journal de Conchyliologie 23(1), 68-75.

Deshayes, G.P. 1855. Catalogue of the Conchifera or bivalve shells in the collection of the British Museum. Part 2, Petricoladae (concluded); Corbiculadae. 217-292 pp. British Museum. London.

Deshayes, G.P. 1863-1864. Description des animaux sans vertèbres découverts dans le bassin de Paris, pour servir de supplément à la description des coquilles fossiles des environs de Paris 2. 41-920 pp. (1963), 921-968 pp. (1964), J.B. Baillière, Paris.

Desmarest, A.G. 1814. Note sur les Ancyles ou Patelles d'eau douce, et particuličrement sur deux espèces de ce genre envore décrites, l'une fossile et l'autre vivante. Bulletin des Sciences, par la Société philomatique de Paris 1814, 18-20.

DoERING, A. 1885. Apuntes sobre la fauna de moluscos de la República Argentina. $5^{\circ}$ entrega. Boletín de la Academia Nacional de Ciencias en Córdoba 7, 457-474.

Draparnaud, J.P.R. 1801. Tableau des mollusques terrestres et fluviatiles de la France. 116 pp. Renaud, Bossange, Masson \& Besson, Montpellier, Paris.

Draparnaud, J.P.R. 1805. Histoire naturelle des mollusques terrestres et fluviatiles de la France. 164 pp. Colas, Paris. DOI 10.5962/bhl.title.12856

Dupuy, D. 1850. Description de quelques espèces de coquilles terrestres fossils de Sansan. Journal de Conchyliologie 1, 300-313.

Eichwald, E. 1829. Zoologia specialis quam expositis animalibus tum vivis, tum fossilibus potissimum Rossiae in universum et Poloniae in specie, in usum lectionum publicarum in Universitate Caesarea Vilnensi habendarum. Pars prior propaedeuticam zoologiae atque specialem heterozoorum expositionem continens. 314 pp. Joseph Zawadzki, Vilnius.

EICHWALD, E. 1830. Naturhistorische Skizze von Lithauen, Volhynien und Podolien in Geognostisch-Mineralogischer, Botanischer und Zoologischer Hinsicht. 256 pp. Voss, Wilna.

ELLIS, A.E. 1926. British snails, a guide to the non-marine Gastropoda of Great Britain and Ireland, Pliocene to Recent. 275 pp. Clarendon Press, Oxford.

FAGOT, P. 1893. Histoire malacologique des Pyrénées Françaises et Espagnoles. Bulletin de la Société Ramond 28(4), 247-262.

FAHLBUSCH, V. 1989. Über den Holotypus von Metacordylodon schlosseri (Andreae 1904) (Insectivora, Mamm.) aus dem Miozän von Opole (Oppeln). Mitteilungen der Bayerischen Staatssammlung für Paläontologie und historische Geologie 29, 159-162.

FALKNER, G. 1974. Über Acanthinulinae aus dem Obermiozän Süddeutschlands. Archiv für Molluskenkunde 104, 229-245.

FALKNER, G. 1986. Protodrepanostoma nordsiecki n. sp. aus dem untermiozänen Landschneckenkalk von Tuchorice/Böhmen (Gastropoda: Hygromiidae). Heldia 1(4), 121-123.

FAVRE, J. 1927. Les mollusques post-glaciaires et actuels du bassin de Genève. Mémoires de la Société de Physique et d'Histoire Naturelle de Genève 40, 171-434,

Fehér, Z., SzABó, K., Bozsó, M. \& Pénzes, Z. 2009. Recent range expansion of Pomatias rivulare (Eichwald, 1829) (Mollusca: Pomatiidae) in Central-Eastern Europe. Acta Zoologica Academiae Scientiarum Hungaricae 55, 67-75.

FÉrussaC, A.E.J.P.J.F. D“A. DE 1821-1822. Tableaux systématiques des animaux mollusques classés en familles naturelles, dans lesquels on a établi la concordance de tous les systèmes; suivis d'un prodrome général pour tous les mollusques terrestres ou fluviatiles, vivants ou fossiles. 110 pp. Bertrand, Sowerby, Paris, Londres.

Férussac, J.B.L. D’A. DE \& Férussac, A.E.J.P.J.F. D’A. DE 1807. Essai d'une méthode conchyliologique appliquée aux mollusques fluviatiles et terrestres d'après la considération de l'animal et de son test, par M. Daudebard de Férussac. Nouvelle édition augmentée d'une synonymie des espèces les plus remarquables, d'une table de concordance systématique de celles qui ont été décrites par Géoffroy, Poiret et Draparnaud, avec Müller et Linné, et terminée par un catalogue d'espèces observées en divers lieux de la France. xvi + 142 pp. Delance, Paris.

FINGER, I. 1998. Gastropoden der kleini-Schichten des Steinheimer Beckens (Miozän, Süddeutschland). Stuttgarter Beiträge zur Naturkunde 259, 1-51.

Fischer, J.C. 2000. La malacofauna de Sansan. Mémoires du Muséum national d'Histoire naturelle 183, 129-154.

Fischer, K. \& WenZ, W. 1914. Die Landschneckenkalke des Mainzer Beckens und ihre Fauna. Nassauischer Verein für Naturkunde 67, 1-154.

Fischer, K. \& WenZ, W. 1916. Das Tertiär in der Rhön und seine Beziehungen zu anderen Tertiärablagerungen. Jahrbuch der Königlich Preussischen Geologischen Landesanstalt 35, 37-75.

FISCHER, P. in PAUlucci, M. 1878. Matériaux pour servir à l'étude de la faune malacologique terrestre et fluviatile de l'Italie et de ses îles. iv +54 pp. Savy, Paris.

FITZINGER, L.I. 1833. Systematisches Verzeichniß der im Erzherzogthume Oesterreich vorkommenden Weichthiere, als 
Prodrom einer Fauna derselben. Beiträge zur Landeskunde Oesterreich's unter der Enns 3, 88-122.

FlaCH, K. 1889. Ueber die tertiären Arten des Genus Acme Hartmann. Bericht der Wetterauischen Gesellschaft für die gesammte Naturkunde zu Hanau 1, 69-77.

Flach, K. 1891. Palaeontologische Beiträge: I. Zur Fauna von Tuchořić in Nordböhmen. Verhandlungen der physikalischmedicinischen Gesellschaft zu Würzburg N.F. 24, 1-49.

Fleming, J. 1820. Mollusca, 598-635. In BRewster, D. (ed.). The Edinburgh Encyclopcedia. In eighteen volumes 14, Blackwood, Edinburgh.

Fleming, J. 1828. A history of British animals, exhibiting the descriptive characters and systematic arrangement of the genera and species of quadrupeds, birds, reptiles, fishes, Mollusca, and Radiata of the United Kingdom; including the indigenous, extirpated, and extinct kinds, together with periodical and occasional visitants. xxiii +565 pp. Bell \& Bradfute, Edinburgh.

Frauenfeld, G. 1864. Vorläufige Aufzählung der Arten der Gattungen Hydrobia Htm. und Amnicola Gld. Hldm. In der kaiserlichen und in Cuming's Sammlung. Verhandlungen der zoologisch-botanischen Gesellschaft in Wien 13, 1017-1032.

FRÝDA, J. 1998. Higher classification of the Paleozoic gastropods inferred from their early shell ontogeny. $13^{\text {th }}$ International Malacological Congress (Washington DC), Abstracts, 108.

GAÁL, I. 1910. A Hunyadmegyei Rákosd szarmatakorú csigafaunája. Magyar Földtani Intézet Èvkönyve 18, 1-96.

Gargominy, O. \& RiPKEn, T.E.J. 2011. Une collection de référence pour la malacofaune terrestre de France: a reference collection for French terrestrial molluscs. MalaCo HS1, $1-108$.

Germain, L. 1929. Les Helicidae de la faune française. Archives du Muséum d'Histoire Naturelle de Lyon 13, 1-484.

GitTEnberger, E. 1979. On Elona (Pulmonata, Eloniadae fam. nov.). Malacologia 18, 139-145.

Gittenberger, E. \& MaAssen, W.J.M. 1980. Hydrocena (H.) cattaroensis (L. Pfeiffer, 1841) (Prosobranchia, Neritacea) und ihre Lebensbedingungen. Basteria 44, 9-10.

Gittenberger, E. \& van Bruggen, A.C. 2013. Land snails of the islet of Misali, off Pemba Island, Zanzibar, Tanzania. Zoologische Mededelingen 87(3), 235-273.

GŁazek, J. \& Szynkiewicz, A. 1987. Stratigraphy of the Late Tertiary and Early Quaternary karst deposits in Poland and their paleogeographic implications, 113-130. In JAHN, A. \& DYJOR, S. (eds) Problemy młodszego neogenu i eaoplejstocenu w Polsce. Zakłady Narodowe Ossolin'skich, Wrocław.

Golikov, A.N. \& Starobogatov, Y.I. 1975. Systematics of prosobranch gastropods. Malacologia 15, 185-232.

GotTsсніск, F. 1911. Aus dem Tertiärbecken von Steinheim a. A. Jahreshefte des Vereins für vaterländische Naturkunde in Württemberg 67, 496-534.

Gotтsсніск, F. 1920. Die Land- und Süßwassermollusken des Tertiärbeckens von Steinheim am Aalbuch. Archiv für Molluskenkunde 52, 33-66, 108-117, 163-177.

GotTsсHICK, F. 1921. Die Land- und Süßwassermollusken des Tertiärbeckens von Steinheim am Aalbuch. 7. Fortsetzung. Archiv für Molluskenkunde 53(3), 163-181.

Gotтschick, F. \& Wenz, E. 1916. Die Sylvanaschichten von Hohenmemmingen und ihre Fauna. Nachrichtsblatt der Deutschen Malakozoologischen Gesellschaft 1916, 17-113.
Gottschick, F. \& Wenz, W. 1919. Die Land- und Süsswassermollusken des Tertiärbeckens von Steinheim am Aalbuch. I. Die Vertiginiden. Nachrichtsblatt der Deutschen Malakozoologischen Gesellschaft 51, 1-23.

GotTschick, F. \& Wenz, W. 1921. Ueber "Pupa aperta" Sandberger. Archiv für Molluskenkunde 53, 212-213.

Gould, A.A. 1841. Report on the Invertebrata of Massachusetts, comprising the Mollusca, Crustacea, Annelida, and Radiata. Published agreeably to an order of the legislature, by the comissioners on the Zoological and Botanical Survey of the state. xiii +373 pp. Forsom, Wells \& Thurston, Cambridge.

Gozhik, P.F. \& Prysuazhnun, V.A. 1978. Presnovodnyye i nazemnyye mollyuski miotsena Pravoberezhnoy Ukrainy. 172 pp., 40 pls. Ed. AN UkdrSSR ("Naukova Dumka"), Kiev.

GRAY, J.E. 1840. Shells of molluscous animals. Synopsis of the contents of the British Museum 42, 105-152, 106-156 (second printing).

GrAY, J.E. 1847. A list of the genera of recent Mollusca, their synonyma and types. Proceedings of the Zoological Society of London 15, 129-219.

GRAY, J.E. 1850. Figures of molluscous animals selected from various authors. Etched fort he use of students by M. E. Gray, volume 4. iv + 219 pp. Longman, Brown, Green \& Longmans, London.

GRAY, J.E. 1855. Catalogue of Pulmonata or air-breathing Mollusca in the collection of the British Museum. Part 1, 192 pp. Taylor \& Francis, London.

GudE, G.K. 1913. The helicoid land shells of the Fiji Islands, with definitions of three new genera and descriptions of four new species. Proceedings of the Malacological Society of London 10, 325-330.

HaBe, T. 1964. Two new land snails from Japan. Venus 23, 39-42.

Haller, B. 1890. Die Morphologie der Prosobranchier, gesammelt auf einer Erdumsegelung durch die königl italienische Korvette "Vettor Pisani". II. Morphologisches Jahrbuch 16, 259-298.

Handmann, R. 1887. Die fossile Conchylienfauna von Leobersdorf im Tertiärbecken von Wien. 15 pp. Aschendorff, Münster.

Hartmann, J.D.W. 1821. System der Erd- und Flußschnecken der Schweiz. Mit vergleichender Aufzählung aller auch in den benachbarten Ländern, Deutschland, Frankreich und Italien sich vorfindenden Arten. Neue Alpina 1, 194-268.

Harzhauser, M. \& Binder, H. 2004. Pannonian Molluscs from the sections Richardhof and Eichkogel in the Vienna Basin (Austria, Late Miocene). Archiv für Molluskenkunde 133, 109-165.

Harzhauser, M. \& Kowalke, T. 2002. Sarmatian (Late Middle Miocene) Gastropod Assemblages of the Central Paratethys. Facies 46, 57-82. DOI 10.1007/BF02668073

Harzhauser, M. \& Piller, W.E. 2007. Benchmark data of a changing sea - Palaeogeography, palaeobiogeography and events in the Central Paratethys during the Miocene. Palaeogeography, Palaeoclimatology, Palaeoecology 253, 8-31. DOI 10.1016/j.palaeo.2007.03.031

Harzhauser, M., Daxner-Höck, G., GöHlich, U.B. \& Nagel, D. 2011. Complex faunal mixing in the early Pannonian palaeo-Danube Delta (Late Miocene, Lower Austria). Annalen des Naturhistorischen Museums in Wien, Serie A 113, 167-208. 
Harzhauser, M., Gross, M. \& Binder, H. 2008. Biostratigraphy of Middle Miocene (Sarmatian) wetland systems in an Eastern Alpine Intramontane Basin (Gratkorn Basin, Austria): the terrestrial gastropod approach. Geologica Carpathica 59, 45-58.

Harzhauser, M., Neubauer, T.A., Georgopoulou, E., Esu, D., D‘Amico, C., Pavia, G., Giuntelli, P. \& Carnevale, G. 2015. Late Messinian continental and Lago-Mare gastropods from the Tertiary Piedmont Basin, NW Italy. Bollettino della Società Paleontologica Italiana 54(1), 1-53.

\section{DOI 10.4435/BSPI.2015.1}

Harzhauser, M., Neubauer, T.A., Georgopoulou, E. \& Harl, J. 2014a. The Early Miocene (Burdigalian) mollusc fauna of the North Bohemian Lake (Most Basin). Bulletin of Geosciences 89, 819-908. DOI 10.3140/bull.geosci.1503

Harzhauser, M., Neubauer, T.A., Gross, M. \& Binder, H. 2014b. The early Middle Miocene mollusc fauna of Lake Rein (Eastern Alps, Austria). Palaeontographica A 302, 1-71. DOI 10.1127/pala/302/2013/1

HaszPrunar, G. \& Huber, G. 1990. On the central nervous system of Smeagolidae and Rhodopidae, two families questionably allied with the Gymnomorpha (Gastropoda, Euthyneura). Journal of Zoology 220, 185-199. DOI 10.1111/j.1469-7998.1990.tb04302.x

Hausdorf, B. 1995. Eine miozäne Orcula aus Mitteleuropa (Gastropoda: Orculidae). Heldia 2(3/4), 73-74.

HERRMANNSEN, A.N. 1846-1847. Indicis generum malacozoorum primordia. Nomina subgenerum, generum, familiarum, tribuum, ordinum, classium; adjectis auctoribus, temporibus, locis systematicis atque literariis, etymis, synonymis. Praetermittuntur Cirripedia, Tunicata et Rhizopoda. Vol. I, xxvii +637 pp. Fischer, Cassellis.

Hesse, P. 1927. Systematische Anordnung der extramarinen Gastropoden der deutschen Fauna, 45-48. In GeYER, D. (ed.) Unsere Land- und Süßwassermollusken. $3^{\text {rd }}$ edition, 262 pp. G. Lutz' Verlag, Stuttgart.

Heynemann, F.D. 1863. Einige Mittheilungen der Schneckenzungen mit besonderer Beachtung der Gattung Limax. Malakozoologische Blätter 10, 200-216.

HöltKe, O., Salvador, R.B. \& Rasser, M.W. 2016. Paleobiogeography of Early/Middle Miocene terrestrial gastropods in Central Europe: an approach using similarity indices. Palaeogeography, Palaeoclimatology, Palaeoecology 461, 224-236. DOI 10.1016/j.palaeo.2016.08.027

HöRNES, M. 1851-1856. Die fossilen Mollusken des Tertiär-Beckens von Wien. I. Univalven. Abhandlungen der Kaiserlich-Königlichen Geologischen Reichsanstalt 3, 461-736.

Hudec, V. 1965. Neue Erkenntnisse über die Anatomie von Argna bielzi (Rossmässler) und Bemerkungen zur systematischen Stellung der Gattung Argna Cossmann. Archiv für Molluskenkunde 94, 157-163.

Hyman, I.T. \& Ponder, W.F. 2010. A morphological phylogenetic analysis and generic revision of Australian Helicarionidae (Gastropoda: Pulmonata: Stylommatophora), and an assessment of the relationships of the family. Zootaxa 2462, 1-148.

IREDALE, T. 1944. The land Mollusca of Lord Howe Island. Australian Zoologist 10, 299-334.

Ivanov, M. 2001. Changes in the composition of the European snake fauna during the early Miocene and at the early/middle
Miocene transition. Paläontologische Zeitschrift 74(4), 563-573. DOI 10.1007/BF02988162

JACKIEWICZ, M. 1998. European species of the family Lymnaeidae (Gastropoda: Pulmonata: Basommatophora). Genus 9, 1-93.

JEFFREYS, J.G. 1830. A synopsis on the testaceous pneumonobranchous Mollusca of Great Britain. Transactions of the Linnean Society of London 16, 323-392. DOI 10.1111/j.1095-8339.1829.tb00139.x

Jochum, A., Neubauer, T.A. \& Harzhauser, M. 2016. Microstructural details in shells of the gastropod genera Carychiella and Carychium of the Middle Miocene. Lethaia 49, 87-101. DOI 10.1111/let.12134

Jochum, A., Weigand, A.M., Bochud, E., Inäbnit, T., Dörge, D.D., Ruthensteiner, B., Favre, A., Martels, G. \& Kampschulte, M. 2017. Three new species of Carychium O.F. Müller, 1773 from the Southeastern USA, Belize and Panama are described using computer tomography (CT) (Eupulmonata, Ellobioidea, Carychiidae). ZooKeys 675, 97-127. DOI 10.3897/zookeys.675.12453

Jooss, C.H. 1911a. Neue Binnenconchylien aus dem Hydrobienschichten des Hessler. Centralblatt für Mineralogie, Geologie und Paläontologie 1911, 705.

Jooss, C.H. 1911b. Die Molluskenfauna der Hydrobienschichten des Hessler bei Mosbach-Biebrich. Jahrbücher des Nassauischen Vereins für Naturkunde 64, 50-75.

Jooss, C.H. 1912. Neue Landschnecken aus dem Obermiocän von Steinheim am Aalbuch in Württemberg. Nachrichtsblatt der Deutschen malakozoologischen Gesellschaft 44, 30-74.

Jooss, C.H. 1918. Vorläufige Mitteilung über tertiäre Land- und Süßwasser-Mollusken. Centralblatt für Mineralogie, Geologie und Paläontologie 17/18, 287-294.

KadOLSKY, D. 2008. Molluks from the Late Oligocene of Oberleichtersbach (Rhön Mountains, Germany). Part 2: Gastropoda: Neritimorpha and Caenogastropoda. Courier Forschungsinstitut Senckenberg 260, 103-137.

KADOLSKY, D. 2017. On the type species of the genus Galactochilus Sandberger, 1875, with a review of the identity of Helix cornumilitare Linnaeus 1758 and of its misidentifications (Gastropoda: Helicoidea). Archiv für Molluskenkunde 146(1), 97-110. DOI 10.117/arch.moll/146/097-110

Kadolsky, D. \& Piechocki, A. 2000. Freshwater Rissooidea from the Miocene of Bełchatów, Poland (Gastropoda Prosobranchia: Hydrobiidae, Pomatiopsidae). Archiv für Molluskenkunde 128, 217-236.

Kadolsky, D., Binder, H. \& Neubauer, T.A. 2016. Taxonomic review of the fossil land gastropod species hitherto placed in the genus Galactochilus Sandberger 1875, with the description of a new genus (Gastropoda: Helicoidea). Archiv für Molluskenkunde 145(2), 151-188.

DOI 10.1127/arch.moll/145/151-188

Kantor, Y.I., Vinarski, M.V. Schileyko, A.A. \& Sysoev, A.V. 2010. Catalogue of the continental mollusks of Russia and adjacent territories. Version 2.3.1.

http://www.ruthenica.com/documents/Continental_Russian_ molluscs_ver2-3-1.pdf

Kawase, M., Hayase, Y. \& Ichihara, T. 2011. Land mollusks in Toyota City, Aichi Prefecture, central Japan. Science report of the Toyohashi Museum of Natural History 21, 31-43.

Kawase, M., Murase, F., Hayase, Y. \& Ichihara, T. 2012. Ter- 
restrial mollusks in riparian forests along the upper and middle reach of Yahagi River. Yahagigawakenkyuu 16, 11-26.

Kerney, M.P., Cameron, R.A.D. \& Jungbluth, J.H. 1983. Die Landschnecken Nord- und Mitteleuropas. 384 pp. Paul Parey Verlag, Hamburg, Berlin.

KLEIN, A. von 1846. Conchylien der Süsswasserkalkformation Württembergs. Jahreshefte des Vereins für vaterländische Naturkunde in Württemberg 2, 60-116.

KLEIN, A. vON 1853. Conchylien der Süsswasserkalkformation Württembergs. Jahreshefte des Vereins für vaterländische Naturkunde in Württemberg 9, 203-223.

KLIKA, G. 1891. Die tertiären Land- und Süßwasserconchylien des nordwestlichen Böhmen. Archiv der naturwissenschaftlichen Landesdurchforschung von Böhmen 7(4), 1-122.

Koвelt, W. 1904. Iconographie der Land- \& SüsswasserMollusken mit vorzüglicher Berücksichtigung der europäischen noch nicht abgebildeten Arten von E. A. Rossmässler. Neue Folge. Elfter (Register-) Band. xii +342 pp. Kreidel, Wiesbaden.

Kobelt, W. \& MöllendoRfF, O. von 1898. Die Binnenmollusken Annams. Nachrichtsblatt der Deutschen Malakozoologischen Gesellschaft 30, 129-160.

KóKAY, J. 2006. Nonmarine mollusc fauna from the Lower and Middle Miocene, Bakony Mts., W Hungary. Geologica Hungarica, Series Palaeontologica 56, 1-196.

KorotKIEVICH, E.L. \& SulimsKi, A. 1990. A new chalicotherian finding from the Miocene karst in Poland (Mammalia, Badenian). Acta Palaeontolgica Polonica 35, 91-96.

Kowalski, K. 1967. Rodents from the Miocene of Opole. Acta Zoologica Cracoviensia 12, 1-18.

Kowalski, K. 1990. Stratigraphy of Neogene mammal chronology of Poland, 193-209. In Lindsay, E.H., FAhlBusch, V. \& MeIn, P. (eds) European Neogene Mammal Chronology. Plenum Press, New York.

KowALSKI, K. 1994. Evolution of (Anomalomys Gaillard, 1900 (Rodentia, Mammalia) in the Miocene of Poland. Acta Zoologica Cracoviensia 37, 163-176.

Kowalski, K. \& RzebiK-Kowalska, B. 2002. Paleoecology of the Miocene fossil mammal fauna from Belchatów (Poland). Acta Theriologica 47 (Supplement 1), 115-126. DOI 10.1007/BF03192483

KuIPER, J.G.J. 1972. Sphaeriidenfunde in den pliozänen Deckschichten der rheinischen Braunkohle. Archiv für Molluskenkunde 102(1/3), 125-130.

Küster, H.C. 1844. Zoologische Notizen. Isis 1844(9), 645-656.

LAMARCK, J.B.P.A. DE M. DE 1799. Prodrome d'une nouvelle classification des coquilles, comprenant une rédaction appropriée des caractères génériques, et l'établissement d'un grand nombre de genres nouveaux. Mémoires de la Société d'Histoire Naturelle de Paris 1, 63-91.

LAMARCK, J.B.P.A. DE M. DE 1801. Systême des animaux sans vertèbres, ou tableau général des classes, des ordres et des genres de ces animaux, présentant leurs caractères essentiels et leur distribution, d'après la considération de leurs rapports naturels et de leur organisation, et suivant l'arrangement établi dans les galeries du Muséum d'Hist. Naturelle, parmi leurs dépouilles conservées; précédé du discours d'ouverture du Cours de Zoologie, donné dans le Muséum National d'Histoire Naturelle l'an 8 de la République. viii + 432 pp. Deterville, Paris.
LEA, I. 1841. Description of nineteen new species of Colimacea. Transactions of the American Philosophical Society, New Series 7, 455-465.

Leeuw, A. De, Bukowski, K., Krijgsman, W. \& Kuiper, K.F. 2010. Age of the Badenian salinity crisis; impact of Miocene climate variability on the circum Mediterranean region. Geology $38,715-718$. DOI 10.1130/G30982.1

LinDHOLM, W.A. 1926. Beiträge zur Kenntnis der paläarktischen Planorbidae. Archiv für Molluskenkunde 58, 241-258.

LindHOLM, W.A. 1927. Zur Systematik und Nomenklatur einiger Heliciden und ihrer Verwandten. Archiv für Molluskenkunde 59, 116-138.

LinNaeus, C. 1758. Systema naturae per regna tria naturae, secundum classes, ordines, genera, species, cum characteribus, differentiis, synonymis locis. Tomus $1.10^{\text {th }}$ edition, 824 pp. Laurentius Salvius, Holmiae.

Lowe, R.T. 1831. Primitiæ faunæ et floræ Maderæ et Portus Sancti; sive species quædam novæ vel hactenus minus rite cognitæ animalium et plantarum in his insulis degentium breviter descriptæ. Transactions of the Cambridge Philosophical Society 4, 1-70.

LowE, R.T. 1852. Brief diagnostic notices of new Maderan land shells. Annals and Magazine of Natural History 2/9/50, 112-120, 275-279.

Lueger, J.P. 1981. Die Landschnecken im Pannon und Pont des Wiener Beckens. Denkschriften der Österreichischen Akademie der Wissenschaften, Mathematisch-naturwissenschaftiche Klasse 120, 1-124. DOI 10.1007/978-3-7091-5513-4

Mandic, O. \& Harzhauser, M. 2003. Molluscs from the Badenian (Middle Miocene) of the Gaindorf Formation (Alpine Molasse Basin, NE Austria) - Taxonomy, Paleoecology and Biostratigraphy. Annalen des Naturhistorischen Museums in Wien, Serie A 104, 85-127.

Manganelli, G. \& Giusti, F. 2000. Drepanostoma helenae, a new helicodontine land snail from the Lower Pliocene of Balze d Caspreno near Siena (central Italy) and a discussion on the status of Protodrepanostoma Germain, 1929 (Gastropoda, Pulmonata: Hygromiidae). Bollettino della Società Paleontologica Italiana 39, 351-358.

Manganelli, G., Giusti, F. \& Delle Cave, L. 1990. Notulae Malacologicae, XLVII. Lauriinae (Gastropoda: Pulmonata, Orculidae/Pupillidae) from the Villafranchian of the peninsular Italy. Basteria 53, 87-103.

Manganelli, G., Martini, I. \& Benocci, A. 2011. A new Janulus species (Gastropoda, Pulmonata, Gastrodontidae) from the Zanclean (early Pliocene) of Tuscany (central Italy). Bollettino della Società Paleontologica Italiana 50, 165-173. DOI 10.4435/BSPI.2011.15

Martens, E. 1864. Über neue Cyclostomaceen und Helicinen aus dem indischen Archipel. Monatsberichte der Königlichen Preussischen Akademie der Wissenschaften zu Berlin 1864, 116-121.

Mason, C.F. 1970. Snail populations, beech litter production, and the role of snails in litter decomposition. Oecologia 5, 215-239. DOI 10.1007/BF00344885

Mein, P. 2009. The Miocene Keramidomys (Rodentia, Eomyidae) from the Sandelzhausen locality (Germany). Paläontologische Zeitschrift 83, 141-150. DOI 10.1007/s12542-009-0003-y 
Michael, R. 1902. Tertiäre Landschnecken von Königlich Neudorf bei Oppeln. Zeitschrift der deutschen geologischen Gesellschaft. Verhandlungen der Gesellschaft 54, 12.

Michael, R. 1904. Ueber das Vorkommen einer tertiären Landschneckenfauna im Bereich der jüngsten Schichten der Kreidescholle von Oppeln. Jahrbuch der Preußischen Geologischen Landesanstalt und Bergakademie für das Jahr $190122,372-381$.

Michaud, A.L.G. 1855. Descriptions de coquilles fossiles découvertes dans les environs de Hauterive (Drôme). Annales de la Societé Linnéenne de Lyon, N. S. 2, 33-64.

Miller, K. 1900. Die Schneckenfauna des Steinheimer Obermiocäns. Jahreshefte des Vereins für vaterländische Naturkunde in Württemberg 56, 385-406.

Mitrović, B. 2016. The early Miocene terrestrial and freshwater snails from Sibnica (Levač basin, Serbia), 49-56. In Marković, Z. \& Milivojević, M. (eds) Life on the shore-geological and paleontological research in the Neogene of Sibnica and vicinity (Levač basin, Central Serbia). Part 1. Special Issue of the Natural History Museum in Belgrade.

MŁynarski, M., Szyndlar, Z., Estes, R. \& Sanchíz, B. 1982. Lower vertebrate fauna from the Miocene of Opole (Poland). Estudios Geológicos 38, 103-119.

MoAyedPour, E. 1977. Geologie und Paläontologie des tertiären "Braunkohlenlagers" von Theobaldshof/Rhön (Miozän, Hessen). Geologische Abhandlungen Hessen 76, 1-135.

MöllENdDRFF, O.F. voN 1893. Materialien zur Fauna der Philippinen. XI. Die Insel Leyte. Bericht der Senckenbergischen Naturforschenden Gesellschaft in Frankfurt a. M. 1893, 51-154.

Montagu, G. 1803. Testacea Britannica, or natural history of British shells, marine, land, and fresh-water, including the most minute: systematically arranged and embellished with figures. xxxvii + $606 \mathrm{pp}$. White, London.

Monterosato, T.A. di 1892. Molluschi terrestri delle isole adiacenti alla Sicilia. Atti della Reale Accademia di Scienze, Lettere e Belle Arti di Palermo 3(2), 1-33.

Moquin-TAndon, A. 1856. Histoire naturelle des mollusques terrestres et fluviatiles de la France contenant des études générales sur leur anatomie et leur physiologie et la description particulière des genres, des espèces et des variétés. Tome second, 646 pp. Baillière, Paris.

Mörch, O.A.L. 1864. Fortegnelse over de i Danmark forekommende Land- og Ferskvandsblöddyr. Videnskabelige Meddelelser fra den naturhistoriske Forening i Kjöbenhavn (2) 1863(17-22), 265-367.

Mörch, O.A.L 1872. Catalogue des mollusques terrestres et fluviatiles des ancienes colonies danoides du Golfe du Bengale. Journal de Conchyliologie 20, 303-345.

MorsE, E.S. 1864. Observations on the terrestrial Pulmonifera of Maine, including a catalogue of all the species of terrestrial and fluviatile Mollusca known to inhabitat the state. Journal of the Portland Sociey to Natural History 1, 1-63.

Morton, J.E. 1954. Notes on the ecology and annual cycle of Carychium tridentatum at Box Hill. Proceedings of the Malacological Society of London 81, 30-46.

DOI 10.1093/oxfordjournals.mollus.a064723

Morton, J.E. 1955. The evolution of the Ellobiidae with a discussion on the origin of the Pulmonata. Proceedings of the Zoo- logical Society of London 125, 127-168.

DOI 10.1111/j.1096-3642.1955.tb00596.x

Moser, M., NiederhöFer, H.J. \& FALKNeR, G. 2009. Continental molluscs of the fossil site Sandelzhausen (Miocene; Upper Freshwater Molasse from Bavaria) and their value for palaeoecological assessment. Paläontologische Zeitschrift 83, 25-54. DOI 10.1007/s12542-009-0013-9

Mousson, A. 1865. Coquilles terrestres et fluviatiles de quelques Îles de l'Océan Pacifique, recueillies par M. le Dr. E. Graeffe. Journal de Conchyliologie 13, 164-209.

Mousson, A. 1887. Coquilles terrestres et fluviatiles recueillies par M. Louis Graeser, dans le Bassin de l'Amour. Journal de Conchyliologie 22, 10-32.

MüLLER, O.F. 1773-1774. Vermivm terrestrium et fluviatilium, seu animalium infusoriorum, helminthicorum et testaceorum, non marinorum, succincta historia. xxxiii +135 , xxxvi +214 pp. Heineck \& Faber, Havniae \& Lipsiae.

NeKola, J.C. \& Coles, B.F. 2010. Pupillid land snails of eastern North America. American Malacological Bulletin 28, 29-57. DOI 10.4003/006.028.0221

Neubauer, T.A. 2017. Perpolita H.B. Baker, 1928. In MolluscaBase (2017).

http://www.molluscabase.org/aphia.php? $p=$ taxdetails $\& i d=9$ 34057 on 2017-06-11.

Neubauer, T.A., Harzhauser, M., Georgopoulou, E., Kroh, A. \& MAndic, O. 2015. Tectonics, climate, and the rise and demise of continental aquatic species richness hotspots. Proceedings of the National Academy of Sciences of the United States of America 112(37), 11478-11483.

DOI 10.1073/pnas.1503992112

Neubauer, T.A., Harzhauser, M., Mandic, O. \& Jovanović, G. 2017. The late middle Miocene non-marine mollusk fauna of Vračević (Serbia): filling a gap in Miocene land snail biogeography. Bulletin of Geosciences 91(4), 731-778. DOI 10.3140/bull.geosci.1639

Neubauer, T.A., Mandic, O., Harzhauser, M. \& Hrvatović, H. 2013. A new Miocene lacustrine mollusc fauna of the Dinaride Lake System and its palaeobiogeographic, palaeoecologic, and taxonomic implications. Palaeontology 56(1), 129-156. DOI 10.1111/j.1475-4983.2012.01171.x

Neubert, E. \& Bouchet, P. 2015. The Diplommatinidae of Fiji a hotspot of Pacific land snail biodiversity (Caenogastropoda, Cyclophoroidea), ZooKeys 487, 1-85.

DOI 10.3897/zookeys.487.8463

Neumayr, M. 1884. Zur Morphologie des Bivalvenschlosses. Sitzungsberichte der Akademie der Wissenschaften Wien 88, 385-419.

NeviLl, G. 1880. On the land-shells, extinct and living, of the neighbourhood of Menton (Alpes Maritimes); with descriptions of a new genus and of several new species. Proceedings of the Zoological Society of London 1880, 94-142.

Newton, R.B. 1891. On the necessity for the abandonment of the generic name Cyclostoma, with suggestions relating others involved in this genus. Annals and Magazine of Natural History 6(7), 345-348. DOI 10.1080/00222939109460621

Nordsieck, H. 1972. Fossile Clausilien, I. Clausilien aus dem Pliozän W-Europas. Archiv für Molluskenkunde 102, 165-188.

Nordsieck, H. 1981a. Fossile Clausilien, V. Neue Taxa neogener Clausilien, II. Archiv für Molluskenkunde 111, 63-95. 
Nordsieck, H. 1981b. Fossile Clausilien, VI. Die posteozänen tertiären Clausilien Mittel- und West-Europas. Archiv für Molluskenkunde 111, 97-114.

NoRDSIECK, H. 1982. Zur Stratigraphie der neogenen Fundstellen der Clausiliidae und Triptychiidae Mittel- und Westeuropas (Stylommatophora, Gastropoda). Mitteilungen der Bayerischen Staatssammlung für Paläontologie und Historische Geologie 22, 137-155.

NordsiECK, H. 1986. Das System der tertiären Helicoidea Mitte1- und Westeuropas (Gastropoda: Stylommatophora). Heldia l(4), 109-120.

Nordsieck, H. 2000. Annotated check-list oft he fossil (pre-Pleistocene) Clausiliidae (Gastropoda: Stylommatophora) from central and western Europe. Mitteilungen der deutschen malakozoologischen Gesellschaft 65, 1-15.

Nordsieck, H. 2007. Worldwide Door Snails (Clausiliidae), recent and fossil. 214 pp., 20 pls. ConchBooks, Hackenheim.

NoRDSIECK, H. 2014. Annotated check-list of the genera of fossil land snails (Gastropoda: Stylommatophora) of western and central Europe (Cretaceous - Pliocene), with description of new taxa. Archiv für Molluskenkunde 143(2), 153-185.

DOI 10.1127/arch.moll/1869-0963/143/153-185

Nordsieck, H. 2017. Pulmonata, Stylommatophora, Helicoidea: systematics with comments. 98 pp. ConchBooks, Harxheim.

Noulet, J.B. 1854. Mémoires sur les coquilles fossiles des Terrains d'eau douce du Sud-Ouest de la France. 127 pp. Masson, Paris.

Olivi, G. 1792. Zoologia Adriatiaca ossia catalogo ragionato degli animali del Golfo e delle Lagune di Venezia; preceduto da una dissertazione sulla storia fisica e naturale del Golfo; $e$ accompagnato da memoire, ed osservazioni di fisica storia naturale ed economia. $8+$ xxxii +334 pp., Bassano.

PAladilHE, A. 1868. Nouvelles miscellanées malacologiques. Monographie du genre Acme. Revue et Magasin de Zoologie pure et appliquée et de Sériciculture Comparée 2(20), 225-245, 273-283, 321-330.

Páll-Gergely, B., Hunyadi, A. \& Asami, T. 2015. A new Chinese species of Eostrobilops Pilsbry, 1927 with a checklist of Eostrobilops and Enteroplax Gude, 1897 species (Gastropoda, Pulmonata, Strobilopsidae). Zookeys 508, 85-95. DOI 10.3897/zookeys.508.10004

Páll-Gergely, B., Hunyadi, A., Asami, T. 2017. A new diplommatinid genus and two new species from the Philippines (Gastropoda, Caenogastropoda, Cyclophoroidea). ZooKeys 678, 1-10. DOI 10.3897/zookeys.678.13059

PAPP, A. \& Thenius, E. 1954. Vösendorf - ein Lebensbild aus dem Pannon des Wiener Beckens. Mitteilungen der geologischen Gesellschaft in Wien 46, 2-109.

PawŁowska-Banasiak, E. 2008. Shell, genital and colour variation in Perforatella incarnata (O. F. Müller, 1774) and P. vicina (Rossmässler, 1842) (Gastropoda: Pulmonata: Helicidae). Folia Malacologica 16(2), 89-99.

DOI 10.12657/folmal.016.013

PfeiffER, C. 1821. Naturgeschichte deutscher Land- und Süsswasser-Mollusken. Erste Abtheilung. x + 134 pp. Landes-Industrie-Comptoir, Weimar.

PfefFER, G. 1930. Zur Kenntnis tertiärer Landschnecken. Geologisch-Paläontologische Abhandlungen 3, 1-230.

Pfeiffer, L. 1841. Beiträge zur Molluskenfauna Deutschlands, insbesondere der österreichischen Staaten. Archiv für Naturgeschichte 7, 215-230.

PfeIFFER, L. 1847. Diagnosen neuer Heliceen. Zeitschrift für Malakozoologie 4, 12-16.

Pfeiffer, L. 1854. Zur Molluskenfauna der Insel Cuba. Malakozoologische Blätter 1, 170-213.

PfEIFFER, L. 1857. Verzeichniss der bisher bekannt gewordenen gedeckelten Landschnecken von Cuba. Malakozoologische Blätter 3, 118-150.

Pfeiffer, L. 1865. Die Mollusken der Dobrudscha. Malakozoologische Blätter 12, 100-105.

Piechocki, A. 1997. Mioceńskie mięczaki wodne (Mollusca aquatica) z bełchatowskich złóż węgla brunatnego. Kwartalnik AGH, Geologia 23, 103-120.

Pilsbry, H.A. 1927. Heldicinae, 223-246. In BAKER, H.B. (ed.) Minute Mexican land snails. Proceedings of the Academy of Natural Sciences of Philadelphia 79.

PILSBRY, H.A. 1893. Preliminary outline of a new classification of the Helices. Proceedings of the Academy of Natural Sciences of Philadelphia 44, 387-404.

Pilsbry, H.A. 1893-1895. Manual of Conchology: Structural and Systematic, with illustrations of the species. Second series: Pulmonata. Vol. IX. (Helicidae Vol. 7) Guide to the study of Helices. Part 33: pp. 1-48, pl. 1-14 (1893); Part 34: pp. 49-112, pl. 15-28 (1894); Part 35: pp. 113-160, pl. 29-40 (1894); Part 36: pp. 161-336, pl. 41-71 (1895); Part 33a: pp. i-xlviii (1895); Index (Appendix): pp. 1-126 (1895). Academy of Natural Sciences, Philadelphia.

Pilsbry, H.A. 1900. On the zoological position of Partula and Achatinella. Proceedings of the Academy of Natural Sciences of Philadelphia 52, 561-567.

Pilsbry, H.A. 1907-1908. Manual of Conchology, Second Series: Pulmonata, 19. Oleacinidae. Ferussacidae. Part 73: pp. 1-64, pl. 1-10 (1907); Part 74: pp. 65-128, pl. 11-20 (1907); Part 75: pp. 129-192, pl. 21-30 (1907); Part 76: pp. 193-366, i-xxvii, figs 1-3, pl. 31-52 (1908). Academy of Natural Sciences of Philadelphia, Philadelphia.

Pilsbry, H.A. 1908. Two genera of land snails new to Japan and Korea. The Conchological Magazine 2(8), 39-42.

Pilsbry, H.A. 1916-1918. Manual of Conchology, Second Series: Pulmonata, 24. Pupillidae (Gastrocoptinae). Part 93: pp. 1-112, pl. 1-13 (1916); Part 94: pp. 113-176, pl. 14-29 (1917); Part 95: pp. 177-256, fig. 17, pl. 30-38 (1917); Part 96: pp. 257-380, i-xii, fig. 1, pl. 39-49 (1918). Academy of Natural Sciences, Philadelphia.

Pilsbry, H.A. 1922-1926. Manual of Conchology, Second Series: Pulmonata, 27. Pupillidae (Orculinae, Pagudolinae, Acanthinulinae, etc.). Part 105: pp. 1-8, pl. 1-5 (1922); Part 106: pp. 81-128, pl. 6-11 (1923); Part 107: pp. 129-176, pl. 12-18 (1924); Part 108: pp. 177-369, i-iv, figs 1-17, pl. 19-32 (1926). Academy of Natural Sciences, Philadelphia.

Pilsbry, H.A. 1927-1935. Manual of Conchology, Second Series: Pulmonata, 28. Geographic Distribution of Pupillidae; Strobilopsidae, Valloniidae and Pleurodiscidae. Part 109: pp. 1-48, figs 1-2, pl. 1-8 (1927); Part 110: pp. 49-96, pl. 9-12 (1931); Part 111: pp. 97-160, figs 3-8, pl. 13-23 (1934); Part 112: pp. 161-226, i-xii, figs 9-12, pl. 24-31 (1935), Academy of Natural Sciences, Philadelphia.

PrisyaZhNYUK, V.A. 1973. Terrestrial molluscs from Middle 
Sarmatian in Moldavian Pridnestrov, 57-75. In Negadev-Nikonov, K.N. (ed.) Fauna of the Late Caenozoic in Moldavia. Shtiintza, Kishinev.

Prisyazhnyuk, V.A. \& Stworzewicz, E. 1995. Notes on the genera Carychiopsis Sandberger, 1872 and Carychium of Mueller, 1774 from the Neogene of Europe. Acta Zoologica Cracoviensia 38, 267-270.

ProćKów, M. 2009. The genus Trochulus Chemnitz, 1786 (Gastropoda: Pulmonata: Hygromiidae) - a taxonomic revision. Folia Malacologica 17(3), 101-176.

DOI 10.2478/v10125-009-0013-0

Prysiazhniuk, V.A. 2016. Occurrence and complexes of terrestrial mollusks from the Neogene of the south-eastern part of the east European craton. Geologichnyy Zhurnal 355, 63-72.

PrysyazhniUK, V.A. 2014. Occurrence and komplexes of terrestrial mollusks from the middle Sarmatian of the eastern Volyno-Podillya. Geologichnyy Zhurnal 4, 75-82.

PrysyazhniUK, V.A. 2015a. Leiostyla Love, 1852 - Mollusca, Pulmonata - new fossils for the Neogene Serbia and Ukraine. Reports of the National Academy of Sciences of Ukraine 2015(1), 92-98.

PrysyazhniUK, V.A. 2015b. Main occurrences of the terrestrial mollusks in the Sarmatian deposits of Moldova. Geologichnyy Zhurnal 352, 69-76.

Pulteney, R. 1799. Catalogues of the birds, shells, and some of the more rare plants, of Dorsetshire. From the new and enlarged edition of Mr. Hutchins's history of that county. $92 \mathrm{pp}$. Nichols, London.

RAFINESQUE, C.S. 1815. Analyse de la nature ou tableau de l'univers et des corps organisés. 223 pp. Privately published, Palermo.

REINHARDT, O. 1871. Über die in Deutschland vorkommenden Hyalinen aus der Crystallina-Gruppe. Sitzungsberichte der Gesellschaft Naturforschender Freunde zu Berlin 1871, 39-40.

ReINHARDT, O. 1877. Diagnosen japanischer Landschnecken. Jahrbücher der Deutschen Malakozoologischen Gesellschaft 4, 320-329.

ReISCHÜTZ, A. 2000. Die Molluskenfauna der Sarmatschichten von Hautzendorf (Weinviertel, Niederösterreich). Nachrichtenblatt der Ersten Vorarlberger Malakologischen Gesellschaft 8, 21-27.

Rendoš, M., ČEJKA, T., ŠTEFFEK, J. \& Mock, A. 2014. Land snails from subterranean traps exposed in a forested scree slope (Western Carpathians, Slovakia). Folia Malacologica 22, 255-261. DOI 10.12657/folmal.022.022

Reuse, C. 1983. On the taxonomic significance of the internal shell in the identification of European slugs of the families Limacidae and Milacidae (Gastropoda, Pulmonata). Biologisch Jaarboek (Dodonaea) 51, 180-200.

Reuss, A.E. 1849. Beschreibung der fossilen Ostracoden und Mollusken der tertiären Süsswasserschichten des nördlichen Böhmens. In Reuss, A.E. \& MeYer, H. von (eds) Die tertiären Süßwassergebilde des nördlichen Böhmen's und ihre fossilen Thierreste. Palaeontographica 2, 16-43.

Reuss, A.E. 1861. Die fossilen Mollusken der tertiären Süsswasserkalke Böhmens. Sitzunsberichte der Kaiserlichen Akademie der Wissenschaften, mathematisch-naturwissenschaftliche Klasse 42, 55-84.
Reuss, A.E. 1868. Paläontologische Beiträge (Zweite Folge.) 5. Über einen neuen fossilen Limax. Sitzungsberichte der Kaiserlichen Akademie der Wissenschaften 57, 79-109.

Rotarides, M. 1925. Sarmatische Landschnecken des Réz-Gebirges im Komitate Bihar. Annales Musei Nationalis Hungarici 22, 127-141.

RunDELL, R.J. 2008. Cryptic diversity, molecular phylogeny and biogeography of the rock- and leaf litter-dwelling land snails of Belau (Republic of Palau, Oceania). Philosophical Transactions of the Royal Society B 363, 3401-3412.

DOI 10.1098/rstb.2008.0110

RyZIEwICZ, Z. 1961. A Tapir tooth from Nowa Wies Krolewska at Opole (Poland). Acta Palaeontologica Polonica 6, 331-338.

RzeBiK-Kowalska, B. 2005. Poland. In VAn den Hoek Ostende, L.W., Doukas, C.S. \& Reumer, J.W.F. (eds) The Fossil Record of the Eurasian Neogene Insectivores (Erinaceomorpha, Soricomorpha, Mammalia), Part I. Scripta Geologica Special Issue 5, 119-134.

Sacco, F. 1884. Nuove specie fossili di molluschi lacustri e terrestri in Piemonte. Atti della Reale Accademia delle Scienze di Torino 19, 247-264.

SACCO, F. 1886. Fauna malacologica delle alluvioni plioceniche del Piemonte. Memorie della regia Accademia delle Scienze di Torino, Classe di Scienze fisiche matematiche naturali, Serie II 37, 169-206.

SACCO, F. 1889. Aggiunte alla fauna malacologica estramarina fossile del Piemonte e della Liguria. Memorie della Reale Accademia delle Scienze di Torino 39, 61-98.

SACCO, F. 1896. I molluschi dei terreni terziarii del Piemonte e della Liguria. Part 20: Caecidae, Vermetidae, Siliquariidae, Phoridae, Calyptraeidae, Capulidae, Hipponycidae, Neritidae e Neritopsidae. 65 pp. Clausen, Torino.

SAlvADOR, R.B. 2013. The fossil pulmonate snails of Sandelzhausen (Early/Middle Miocene, Germany): Succineidae, Testacelloidea and Helicoidea. Zootaxa 3721(2), 157-171. DOI 10.11646/zootaxa.3721.2.3

SALVADOR, R.B. 2014. The fossil land and freshwater snails of Gündlkofen (Middle Miocene, Germany). Zootaxa 3785(2), 271-287. DOI 10.11646/zootaxa.3785.2.9

SAlVADOR, R.B. 2015. The fossil pulmonate snails of Sandelzhausen (Early/Middle Miocene, Germany): Ellobiidae, Pupilloidea, and Clausilioidea. Paläontologische Zeitschrift 89, 37-50. DOI 10.1007/s12542-013-0210-4

Salvador, R.B. \& Rasser, M.W. 2014. The fossil pulmonate snails of Sandelzhausen (Early/Middle Miocene, Germany) (Hygrophila, Punctoidea and limacoids). Archiv fur Molluskenkunde 143(2), 187-202.

DOI 10.1127/arch.moll/1869-0963/143/187-202

SALVADOR, R.B. \& RASSER, M.W. 2016a. Fossil land and freshwater gastropods from the Middle Miocene of Bechingen and Daugendorf, southwestern Germany. Archiv für Molluskenkunde 145(1), 111-124.

DOI 10.1127/arch.moll/1869-0963/145/111-124

SAlVADOR, R.B. \& RASSER, M.W. 2016b. The fossil land and freshwater snails of Oggenhausen (Middle Miocene, Germany). Revista Brasileira de Paleontologia 19(1), 41-52. DOI 10.4072/rbp.2016.1.04

SAlvador, R.B., HöltKe, O. \& Rasser, M.W. 2017. Fossil land and freshwater gastropods from the Miocene of 
Hohenmemmingen, Germany. Palaeodiversity 10(1), 41-48. DOI 10.18476/pale.v10.a4

Salvador, R.B., HöltKe, O., Rasser, M.W. \& Kadolsky, D. 2016a. Annotated type catalogue of the continental fossil gastropods in the Staatliches Museum für Naturkunde Stuttgart, Germany. Palaeodiversity 9, 15-70. DOI 10.18476/pale.v9.a3

Salvador, R.B., Pippèrr, M., Reichenbacher, B., Rasser, M.W. 2016c. Early Miocene continental gastropods from new localities of the Molasse Basin in southern Germany. Paläontologische Zeitschrift 90(3), 469-491.

DOI 10.1007/s12542-016-0291-y

Salvador, R.B., Prieto, J., Mayr, C. \& Rasser, M.W. 2016 b. New gastropod assemblages from the Early/Middle Miocene of Riedensheim and Adelschlag-Fasanerie, southern Germany. Neues Jahrbuch für Geologie und Palaontologie, Abhandlungen 279(2), 127-154.

DOI 10.1127/njgpa/2016/0546

SAlvadoR, R.B., RAsSER, M.W. \& HöLtKe, O. 2015. Fossil gastropods from Miocene Lake Randeck Maar and its hinterland (SW Germany). Neues Jahrbuch für Geologie und Paläontologie, Abhandlungen, 277(3), 251-273.

DOI 10.1127/njgpa/2015/0505

SANDBERGER, F. 1858-1863. Die Conchylien des Mainzer Tertiärbeckens. Heft 1: pp. 1-40, pl. 1-5 (1858), Heft 2: pp. 41-72, pl. 6-10 (1858), Heft 3: pp. 73-112, pl. 11-15 (1859), Heft 4: pp. 113-152, pl. 16-20 (1860), Heft 5-6: pp. 153-232, pl. 21-30 (1861), Heft 7: pp. 233-270, pl. 31-35 (1862), Heft 8: pp. 283-468 (1863). C.W. Kreidel, Wiesbaden.

SANDBERGER, F. 1870-1875. Die Land- und SüsswasserConchylien der Vorwelt. Heft 1-3: pp. 1-96, pl. 1-12 (1870); Heft 4-5: pp. 97-160, pl. 13-20 (1871); Heft 6-8: pp. 161-256, pl. 21-32 (1872); Heft 9-10: pp. 257-352, pl. 33-36 (1873); Heft 11: pp. i-viii + 353-1000 (1875). C.W. Kreidel, Wiesbaden.

SAY, T. 1817. Descriptions of new species of Land and Fresh Water Shells of the United States. Journal of the Academy of Natural Sciences in Philadelphia 1817, ser. 1 1, 123-125.

SAY, T. 1821. Descriptions of univalve shells of the United States. Journal of the Academy of Natural Sciences of Philadelphia ser. 2 1, 149-179.

SAY, T. 1822. Description of univalve terrestrial and fluviatile shells of the United States. Journal of the Academy of Natural Sciences of Philadelphia 2, 370-381.

Schileyko, A.A. 2003. Treatise on Recent Terrestrial Pulmonate Molluscs. Part 10: Ariophantidae, Ostracolethidae, Ryssotidae, Milacidae, Dyakiidae, Staffordiidea, Gastrodontidae, Zonitidae, Daudebardiidae, Parmacellidae. Ruthenica, Supplement 2, 1309-1466.

SchlickuM, W.R. 1974. Zur miozänen Süßwassergastropodenfauna der Rhön. Archiv für Molluskenkunde 104, 69-71.

Schlickum, W.R. 1975. Die oberpliozäne Molluskenfauna von Cessey-sur-Tille (Departement Côte d'Or). Archiv für Molluskenkunde 106, 47-79.

SChLickum, W.R. 1976. Die in der pleistozänen Gemeindekiesgrube von Zwiefaltendorf a.D. Donau abgelagerte Molluskenfauna der Silvanaschichten. Archiv für Molluskenkunde 107, 1-31.
Schlickum, W.R. 1978. Zur oberpannonen Molluskenfauna von Öcs, I. Archiv für Molluskenkunde 108(4-6), 245-261.

SChlickum, W.R. 1979a. Die Gattung Hydrocena im europäischen Tertiär (Neritacea: Hydrocenidae). Archiv für Molluskenkunde 110, 71-73.

SCHLICKUM, W.R. 1979b. Zur oberpannonen Molluskenfauna von Öcs, II. Archiv für Molluskenkunde 109(4-6), 407-415.

Schlickum, W.R. \& Strauch, F. 1975. Zur Systematik westeuropäischer Zonitidae. Archiv für Molluskenkunde 106, 39-45.

SchmidT, A. 1855. Der Geschlechtsapparat des Stylommatophoren in taxonomischer Hinsicht gewürdigt. Abhandlungen des naturwissenschaftlichen Vereins für Sachsen $u$. Thüringen in Halle 1, 1-52.

SChNABEL, T. 2006. Die känozoischen Filholiidae Wenz 1923. Teil 3: Die miozänen Vertreter der Gattung Triptychia (Gastropoda, Pulmonata, Clausilioidea). Archiv für Molluskenkunde 135, 133-203.

DOI 10.1127/arch.moll/0003-9284/135/133-203

SCHNEIDER, S. \& PRIETO, J. 2011. First record of an autochthonous community of fluviatile freshwater molluscs from the Middle/Late Miocene Upper Freshwater Molasse (southern Germany). Archiv für Molluskenkunde 140(1), 1-18. DOI 10.1127/arch.moll/1869-0963/140/001-018

SCHÜTT, H. 1967. Die Landschnecken der untersarmatischen Rissoenschichten von Hollabrunn, N.Ö. Archiv für Molluskenkunde 96, 199-222.

ScHÜTT, H. 1994. Neogene Mollusken aus den Tertiärbecken bei Afyon, Türkei. Geologica et Palaeontologica 28, 167-183.

SemPer, O. 1865. Notice préliminaire sur la famille des Diplommatinacées. Journal de Conchyliologie 13, 289-294.

Shevenell, A.E., Kennett, J.P. \& LeA, D.W. 2004. Middle Miocene southern ocean cooling and Antarctic cryosphere expansion. Science 305, 1766-1770. DOI 10.1126/science. 1100061

Slavík, A. 1869. IV. Neuer Beitrag zur Kenntnis der tertiären Süsswasserkalkschichten von Tuchořic, 260-275. In FRIČ, A. (ed.) Paläontologisch-geologische Notizen betreffend einige Fundorte in dem Gebiete der metamorphischen, tertiären und quaternären Formationen. Archiv für naturwissenschaftliche Landesdurchforschung von Böhmen 1/2.

Soós, I. 1934. The Pontic molluscan fauna of Öcs. Allattani Közlemények 31, 183-203.

Stabile, G. 1859. Prospetto sistematico-statistico dei molluschi terrestri e fluviatili viventi nel territorio di Lugano (Svizzera italiana). Atti della Societŕ Geologica residente in Milano 1, 127-189.

Steenberg, C.M. 1917. Anatomie des Acanthinula et des Vallonia. Les organs genitaux. Videnskabelige Meddelelser fra Dansk Naturhistorisk Forening Kobenhaven 9, 1-15.

Steenberg, C.M. 1925. Études sur l'anatomie et la systématique des maillots (Fam. Pupillidae s. lat.). Videnskabelige Meddelelser fra Dansk naturhistorisk Forening i Kjøbenhavn $80,1-215$.

Steklov, A.A. 1966. Nazemnye molluski neogena Predkavkaza i ich stratigrafitsjeskoje znatsjenije. 262 pp. Akademia Nauka S.S.S.R., Moskva. [in Russian]

Sterki, V. 1892. Preliminary list of North American Pupidae (North of Mexico). The Nautilus 6(1), 2-8.

Sterki, V. 1893. Bifidaria: a new subgenus of Pupa. The Nautilus 6(9), 99-101. 
STIMPSON, W. 1865. Researches upon the Hydrobiinae and allied forms; chiefly made upon materials in the Museum of the Smithsonian Institution. Smithsonian Miscellaneous Collections 7, 201, 1-59.

StRAuCh, F. 1977. Die Entwicklung der europäischen Vertreter der Gattung Carychium O.F. Müller seit dem Miozän. Archiv für Molluskenkunde 107, 149-193.

STRøM, H. 1765. Beskrivelse over Norske insecter, første stykke. Det Trondhiemske Selskabs Skrifter 3, 376-439.

Studer, S. 1789. Class VI. Vermes. Ordo III. Testacea, 384-392. In Coxe, W. (ed.) Travels in Switzerland, in a series of letters to William Melmoth, Esq. In three volumes. Vol. III. Cadell, London.

Studer, S. 1820. Kurzes Verzeichniss der bis jetzt in unserm Vaterlande entdeckten Conchylien. Naturwissenschaftlicher Anzeiger der Allgemeinen Schweizerischen Gesellschaft für die Gesammten Naturwissenschaften 3, 83-90, 91-94.

Stworzewicz, E. 1995. Miocene land snails from Belchatow (Central Poland), I. Cyclophoridae, Pomatiasidae (Gastropoda Prosobranchia). Paläontologische Zeitschrift 69, 19-30. DOI 10.1007/BF02985971

Stworzewicz, E. 1999a. Miocene land snails from Bełchatów (Central Poland), III: Carychiinae (Gastropoda; Pulmonata: Ellobiidae). Paläontologische Zeitschrift 73, 261-276. DOI 10.1007/BF02988039

Stworzewicz, E. 1999b. Miocene land snails from Bełchatów (Central Poland). IV. Pupilloidea (Gastropoda, Pulmonata). Systematics, biostratigraphic and paleoecological studies. Folia Malacologica 7, 133-170. DOI 10.12657/folmal.007.015

Stworzewicz, E. \& Prisyazhnyuk, V.A. 1997. Helicodiscus (Helicodiscus) depressus (Eichwald, 1830) or Helicodiscus (Helicodiscus) parallelus (Say, 1821) (Gastropoda Pulmonata: Endodontidae) in the Neogene of Europe? Genus 8, 197-204.

StworZewicz, E. \& SoŁtys, Z. 1996. Miocene land snails from Bełchatów (Central Poland). II: Aciculidae (Gastropoda Prosobranchia). Paläontologische Zeitschrift 70, 67-77. DOI 10.1007/BF02988269

Stworzewicz, E. \& Szynkiewicz, A. 1988. Miocenskie ślimaki lądowe we wschodniej części odkrywki KWB Bełchatów. Geological Quarterly 32, 655-652.

Stworzewicz, E., Prisyazhnyuk, V.A. \& Górka, M. 2013. Systematic and palaeoecological study of Miocene terrestrial gastropods from Zwierzyniec (southern Poland). Annales Societatis Geologorum Poloniae 83, 179-200.

SZYNDLAR, Z. 1991. A review of Neogene and Quaternary snakes of central and eastern Europe. Part 11: Natricinae, Elapidae, Viperidae. Estudios Geológicos 47, 237-266. DOI 10.3989/egeol.91473-4422

THIELE, J. 1931. Handbuch der systematischen Weichtierkunde, 1. 377-778 pp. Fischer, Jena.

Tномё, C. 1845. Fossile Conchylien aus den Tertiärschichten bei Hochheim und Wiesbaden, gesammelt und im naturhistorischen Museum zu Wiesbaden aufgestellt. Jahrbücher des Vereins für Naturkunde im Herzogthum Nassau 2, 125-162.

Tongkerd, P., Sutcharit, C. \& Panha, S. 2013. Two New Species of Micro Land Snails from Two Islands in the Andaman
Sea (Prosobranchia: Diplommatinidae; Pulmonata: Pupillidae). Tropical Natural History 13, 65-76.

Troll, O.R. voN 1907. Die pontischen Ablagerungen von Leobersdorf und ihre Fauna. Jahrbuch der Geologischen Reichsanstalt 57, 33-90.

Troll-Obergfell, O.R. von 1944. Eine tortone Landschneckenablagerung bei St. Veit an der Triesting (Stadtgemeinde Berndorf). Mitteilungen des Alpenländischen geologischen Vereines (Mitteilungen der geologischen Gesellschaft in Wien) 35, 383-385.

Troschel, F.H. 1857. Das Gebiss der Schnecken, zur Begründung einer natürlichen Classification, 1. 73-112 pp. Nicolai, Berlin.

Tryon, G.W. 1866. Monograph of the terrestrial Mollusca of the United States. American Journal of Conchology 2, 306-327.

Van Benthem Jutting, W.S.S. 1950. Systematic studies on the non-marine Mollusca of the Indo-Australian Archipelago. II. Critical revision of the Javanese pulmonate land-shells of the Families Helicarionidae, Pleurodontidae, Fruticicolidae and Streptaxidae. Treubia 20, 381-505.

VAn Benthem Jutting, W.S.S. 1959. Catalogue of the non-marine Mollusca of Sumatra and of its satellite islands. Beaufortia 7, 41-191.

VAvrová, L., Horsák, M., ŠTeFeK, J. \& ČEJKA, T. 2009. Ecology, distribution and conservation of Vertigo species of European Importance in Slovakia. Journal of Conchology 40, 1-12.

VERMEULEN, J.J. 1997. Notes on some terrestrial molluscs of Bali. Basteria 61, 57-60.

Vermeulen, J.J., Liew, T.S. \& Schilthuizen, M. 2015. Additions to the knowledge of the land snails of Sabah (Malaysia, Borneo), including 48 new species. ZooKeys 531, 1-139. DOI 10.3897/zookeys.531.6097

Villa, A. \& Villa, J.B. 1841. Dispositio Systematica Conchyliarum Terrestrium et Fluviatilium quae adservantur in collectione fratrum Ant. et Jo. Bapt. Villa, conspectu abnormitatum novarumque specierum descriptionibus adjectis. 62 pp. Borroni et Scotti, Mediolani. DOI 10.5962/bhl.title.137439

WAGNER, A. 1922. Beiträge zur Molluskenfauna Zentraleuropas. Annales Zoologici Musei Polonici Historiae Naturalis 1(2/3), $112-123$.

WAGNER, H. 1935. Diagnosen neuer Limaciden aus dem Naturhistorischen Museum in Wien. Zoologischer Anzeiger 95, 174.

WAgner, M. \& Matl, K. 2007. Stratygrafia kredy jezionej ze złoża węgla brunatnego „Szeczerców“. Geologia 33(3), 289-315.

WALKer, B. 1903. Notes on eastern American Ancyli. The Nautilus 17(2/3), 13-19, 25-31. DOI 10.5962/bhl.part.18318

Watson, H. 1920. The affinities of Pyramidula, Patulastra, Acanthinula and Vallonia. Proceedings of the Malacological Society of London 14(1), 6-30.

Watson, H. \& VerdCourt, B.J. 1953. The two British species of Carychium. Journal of Conchology 23, 306-324.

Webster, N.B., Van Dooren, T.J.M. \& Schilthuizen, M. 2012. Phylogenetic reconstruction and shell evolution of the Diplommatinidae (Gastropoda: Caenogastropoda). Molecular Phylogenetics and Evolution 63, 625-638.

DOI 10.1016/j.ympev.2012.02.004 
Wegner, R.N. 1908. Zur Kenntnis der Säugetierfauna des Obermiocäns bei Oppeln (Oberschlesien). Verhandlungen der Kaiserlich-Königlichen. Geologischen Reichsanstalt 1908, 111-117.

WegNER, R.N. 1913. Tertiär und umgelagerte Kreide bei Oppeln (Oberschlesien). Palaeontographica 60(3-4), 175-274.

Welter-Schultes, F. 2012. European non-marine molluscs, a guide for species identification. 674 pp. Planet Poster Editions, Göttingen.

Wenz, W. 1914. Paläontologischer Teil, 30-154. In Fischer, K. \& Wenz, W. (eds) Die Landschneckenkalke des Mainzer Beckens und ihre Fauna. Jahrbücher des Nassausischen Vereins für Naturkunde 67.

Wenz, W. 1915. Die fossilen Arten der Gattung Strobilops Pilsbry und ihre Beziehungen $\mathrm{zu}$ den lebenden. Neues Jahrbuch für Mineralogie, Geologie und Paläontologie 1915(2), 63-88.

WenZ, W. 1916. Die Öpfinger Schichten der schwäbischen Rugulosakalke und ihre Beziehung $\mathrm{zu}$ anderen Tertiärablagerungen. Jahresberichte und Mitteilungen des oberrheinischen geologischen Vereins, N.F. 5(2), 162-196.

WENZ, W. 1919. Zur Systematik tertiärer Land- und Süßwassergastropoden. Nachrichtsblatt der deutschen Malakozoologischen Gesellschaft 51, 76-79.

WeNZ, W. 1921. Zur Fauna der pontischen Schichten von Leobersdorf. Senckenbergiana 1, 23-33, 75-86.

WENZ, W. 1922a. Eine neue Lauria aus dem Obermiocän von Steinheim am Aalbuch. Archiv für Molluskenkunde 54, 106-109.

Wenz, W. 1922b. Das Tertiär im Vogelsberg und seine Beziehungen $\mathrm{zu}$ dem der Wetterau und $\mathrm{zu}$ anderen Tertiärablagerungen. Wetterauische Gesellschaft für die gesamte Naturkunde zu Hanau 1909-1922, 1-82

WenZ, W. 1923-1930. Fossilium Catalogus I: Animalia. Gastropoda extramarina tertiaria. Pars 17: pp. 1-352 (1923); Pars 18: 353-736 pp. (1923); Pars 20: pp. 737-1068 (1923); Pars 21: pp. 1069-1420 (1923); Pars 22: pp. 1421-1734 (1923); Pars 23: 1735-1862 pp. (1923); Pars 32: 1863-2230 pp. (1926); Partes 40, 43 et 46: 3015-3387 pp. (1930). W. Junk, Berlin.

Wenz, W. 1927. Weitere Beiträge zur Fauna der pontischen Schichten von Leobersdorf. Senckenbergiana 9, 41-48.

Wenz, W. 1935. Weitere Beiträge zur Land- und Süßwasser-Molluskenfauna der subalpinen Molasse des Pfändergebietes. Senckenbergiana 17, 223-225.

Wenz, W. \& Edlauer, A. 1942. Die Molluskenfauna der oberontischen Süßwassermergel vom Eichkogel bei Mödling, Wien. Archiv für Molluskenkunde 74, 82-98.

WESTERLund, C.A. 1885. Fauna der in der paläarctischen Region (Europa, Kaukasien, Sibirien, Turan, Persien, Kurdistan, Armenien, Mesopotamien, Kleinasien, Syrien, Arabien, Egypten, Tripolis, Tunesien, Algerien und Marocco) lebenden Binnenconchylien. V. Fam. Succinida, Auriculido, Limnoeidce, Cyclostomidce \& Hydrocenidce. 135 pp. Håkan Ohlsson, Lund.

WeSTERLUnd, C.A. 1887. Fauna der in der paläarctischen Region (Europa, Kaukasien, Sibirien, Turan, Persien, Kurdistan, Armenien, Mesopotamien, Kleinasien, Syrien, Arabien, Egypten, Tripolis, Tunesien, Algerien und Marocco) lebenden
Binnenconchylien. III. Gen. Buliminus, Sesteria, Pupa, Stenogyra \& Cionella. $183+15$ pp. Håkan Ohlsson, Lund.

Westerlund, C.A. 1902. Methodus dispositionis conchyliorum extramarinorum in Regione palaearctica viventium, familias, genera, subgenera, et stirpes sistens. Rad Jugoslavenske Akademije Znanosti i Umjetnosti, Matematičko-Prirodoslovni Razred 151(32), 82-139.

WikTor, A. 1981. Genus-group level classification of Milacidae (Gastropoda, Pulmonata). Malakologische Abhandlungen 7(15), 145-153.

Wiktor, A. \& Likharev, I.M. 1979. Phylogenetische Probleme bei Nacktschnecken aus den Familien Limacidae und Milacidae (Gastropoda, Pulmonata). Malacologia 18, 123-131.

WinkLER-Hermaden, A. 1952. Über neue Ergebnisse aus dem Tertiärbereich des steirischen Beckens und über das Alter der oststeirischen Basaltausbrüche. Sitzungsberichte der österreichischen Akademie der Wissenschaften, mathematischnaturwissenschaftliche Klasse 160, 1-15.

Winter, A.J. De, van Leeuwen, A. \& Hovestadt, A. 2016. A new species of Glyphyalus (Gastropoda, Pulmonata, Oxychilidae) from the Dutch Caribbean island of St. Eustatius. Basteria 80, 39-46.

WolfF, J.F. 1800-1811. Icones Cimicum descriptionibus illustratae. Fasciculus quintus et ultimus. viii + 167-214 pp. Johann Jakob Palm, Erlangen.

Wollaston, T.V. 1878. Testacea Atlantica or the land and freshwater shells of the Azores, Madeiras, Salvages, Canaries, Cape Verdes, and Saint Helena. 588 pp. L. Reeve and Co., London

Woodward, B.B. 1903. Note on the date of publication of J. F. Gray's 'Catalogue of Pulmonata in the British Museum. Pt. I', 12mo, 1855; and of A. Moquin-Tandon's 'Histoire naturelle des mollusques terrestres et fluviatles de la France', 2 vols. 1855. Proceedings of the Malacological Society of London 5, 261.

Zachos, J., Pagani, M., Sloan, L., Thomas, E. \& Billups, K. 2001. Trends, rhythms, and aberrations in global climate 65 Ma to present. Science 292, 686-693.

DOI $10.1126 /$ science. 1059412

ZIETEN, C.H. vON 1830-1833. Die Versteinerungen Württembergs, oder naturgetreue Abbildungen der in den vollständigsten Sammlungen, namentlich der in dem Kabinet des Oberamts-Arzt Dr. Hartmann befindlichen Petrefacten, mit Angabe der Gebirgs-Formationen, in welchen dieselben vorkommen und der Fundorte. i-viii + 1-16, Taf. 1-12 (1830); 17-32, Taf. 13-24 (1831); 33-64, Taf. 25-48 (1832); 65-102, Taf. 49-72 (1833). Verlag and Lithographie der Expedition des Werkes unserer Zeit, Stuttgart.

Zilch, A. 1959. Euthyneura. In Schindewolf, O.H. (ed.) Handbuch der Paläozoologie 6. 834 pp. Bornträger, Berlin-Zehlendorf.

ZiLCH, A. 1976. Die Typen und Typoide des Natur-Museums Senckenberg, 56: Mollusca: Aciculidae. Archiv für Molluskenkunde 107, 123-136.

ZiLCH, A. 1978. Die Typen und Typoide des Natur-Museums Senckenberg, 59. Mollusca: Triptychiidae und Clausiliidae (Nachträge zu Teil 12). Archiv für Molluskenkunde 108, 267-298. 